\title{
OBSERVATIONS AT CONVERGENT MARGINS CONCERNING SEDIMENT SUBDUCTION, SUBDUCTION EROSION, AND THE GROWTH OF CONTINENTAL CRUST
}

\author{
Roland von Huene \\ GEOMAR, Kiel, Germany
}

\author{
David W. Scholl \\ U.S. Geological Survey \\ Menlo Park, California
}

\begin{abstract}
At ocean margins where two plates converge, the oceanic plate sinks or is subducted beneath an upper one topped by a layer of terrestrial crust. This crust is constructed of continental or island arc material. The subduction process either builds juvenile masses of terrestrial crust through arc volcanism or new areas of crust through the piling up of accretionary masses (prisms) of sedimentary deposits and fragments of thicker crustal bodies scraped off the subducting lower plate. At convergent margins, terrestrial material can also bypass the accretionary prism as a result of sediment subduction, and terrestrial matter can be removed from the upper plate by processes of subduction erosion. Sediment subduction occurs where sediment remains attached to the subducting oceanic plate and underthrusts the seaward position of the upper plate's resistive buttress (backstop) of consolidated sediment and rock. Sediment subduction occurs at two types of convergent margins: type 1 margins where accretionary prisms form and type 2 margins where little net accretion takes place. At type 2 margins $(\sim 19,000 \mathrm{~km}$ in global length), effectively all incoming sediment is subducted beneath the massif of basement or framework rocks forming the landward trench slope. At accreting or type 1 margins, sediment subduction begins at the seaward position of an active buttress of consolidated accretionary material that accumulated in front of a starting or core buttress of framework rocks. Where small-to-mediumsized prisms have formed $(\sim 16,300 \mathrm{~km})$, approximately $20 \%$ of the incoming sediment is skimmed off a detachment surface or decollement and frontally accreted to the active buttress. The remaining $80 \%$ subducts beneath the buttress and may either underplate older parts of the frontal body or bypass the prism entirely and underthrust the leading edge of the margin's rock framework. At margins bordered by large prisms $(\sim 8,200 \mathrm{~km})$, roughly $70 \%$ of the incoming trench floor section is subducted beneath the frontal accretionary body and its active buttress. In rounded figures the contemporary rate of solid-volume sediment subduction at convergent ocean margins $(-43,500 \mathrm{~km})$ is calculated to be $1.5 \mathrm{~km}^{3} / \mathrm{yr}$. Correcting type 1 margins for high rates of terrigenous seafloor sedimentation during the past $30 \mathrm{~m} . \mathrm{y}$. or so sets the long-term rate of sediment subduction at $1.0 \mathrm{~km}^{3} / \mathrm{yr}$. The bulk of the subducted material is derived directly or

indirectly from continental denudation. Interstitial water currently expulsed from accreted and deeply subducted sediment and recycled to the ocean basins is estimated at $0.9 \mathrm{~km}^{3} / \mathrm{yr}$. The thinning and truncation caused by subduction erosion of the margin's framework rock and overlying sedimentary deposits have been demonstrated at many convergent margins but only off northem Japan, central Peru, and northem Chile has sufficient information been collected to determine average or long-term rates, which range from 25 to $50 \mathrm{~km}^{3} / \mathrm{m}$.y. per kilometer of margin. A conservative long-term rate applicable to many sectors of convergent margins is $30 \mathrm{~km}^{3} / \mathrm{km} / \mathrm{m}$.y. If applied to the length of type 2 margins, subduction erosion removes and transports approximately $0.6 \mathrm{~km}^{3} / \mathrm{yr}$ of upper plate material to greater depths. At various places, subduction erosion also affects sectors of type 1 margins bordered by small- to medium-sized accretionary prisms (for example, Japan and Peru), thus increasing the global rate by possibly $0.5 \mathrm{~km}^{3} / \mathrm{yr}$ to a total of $1.1 \mathrm{~km}^{3} / \mathrm{yr}$. Little information is available to assess subduction erosion at margins bordered by large accretionary prisms. Mass balance calculations allow assessments to be made of the amount of subducted sediment that bypasses the prism and underthrusts the margin's rock framework. This subcrustally subducted sediment is estimated at $0.7 \mathrm{~km}^{3} / \mathrm{yr}$. Combined with the range of terrestrial matter removed from the margin's rock framework by subduction erosion, the global volume of subcrustally subducted material is estimated to range from 1.3 to $1.8 \mathrm{~km}^{3} / \mathrm{yr}$. Subcrustally subducted material is either returned to the terrestrial crust by arc-related igneous processes or crustal underplating or is lost from the crust by mantle absorption. Geochemical and isotopic data support the notion that upper mantle melting returns only a small percent of the subducted material to the terrestrial crust as arc igneous rocks. Limited areal exposures of terrestrial rocks metamorphosed at deep ( $>20-30 \mathrm{~km})$ subcrustal pressures and temperatures imply that only a small fraction of subducted material is reattached via deep crustal underplating. Possibly, therefore much of the subducted terrestrial material is recycled to the mantle at a rate near $1.6 \mathrm{~km}^{3} / \mathrm{yr}$, which is effectively equivalent to the commonly estimated rate at which the mantle adds juvenile igneous material to the Earth's layer of terrestrial rock.
\end{abstract}




\section{INTRODUCTION AND BACKGROUND PERSPECTIVES}

Terrestrial crust, which is constructed of continental and island arc rocks, is amassed at convergent ocean margins [see Kay, 1980; Dewey and Windley, 1981; Reymer and Schubert, 1984; Taylor and McLennan, 1985; Howell, 1989a; Ashwal, 1989]. Convergent ocean margins are plate boundaries at which the oceanic or lower plate is subducted beneath the upper plate. The top of the upper plate is typically a $20-40 \mathrm{~km}$ thick layer of terrestrial rocks (Figure 1). At the subduction zones, arc igneous rocks contributed from the underlying mantle add juvenile material to the layer of terrestrial rocks. Arc magmatism is probably the most important process sustaining the Earth's stock of terrestrial matter [Reymer and Schubert, 1984].

It is also widely recognized that tectonic processes at convergent margins constantly fashion new regions of continental crust from fragments of older or preexisting crustal material [Helwig, 1974; Coney et al., 1980; Howell, 1989a]. These assemblages form because some of the igneous, sedimentary, and thicker crustal masses attached to the underthrusting oceanic plate are mechanically scraped off and accreted to the seaward edge of the upper terrestrial plate (Figure 1). The process of forming such an accretionary complex (or prism or wedge) is commonly referred to as subduction accretion. Hamilton [1988], Bickford [1988], and Howell [1989a] have recently reviewed key observations and thinking concerning accretionary tectonism and also the associated lateral or sideways movement of terranes that is part of the assembly process at ocean margins [see Beck, 1983, 1986].

Notwithstanding the attention given to processes of juvenile crustal growth and terrane accumulation, it has long been recognized that other subduction processes act at convergent margins to either remove or fail to store rock and sedimentary masses [Gilluly, 1963]. These processes, which, respectively, involve sediment subduction and subduction erosion [Scholl et al., 1980], can retard or thwart continental growth. Subduction erosion can also truncate the seaward edges of accretionary bodies and ancient continental masses [Scholl et al., 1977; Ziegler et al., 1981; Scholl and Vallier, 1981]. In this paper we review and reflect on the implications of relatively recently acquired marine geological and geophysical data concerning the processes of sediment subduction and subduction erosion. We estimate contemporary and long-term rates of subduction of terrestrial material. We note in particular that during the latter part of Earth's history the volume of deep or subcrustally subducted material potentially reaching

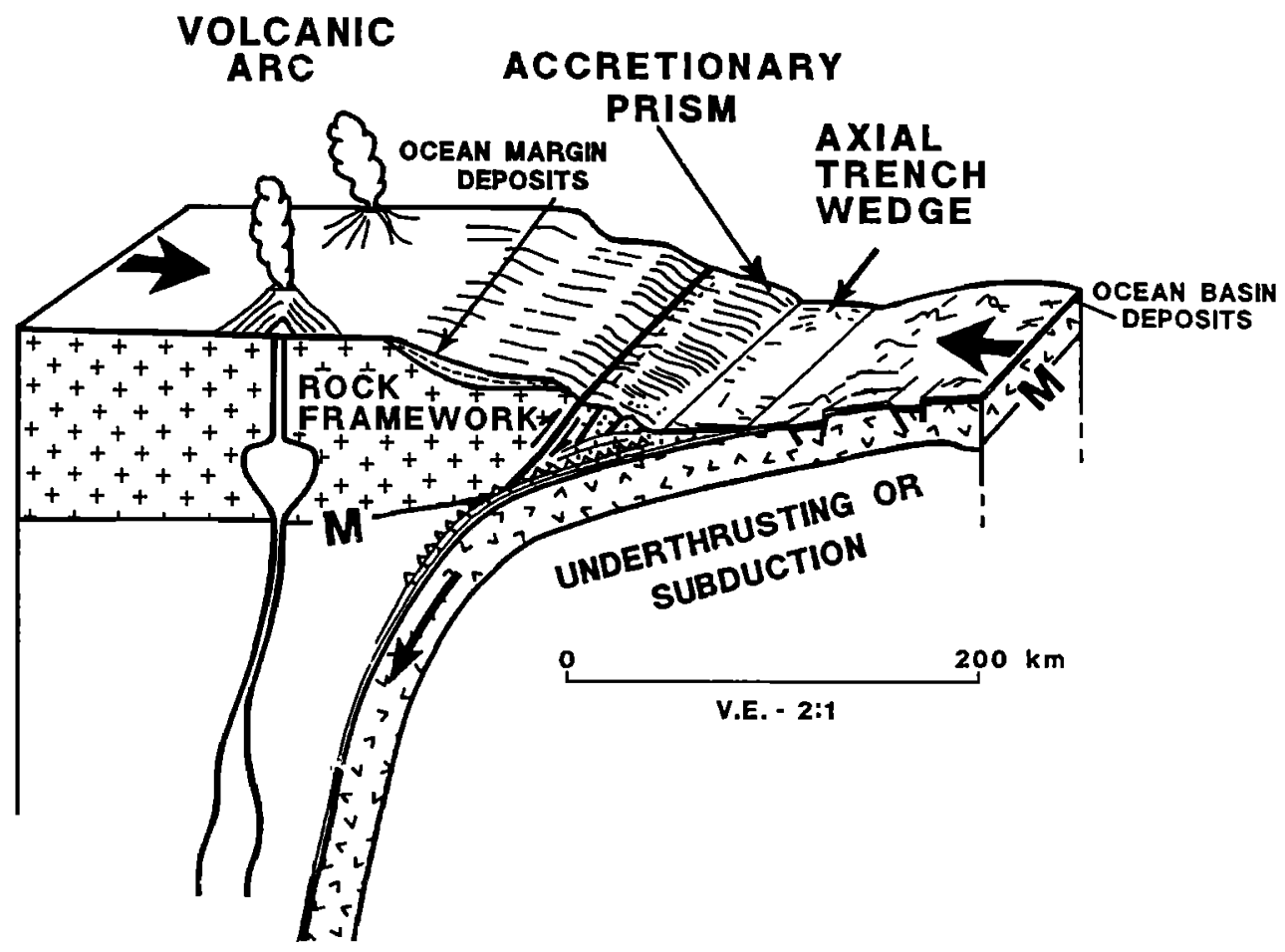

Figure 1. Diagrammatic portrayal of the principal sedimentary deposits and morphologic elements of a convergent ocean margin and the sediment-associated subduction processes operating there. Facing arrows indicate that the continental or terrestrial crust of the upper plate (left) converges orthogonally with the underthrusting oceanic crust of the lower plate. Seaward of the margin's framework rock, the process of subduction accretion has formed a small accretionary pile or prism of offscraped trench floor deposits. The companion process of sediment subduction is shown conveying trench and ocean basin deposits beneath the seaward base of the framework and potentially to mantle (M) depths. Diagram is only roughly to scale. 
mantle depths effectively equals the best estimates of the addition of juvenile igneous masses to the layer of terrestrial rocks [Kay, 1980; Dewey and Windley, 1981; Reymer and Schubert, 1984; Howell, 1989a].

\section{BACKGROUND PERSPECTIVE}

Convergent margins are dynamic plate boundaries characterized geomorphically by deep ocean trenches, seismically by landward dipping zones of earthquakes, tectonically by regional-scale crustal faulting and terrane movements, and magmatically by arcuate and linear belts of eruptive centers, the so-called volcanic arc (Figure 1). Vexing to many [see Scholl et al., 1970; von Huene and Shor, 1969], in the 1960's and early 1970's the recognition of structures diagnostic of how subduction processes worked at convergent margins was challenged by the great water depths and steep submarine slopes of the trench environment. These circumstances made it difficult to recover rock samples by conventional dredging and greatly diminished the resolution of the subsurface structures by acoustic imaging techniques then available to most researchers.

Nonetheless, by the mid 70 's, offshore seismic reflection studies had resolved some of the important structural aspects of the accretionary process [Seely et al., 1974; Karig and Sharman, 1975]. Despite these advances, much of the understanding of how subduction accretion operated came from examining ancient accretionary masses exposed in coastal mountain belts, for example, the Franciscan Complex of California [Hamilton, 1969; Ernst, 1970]. But the study of these accretionary complexes provided little insight into inferred and suspected processes that might effect the bypassing of oceanic sediment (subcrustal sediment subduction) and wastage of upper plate material (subduction erosion) [Scholl et al., 1977].

During the past decade, advances in offshore geological and geophysical techniques have made it possible to successfully explore the deep subsurface structures and rock sequences of convergent margins. These advancements include swath-mapping bathymetry, which provides accurate areal images of the morphology of the trench axis region, modem seismic reflection acquisition and processing techniques that resolve subsurface structures with detail and clarity, and deep-sea drilling for scientific purposes that returns samples from nearly a kilometer beneath the deeply submerged landward slopes of trenches.

\section{SEDIMENT SUBDUCTION}

\section{Some History and Definitions}

The general notion that sedimentary masses have been subducted beneath ocean margins arose over the implications of unbalanced volumes in regional sediment budgets, the paucity of oceanic pelagic sediment in exposed subduction complexes, and the small size or virtual absence of accretionary wedges along lengthy sectors of convergent margins. Sketchy histories of these concerns have been presented by Scholl et al. [1980] and Scholl [1987]. One of the first to invoke and illustrate the concept of sediment subduction was Coats [1962], who hypothesized that sediment injected to mantle depths by an underthrusting oceanic crust was needed to account for the geochemistry of volcanic rocks exposed along the Aleutian island arc. Figure $2 a$ is a simplified reproduction of the diagram he used to present his seminal concept.

A.

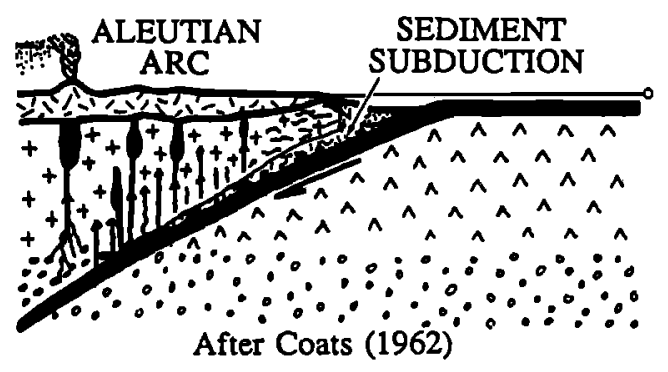

B.
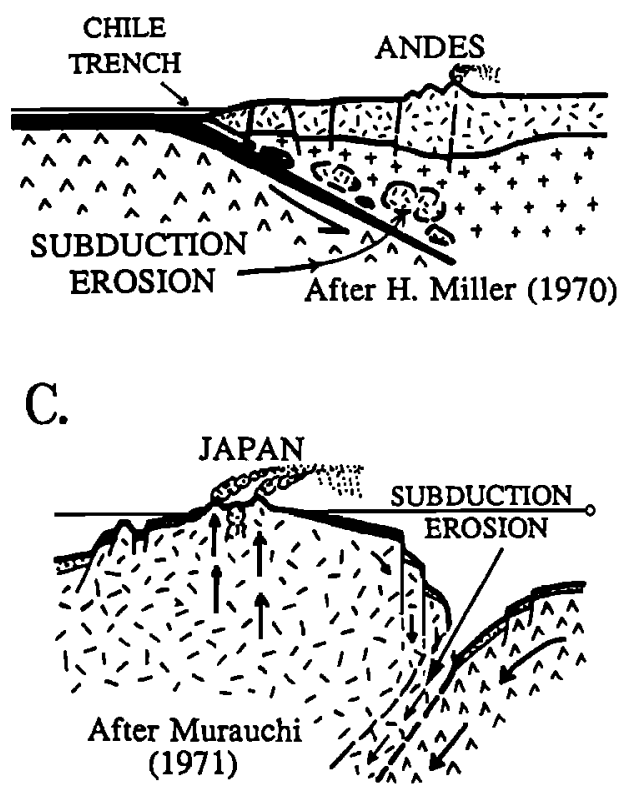

Figure 2. Some of the first published depictions of the processes of sediment subduction and subduction erosion. (a) Coats [1962], well before the plate tectonics paradigm was formulated, conceived that sediment subduction was an essential ingredient in volcanic rocks causing to be erupted along the Aleutian arc. (b) Miller $[1970 a, b]$, nearly a decade later, proposed that subduction can also truncate the rock framework of ocean margins, in his example the structural fabric of metamorphic and igneous rocks underlying the central and northern margin of Chile (see Figure 18). Independently, Murauchi [1971] reasoned that a subduction-related process of tectonic erosion wasted away the continental crustal rocks of the northem Japan margin. 
At convergent ocean margins the lower plate is the principal contributor of input material (Figure 1). The lower plate is constructed of igneous rocks of the oceanic crust and its overlying cover of ocean basin sediment (Figure 3). Ocean basin sediment is composed chicfly of clayey, far-traveled terrigenous or continental detritus contributed by continental erosion, carbonate and siliceous material supplied by planktonic and benthic organism, and metal oxides and ash of volcanogenic origin [Howell and Murray, 1986; Hay et al., 1988]. Far from continents and adjacent to poorly drained landmasses, ocean basin deposits are typically only $200-600 \mathrm{~m}$ thick. This thin sedimentary mantle is commonly referred to as the ocean basin layer of pelagic or hemipelagic deposits.

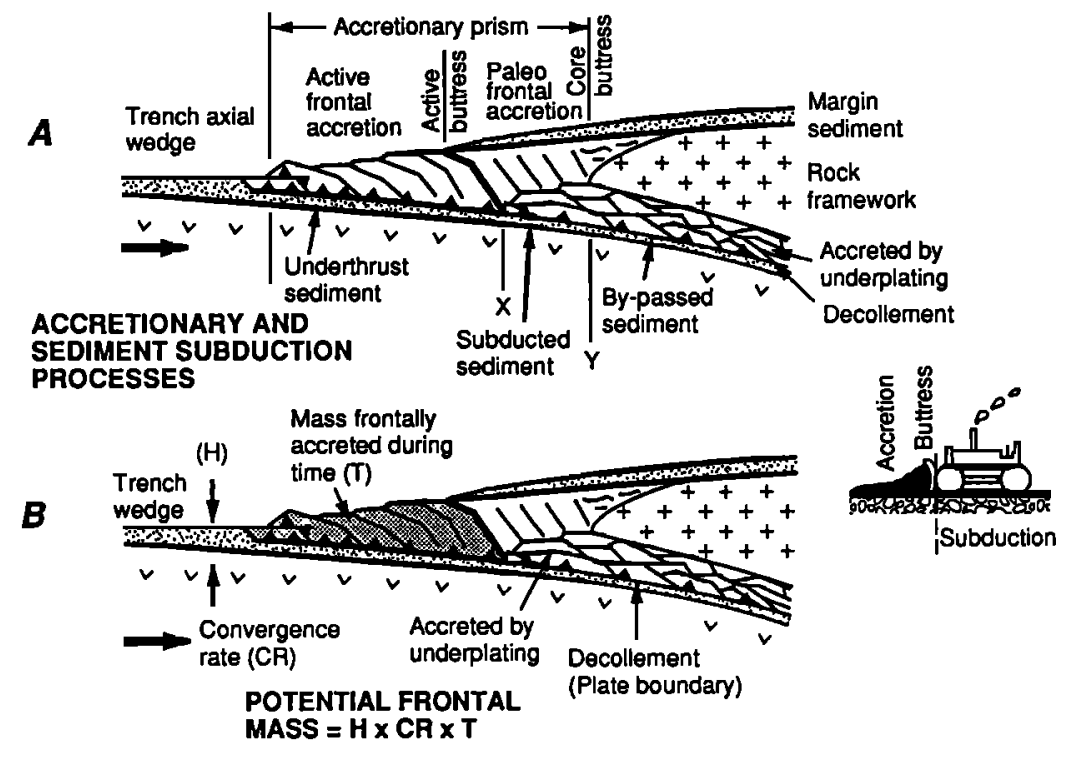

TYPE-2, NON-ACCRETING MARGIN, $(19,000 \mathrm{~km})$
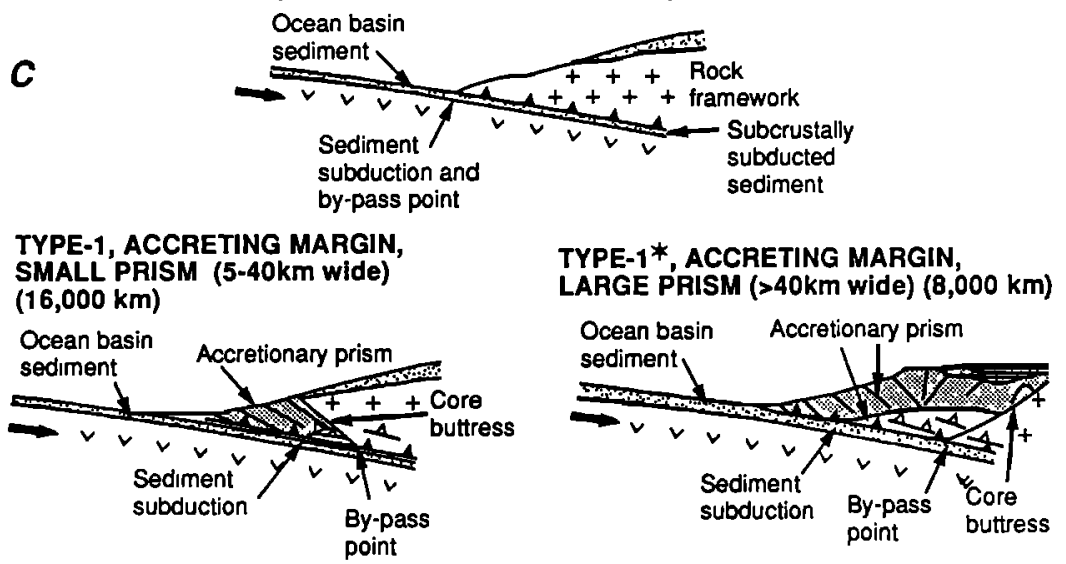

Figure 3. (a) Diagram of accretionary prism and the processes of frontal accretion and underplating that contribute to its volumetric growth. Frontal accretion occurs seaward of an active buttress of structurally strengthened older accretionary material, which was initially added to a core buttress of the margin's bedrock or rock framework. Solid barbs indicate active thrust faults, open barbs indicate less active and inactive thrust faults. Offscraped trench sediment is detached above a decollement, the effective plate boundary, in packets that build the frontal mass by thrust faulting, folding, and tilting against the active buttress, below which ocean sediment is subducted. Once the thrust packets have achieved maximum tilting and shortening, accretion of subducted sediment continues to increase the volume of the prism by processes of underplating, which can extend landward beneath the core buttress. (b) The geophysically measured volume of a frontally accreted body (shaded) when compared to the potential volume of such a mass, which is approximated by the product of the convergent rate (CR), average thickness of incoming trench floor sediment $(H)$, and the time period during which the measured volume accumulated $(T)$, identifies the volume of sediment that is underthrusting the frontal body and has been subducted landward of the active buttress. (c) Simplified diagrams of three types of convergent margins: type 2 or nonaccreting margins, type 1 margins with small to medium-sized prisms, and type $1^{*}$ margins with large accretionary prisms. The approximate global length of these margin types is shown, frontal accretionary masses are shaded. 
Contrastingly, along convergent margins reached by large rivers or drainage systems, ocean basin deposits are dominantly coarser grained sandy and silty units of terrigenous origin. Seaward of the trench the terrigenous blanket, or hemiterrigenous where accompanied by an important biogenic component, attains thicknesses usually greater than $500 \mathrm{~m}$ and, in some areas, as thick as $5-6 \mathrm{~km}$ (for example, Barbados region of the Lesser Antilles) [Biju-Duval et al., 1982; Westbrook et al., 1988; Mascle and Moore, 1990]. Deposition of turbidity current deposits along the trench axis, the axial trench fill or wedge, can also thicken the overall ocean floor section to several kilometers or more. Thick axial wedges are shown diagrammatically on Figures 1 and 3. The accretionary complex that underlies the landward slopes of many trenches is predominantly composed of terrigenous turbidite deposits that have been skimmed off the subducting ocean crust [Karig and Sharman, 1975].

In this paper the accretionary prism refers to the landward thickening wedge-shaped body of oceanic rock and sediment that during a period of time has been added tectonically to the basement or rock framework of an ocean margin (Figures 1 and 4). This framework is commonly constructed of complexes of igneous and metamorphic rock or sequences of deformed sedimentary rock much older than, and not tectonically part of, a growing accretionary mass. The additive mechanisms are those of subduction accretion, which involve the transfer of material from the lower plate to the upper one by frontal accretion and underplating (Figure 3) [Scholl et al., 1980].

Accretionary piles grow volumetrically by the surface process of frontal accretion and by the subsurface process of underplating. The division of these refers to the seaward position of the margin's resistive rock structure or buttress. In front of the buttress the upper part of the oceanic sediment is offscraped by the process of frontal accretion and the lower part is underthrust. Landward and beneath the buttress, oceanic sediment is subducted and subsequently either accreted by underplating or transported on the lower plate to greater depths (Figure $3 a$ ). The resistive buttress is the seawardmost part of the margin's mechanical backstop, which includes the rock framework and the relatively consolidated and tectonically quiescent older parts of the accretionary mass (see also Cloos and Shreve $[1988 a, b])$. Sedimentary deposits a few hundred meters to many kilometers in thickness bury the surface of the buttress mass (Figures 1 and 3).

An often used analogy of frontal accretion and subduction is the blade of earth or snow moving machinery and the behavior of the moved and unmoved medium (Figure 3a) [Helwig and Hall, 1974]. The blade (buttress) dislodges the upper less consolidated medium (sediment) from a lower more consolidated one (consolidated sediment or igneous ocean crust). Against the blade, the upper medium is offscraped into a growing mass of thrust slices (frontal accretion), but part of the medium passes rearward and beneath the blade and is overrun (subduction).
At those convergent margins where accretionary prisms of oceanic sediment effectively do not form, the base of the landward trench slope is the seaward position of the margin's rock framework, which can also serve as a core or starting buttress for an eventual pile of offscraped sediment. Sediment subduction, potentially leading to subcrustal underplating farther landward, begins here (Figure 3c). Small, ephemeral accretionary prisms commonly form in front of such core buttresses. Where larger more permanent accretionary prisms form, the position of the resistive buttress advances seaward as accreting material structurally consolidates in front of the core buttress (Figures $3 a$ and $3 b$ ). Unlike the core buttress the front of the advancing or active buttress is not a static or exact structure but a dynamic one. Its geographic position is determined by the dynamics of the accretionary process and can only be approximately located.

These dynamics are modeled by Platt [1989]. During the beginning of frontal accretion, thrust slices that detach the upper part of the incoming sedimentary section have dimensions determined by sediment strength and thickness. Stacking and upward rotation of the thrust slices thicken and shorten the accreted material. Once the maximum thickening and shortening allowed by the strength of the sediment is attained, the accretionary prism further maintains its seaward taper by subsurface underplating or by new thrust faults that cut the accretionary body at a low angle (out of sequence thrusts). Underplating beneath the older part of the accretionary mass tends to isolate it from shear stresses generated along the underlying plate boundary. Rapid tectonic shortening and thickening of the older frontal mass thus cease, and the position of the active buttress shifts seaward.

In this paper we locate the active buttress as the point landward of which horizontal shortening of frontally accreted material greatly slows and volumetric growth of the prism is effected principally by underplating (Figure 3a) (see, for example, Watkins et al. [1982], Moore et al. [1982], Platt et al. [1985], Brown et al. [1990], Ladd et al. [1990], and Snavely and Wells [1991]). Sediment that subducts beneath the margin's core buttress may yet be accreted to the base of the upper plate by underplating processes. But such subcrustally underplated material, although part of the general subduction accretion process, has bypassed the geographic or structural position of the accretionary prism and is not considered part of this body (Figures $3 a$ and $3 c$ ). Unfortunately, even adjacent to the active buttress, seismic resolution of subsurface structures is typically insufficient or too equivocal to identify underplated sediment either within the accretionary prism or beneath the margin's rock framework.

Our approach to quantifying subducted and accreted sediment is to principally consider the frontally accreted material, thus moving the computational point of where sediment subduction begins from the core buttress to as close as possible to the active buttress (point $Y$ to $X$, Figure $3 a$ ). This approach minimizes dealing with the deeply 
buried older part of the accretionary prism where the sediment age, physical dimensions, and internal structures are poorly known. It allows us to isolate relatively good estimates of the contemporary and long-term rates of frontal sediment accretion and sediment subduction from less constrained calculations based on an analysis of the entire accretionary body. We do, however, attempt through mass balance calculations to estimate the amount of subducted sediment that bypasses the accretionary prism and subcrustally underthrusts the margin's rock framework.

The diagrams of Figure 3 and the seismic reflection records of Figure 4 demonstrate that sediment moving landward beneath the frontal part of the accretionary wedge typically does so below a nearly horizontal surface of detachment, which is commonly called the decollement. The decollement is the principal boundary separating the upper and lower converging plates. Sediment above the decollement detaches to form the frontal accretionary pile. Below the decollement, sediment underthrusts the actively growing accretionary pile, and landward of its active buttress, subdecollement sediment is subducted (The term decollement refers to a fault along a bedding plane. In describing subduction zones, decollement is commonly extended to include sections of the plate boundary where the master thrust crosses bedding planes. In accord with the common usage of this term, we use decollement as a synonym for plate boundary. Some authors infer that the plate boundary becomes a zone of distributed faulting and that the decollement is the lowest fault in such a zone [Cloos and Shreve, 1988b, p. 509] (Figure 3a).

If the decollement moves downward within a packet of subducted sediment, the material of the lower plate can be transferred to the upper one, thus effecting underplating
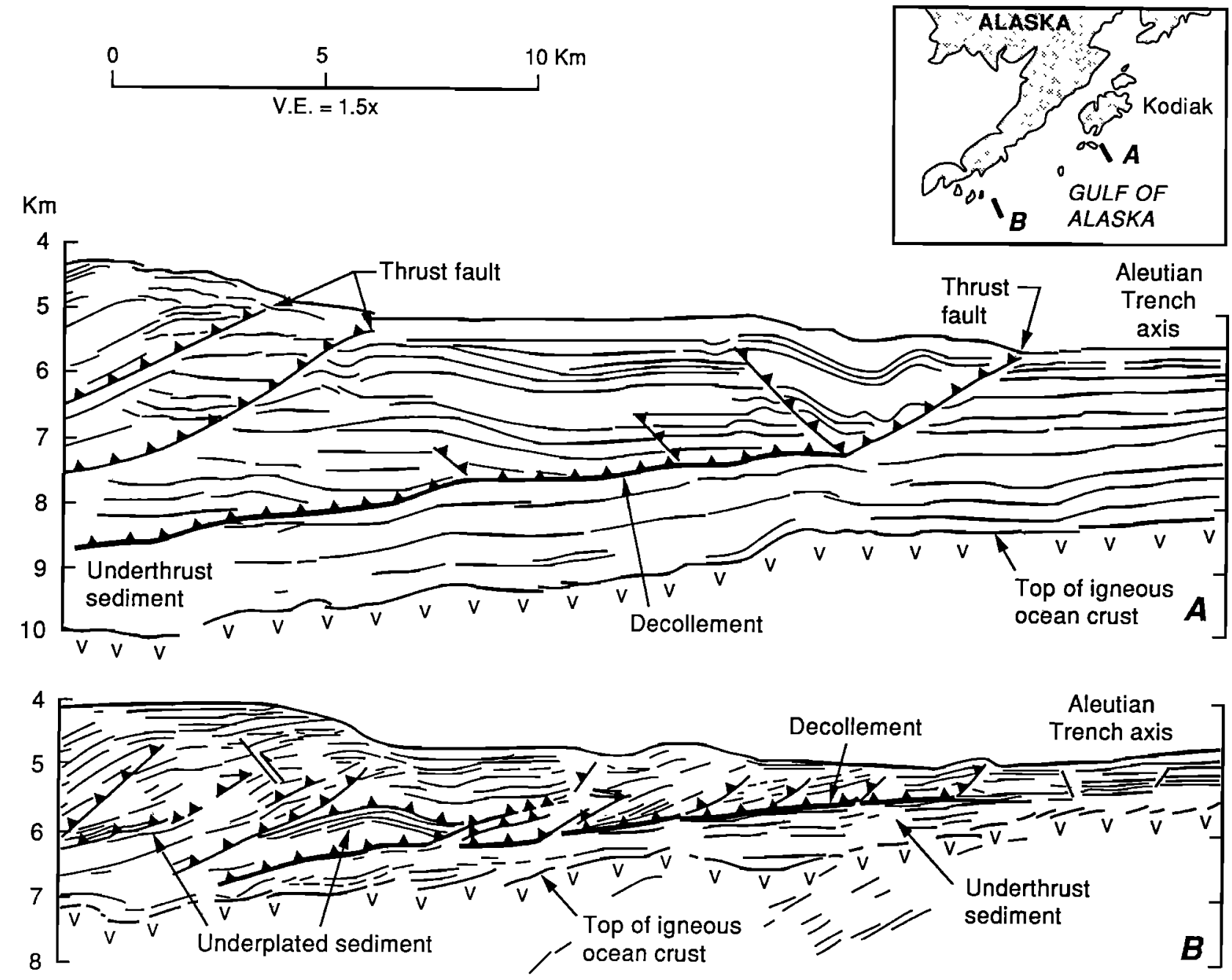

Figure 4. Line drawings, in depth, of two seismic reflection sections that show the decollement separating the upper and lower plates. The upper section $(a)$ crosses the eastern Aleutian Trench off Kodiak Island, Alaska, and the bottom profile $(b)$ traverses the lower trench slope off the Shumagin Islands, Alaska Peninsula. 
and volumetric growth of the prism (Figure 3a). Conceptually, the decollement can also move upward and transfer accreted material to the lower plate, thus promoting subduction erosion [Charlton, 1988; Cloos and Shreve, $1988 a, b]$.

\section{Observations}

Sediment subduction is presumed to have occurred where the volume of sediment accreted frontally to a buttress is less than that which could have been so accreted (Figure $3 b$ ). That is, if the measured size of the frontally accreted mass is less than its potential size (had all incoming sediment been frontally accreted during a prescribed time) then sediment underthrusting and subduction has taken place. In these calculations, subdecollement sediment passing beneath the actively growing frontal mass is included in the subducted fraction. The potential size of a frontal accretionary body is the approximate product of (1) the time during which the sediment accreted, (2) the time-average rate of orthogonal plate convergence, and (3) the time-average thickness of sediment entering the subduction zone (Figure $3 b$ ). Where exceptionally wide accretionary masses have formed, the seaward growth rate should be added to the convergence rate [Davis and Hyndman, 1989].
With clear seismic images and knowledge of the velocity of sound in accreted rock units the size of a frontal accretionary mass can be estimated (see, for example, Bally [1983], von Huene [1986], Westbrook et al. [1988] and Ryan and Scholl [1989]). The age of the measured accretionary mass can be best estimated by subsurface samples recovered at drilling sites of the Deep-Sea Drilling Project (DSDP) or the Ocean Drilling Program (ODP). For Neogene time (approximately the past $22 \mathrm{~m}$.y. or since the earliest Miocene) the orthogonal conversion rate can be extracted from many sources [e.g., Minster and Jordan, 1978; Engebretson et al., 1985; Jarrad, 1986a; Gordon and Jurdy, 1986].

Information adequate to underwrite mass balance calculations can be best compiled at seven accretionary prisms. Six of these are for small-to-medium-width prisms $(5-40 \mathrm{~km}$ from the trench axis to the core buttress, Figure $3 c$ that border the Pacific Basin; the seventh is representative of the much larger accretionary prism (150-250 $\mathrm{km}$ ) flanking the Barbados region of the Atlantic's Lesser Antilles margin (Figures $3 c$ and 5). The Pacific prisms are listed on Table 1, which compares the measured volumetric mass of their frontally accreted body to the potential volumes. A structurally defined core buttress, which serves as the inner boundary, exists for each of the Pacific margins. Unfortunately, it is difficult to clearly

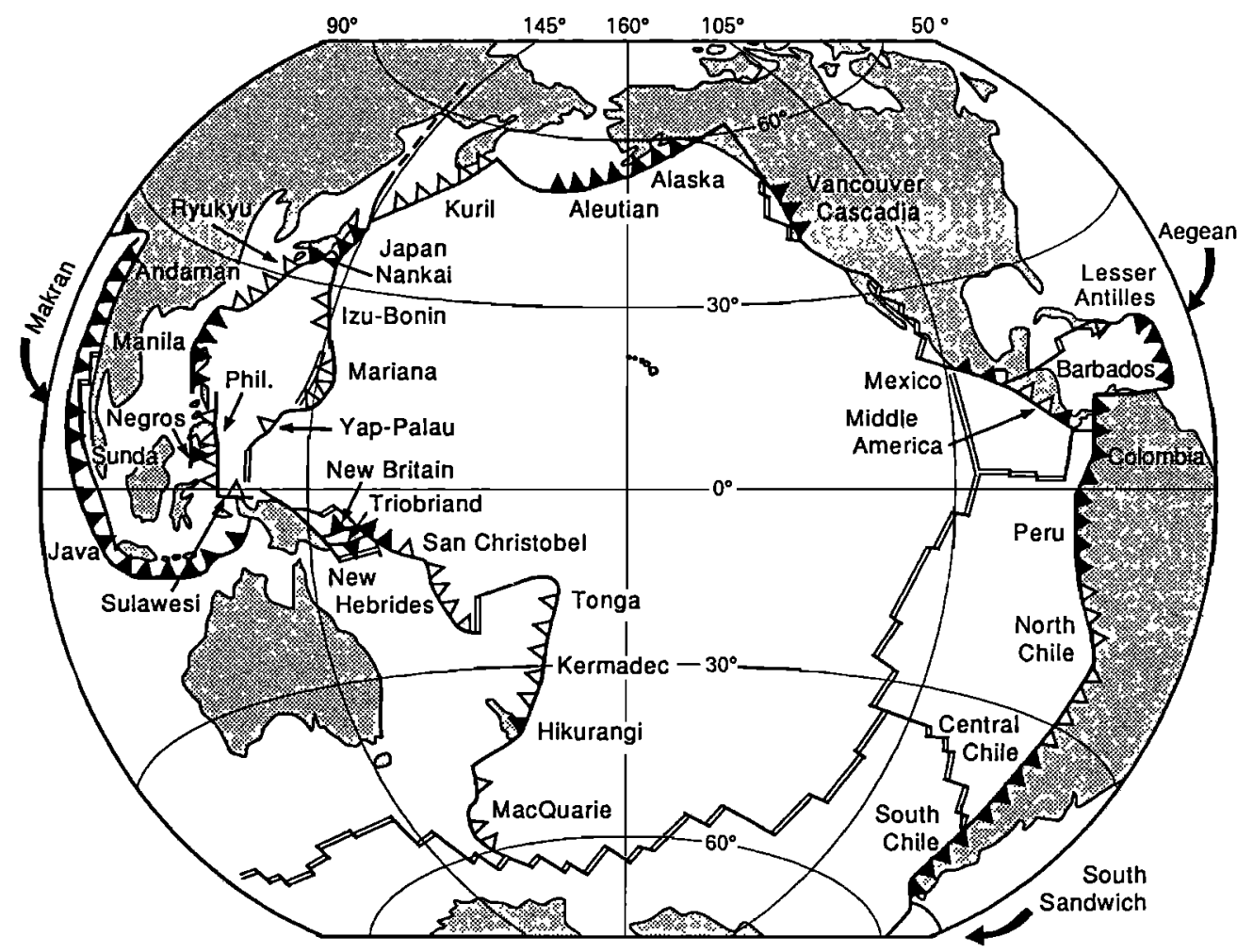

Figure 5. Trenches (barbed lines) and convergent margins of the Pacific, Caribbean, and eastern Indian Ocean regions. Not shown, but indicated, are the short trench systems of the Makran region of the Gulf of Oman, northwestern Indian Ocean, the South Sandwich Trench connecting South America and Antarctica, and the Aegean region of the Mediterranean. Filled barbs are type 1 or accreting trenches, open barbs are type 2 trenches at which effectively no accretionary prism forms (see Table 2). 
distinguish frontally accreted from underplated material on seismic reflection records. As a consequence, the size of the frontally accreted bodies listed on Table 1, especially for the Mexico, Alaska, and Aleutian margins, includes some underplated sediment (perhaps as much as $15-20 \%$ ). This circumstance increases the calculated efficiency of frontal accretion over that of sediment subduction. Thus for the Pacific-margin prism on Table 1 the frontal accretion percentages shown are probably maximum values.
Although the contemporary thickness of incoming trench floor deposits is accurately measured by seismic reflection techniques, estimates of past thicknesses become increasingly uncertain with time. This problem is especially troublesome for the past several million years owing to higher glacial age rates of delivery of terrigenous sediment to the ocean floors. Our calculations in Table 1 account for the increase in sedimentation during glaciation that is most applicable to high-latitude trenches and trenches with wedge-shaped bodies of axial turbidite

TABLE 1. Effective Frontal Sediment Accretion at Pacific Margins Bordered by Small- to Medium-Sized (5-40 km) Accretionary Piles

\begin{tabular}{|c|c|c|c|c|c|c|c|c|c|c|}
\hline Margin & $\begin{array}{c}\text { Measured } \\
\text { Volume of } \\
\text { Accreted } \\
\text { Sediment, } \\
\mathrm{km}^{3} / \mathrm{km} \\
\text { ofTrench }\end{array}$ & $\begin{array}{l}\text { Min. Age, } \\
\text { m.y. }\end{array}$ & $\begin{array}{l}\text { Average } \\
\text { Thickness } \\
\text { of Trench } \\
\text { Sediment, km } \\
0-2.5 \mathrm{Ma} \\
>2.5 \mathrm{Ma}\end{array}$ & $\begin{array}{l}\text { Conver- } \\
\text { gence } \\
\text { Rate, } \\
\text { km/m.y. }\end{array}$ & $\begin{array}{c}\text { Average } \\
\text { Porosity } \\
\text { Trench } \\
\text { Sediment }\end{array}$ & $\begin{array}{l}\text { Solid- } \\
\text { Fraction } \\
\text { Trench } \\
\text { Sediment } \\
\text { Thickness, km } \\
0-2.5 \mathrm{Ma} \\
>2.5 \mathrm{Ma}\end{array}$ & $\begin{array}{l}\text { Average } \\
\text { Porosity } \\
\text { Accreted } \\
\text { Sediment }\end{array}$ & $\begin{array}{l}\text { Solid- } \\
\text { Fraction } \\
\text { Accreted } \\
\text { Sediment, } \\
\mathrm{km}^{3} / \mathrm{km} \\
\text { of Trench }\end{array}$ & $\begin{array}{c}\text { Potential } \\
\text { Solid } \\
\text { Fraction } \\
\text { Volume, } \\
\text { Accreted } \\
\text { Sediment, } \\
\mathrm{km}^{3} / \mathrm{km} \\
\text { of Trench }\end{array}$ & $\begin{array}{l}\text { Percent } \\
\text { Sediment } \\
\text { Accreted }\end{array}$ \\
\hline $\begin{array}{l}\text { Northern Japan }{ }^{a} \\
\text { JNOC-2 }\end{array}$ & 63 & 10.5 & $\begin{array}{l}0.8 \\
0.4\end{array}$ & 100 & $\begin{array}{l}46 \\
55\end{array}$ & $\begin{array}{l}0.43 \\
0.18\end{array}$ & 19 & 51 & $\begin{array}{l}107.5 \\
251.5 \\
144\end{array}$ & 20 \\
\hline $\begin{array}{l}\text { Mid America Trench } \\
\text { Mexico }\end{array}$ & 38 & 10 & $\begin{array}{l}0.6 \\
0.3\end{array}$ & 70 & $\begin{array}{l}50 \\
58\end{array}$ & $\begin{array}{l}0.30 \\
0.13\end{array}$ & 23 & 29 & $\begin{array}{l}52.5 \\
68^{120.5}\end{array}$ & 24 \\
\hline Peru $9^{\circ} \mathbf{S}^{c}$ & 38 & 6.5 & $\begin{array}{r}0.7 \\
0.35\end{array}$ & 100 & $\begin{array}{r}48 \\
56.5\end{array}$ & $\begin{array}{l}0.36 \\
0.15\end{array}$ & 33 & 25 & ${ }_{60}^{90} 150$ & 17 \\
\hline Peru $11^{\circ} \mathrm{S}^{d}$ & 14 & 3 & $\begin{array}{r}0.3 \\
0.15\end{array}$ & 100 & $\begin{array}{l}58 \\
62\end{array}$ & $\begin{array}{l}0.13 \\
0.06\end{array}$ & 25 & 10.5 & $\begin{array}{l}32.5 \\
\quad 35.5 \\
3\end{array}$ & 30 \\
\hline Eastern Alaska Margin & 75 & 5 & $\begin{array}{r}2.5 \\
1.25\end{array}$ & 64 & $\begin{array}{l}31 \\
40\end{array}$ & $\begin{array}{l}1.73 \\
0.75\end{array}$ & 22 & 58.5 & $\begin{array}{c}277 \\
120^{397}\end{array}$ & 15 \\
\hline $\begin{array}{l}\text { C. Aleutian Marginf } \\
\text { L9-6 }\end{array}$ & 116 & 6 & $\begin{array}{l}2.0 \\
1.0\end{array}$ & 75 & $\begin{array}{l}33 \\
42\end{array}$ & $\begin{array}{l}1.34 \\
0.58\end{array}$ & 20 & 93.5 & $\begin{array}{l}251 \\
\quad 403 \\
152\end{array}$ & 23 \\
\hline $\begin{array}{l}\text { C. Aleutian Margin } \\
\text { L9-6 }\end{array}$ & 116 & 6 & $\begin{array}{l}2.0 \\
1.0\end{array}$ & 75 & $\begin{array}{l}41 \\
46\end{array}$ & $\begin{array}{l}1.18 \\
0.54\end{array}$ & 24 & 88 & $\frac{221}{142^{363}}$ & 24 \\
\hline
\end{tabular}

\footnotetext{
${ }^{2}$ Accreted volume, age, trench floor thickness, and convergence rate derived from Nasu et al. [1980] and R. von Huene and J. Miller (unpublished data, 1991).

${ }^{5}$ Accreted volume, age, trench floor thickness, and convergence rate derived from Collins and Watkins [1986], Moore et al. [1982], and Moore and Shipley [1988].

${ }^{c}$ Accreted volume, age, trench floor thickness, and convergence rate derived from Kulm et al. [1986] and Suess et al. [1988].

Accreted volume, age, trench floor thickness, and convergence rate derived from von Huene and Miller [1988] and Suess et al. [1988].

'Accreted volume, age, trench floor thickness, and convergence rate derived from von Huene et al. [1986, 1989].

${ }^{f}$ Accreted volume, age, trench floor thickness, and convergence rate derived from McCarthy and Scholl [1985], Scholl et al. [1987], and Ryan and Scholl [1989] and density, velocity, and porosity relations described by Hamillon [1976, 1978].

${ }^{g}$ Average porosity determined using multichannel stacking veocities [McCarthy and Scholl, 1985; Ryan and Scholl, 1989] and density conversion curves of Hamilton [1976, 1978].

The average porosity of trench sediment determined from Figure 6, except for the bottom row of porosity values for the central Aleutian Trench, which are based on converting interval velocity information to in situ porosity (see footnote $g$ ).

The average porosity of the accreted material determined from Figure 6, except for the bottom row of porosity values for the central

Aleutian Trench, which are based on converting interval velocity information to in situ porosity (see footnote $g$ ).

${ }^{j}$ Potential solid-fraction volume $=$ (age) (solid-fraction trench thickness) (convergence rate).

${ }^{k}$ Percent accreted $=($ solid-fraction volume accreted/potential volume $) \times 100$.
} 
deposits. These wedges are only a few hundred thousand years old, and they can be maintained along the trench axis only by exceptionally high rates of terrigenous sedimentation [von Huene and Kulm, 1973; Helwig and Hall, 1974; Scholl, 1974]. Major rate increases can thus rapidly thicken the trench floor deposits entering the subduction zone.

Recent high-resolution studies of stable isotope stratigraphy indicate that ocean water cooled noticeably between 3.1 and $3.5 \mathrm{Ma}$ and that temperatures reached the levels commonly observed during the Pleistocene about 2.5 Ma [Sarnthein and Thiedemann, 1989]. We therefore applied a sediment thickness correction at $2.5 \mathrm{Ma}$. The magnitude of the correction was guided by changes in the global rate of sedimentation in the ocean basins seaward of trenches. The data compiled by Southam and Hay [1981], Sloan [1985], and Hay et al. [1988] show a rough doubling of the rate of terrigenous sedimentation beginning about 3 Ma. Along many trenches, rate doubling could double axial thickness within less than $0.5 \mathrm{~m}$.y. Accordingly, we assumed that the present thickness of the terrigenous or turbidite wedge unit of Pacific trenches may be as much as twice that typical of previous nonglacial times. We explain below that reducing the preglacial trench thickness to one half that of the contemporary section may be a harsh correction. But, for the purpose of not overestimating the volume of sediment subducted at the margins listed on Table 1, we have elected to apply the $50 \%$ correction to the thickness of both the trench wedge and the underlying ocean basin section entering these subduction zones prior to $2.5 \mathrm{Ma}$.

Because accretionary processes at the front of convergent margins vertically stacks and horizontally shortens offscraped trench floor sequences, intergranular or pore fluids are squeezed out of the growing accretionary mass, thus decreasing its volume. To compensate for this fluid loss, mass balance volumes are porosity corrected; that is, they are converted to the solid fraction (zero porosity) volume of the trench axis and accreted sections. Porosity corrections are based on data compiled on Figure 6. For specific areas, down-section porosity values can also be extracted from subsurface velocity data (see Table 1, central Aleutians).

In Table 1 the volume of sediment accreted frontally at six margins (representing $\sim 5,000 \mathrm{~km}$ of convergent margin sectors) is compared with that potentially piled there had all the incoming trench floor sequence been so accreted. The estimates in Table 1 indicate that for prisms 5 to 40 $\mathrm{km}$ wide the frontal mass commonly represents less than $20 \%$ of the sediment that entered the subduction zone during late Cenozoic time. By implication the bulk of the sediment entering the remaining $-11,000 \mathrm{~km}$ of similar subduction zones elsewhere, but at which mass balance calculations cannot be constrained, is also subducted rather than frontally stored. We think the fractional portions of $20 \%$ accreted and $80 \%$ subducted presently best represent the partitioning factor for the entire $\sim 16,000-\mathrm{km}$ global length of convergent margins bordered by small-to- medium-sized accretionary prisms (Figure 3c). These subduction zones are listed as type 1 margins on Table 2 , which is a compilation of information used to calculate the contemporary volume of sediment entering and being subducted at all trenches.

Differing with the implications of the data on Table 1, Davis and Hyndman [1989] report that the outer or frontal part of the Vancouver prism of the northern Cascadia margin (southern British Columbia and northern Washington, Figure 5) is balanced to the volume of sediment expected to have entered this subduction zone during the past $1.8 \mathrm{~m} . y$. , and, less securely, during the past 40 m.y. The large Vancouver accretionary prism has accumulated seaward of a core buttress of Eocene and older igneous and sedimentary rocks. At the deformation front of the Vancouver prism, seismic reflection data show that the decollement lies at the surface of the igneous oceanic crust and thus at the base rather than within the incoming sedimentary section. Evidently, presently, in the Vancouver accretionary process the entire thickness of incoming sediment is being frontally accreted (see also Calvert and Clowes [1990] and Snavely [1987]).

In the calculations of Table 2 we assume that along the southern sector of the Cascadia margin the efficiency of frontal accretion is more typical of that of the margins listed on Table 1. Off Oregon, a prism-front decollement is established at least $1.5 \mathrm{~km}$ above the base of the incoming sedimentary section of the Cascadia Basin [Snavely et al., 1986, MacKay et al., 1989]. We further note that at the front of the southern Chile and eastern Alaska prisms thrust faults also reach downward to the igneous basement, but farther landward thrusts bottom along a decollement that separates accreting and underthrusting sediment. The possibility that frontal accretion is exceptionally efficient where a decollement does not form within the body of sediment at the front of the prism may therefore not be a widely applicable interpretation.

But, as Davis and Hyndman [1989] infer, some of the truly massive accretionary bodies may achieve their exceptional size because factors that favor efficient offscraping operate at these margins, for example, slow convergence speeds and thick $(2-6+\mathrm{km})$ incoming sections of relatively coarse grained (silty and sandy) terrigenous beds. At the very large Barbados prism of the Lesser Antilles and that of the Makran area of southern Pakistan (Figure 5), prominent within-section decollements occur well above the igneous basement [Platt et al., 1985, Westbrook et al., 1988; Minshull and White, 1989; Brown et al., 1990]. The within-section position of the decollements imply that the tectonic fate of the thick incoming sedimentary section to these large accretionary prisms includes subduction, underplating, and, most likely, bypassing (Figure 3c).

Evidence of the general or global efficiency of sediment subduction is provided by the observation that lengthy segments of convergent margins are effectively nonaccretionary. These trenches are listed as type 2 margins on 

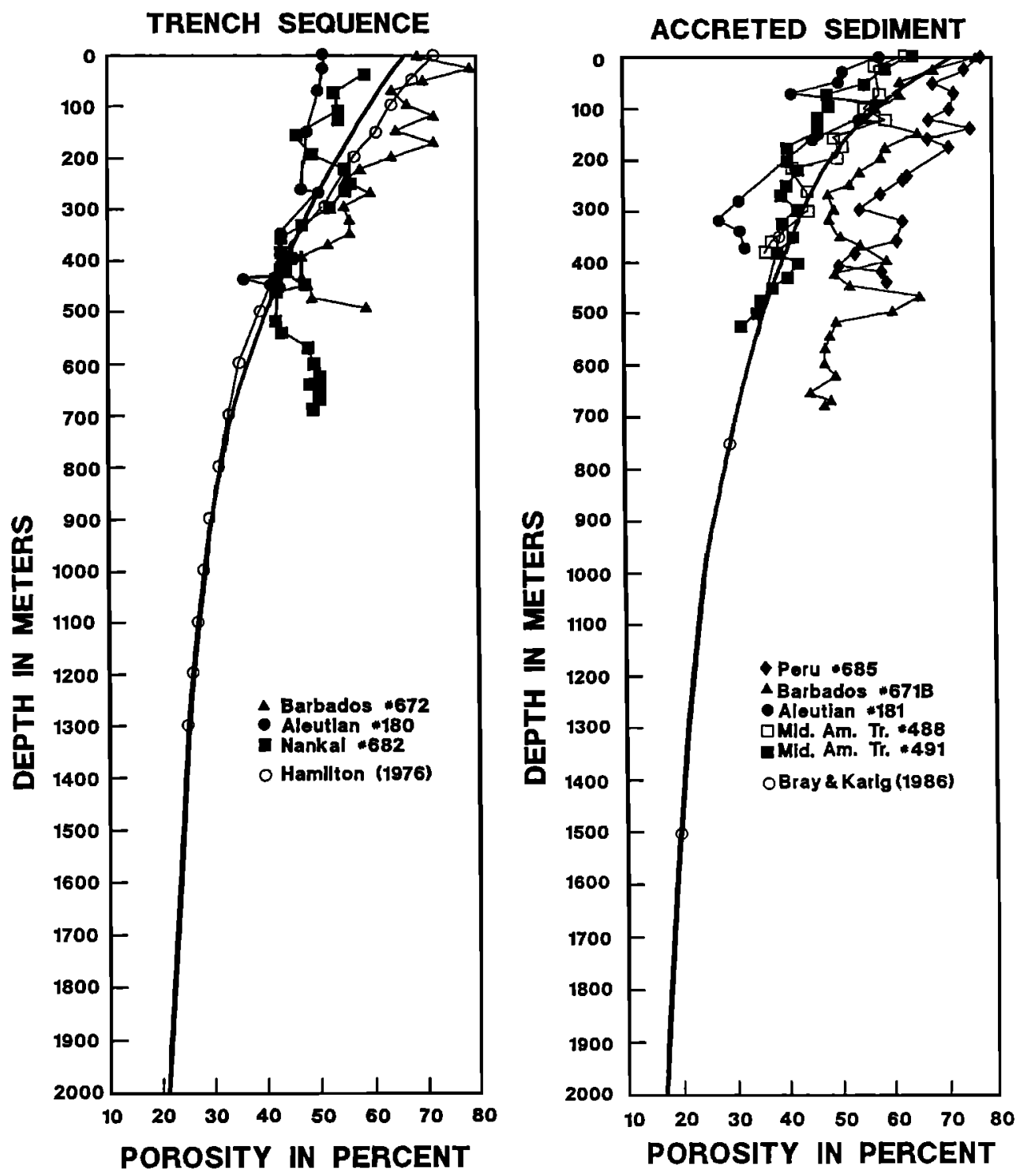

Figure 6. Depth versus porosity curves of trench floor sedimentary deposits and those of the accretionary prism. Upper data points compiled from DSDP and ODP cores. Deeper porosities for accreted material based on correlation between seismic velocity and porosity of Bray and Karig [1985]; deeper porosity information for the trench floor section taken from Hamilton [1976].

Table 2 (Figure $3 c$ ). An example of a nonaccretionary trench borders the Middle America Trench off Guatemala, where a deeply towed seismic system detected an accretionary mass only a few hundred meters wide [Moore et al., 1982]. Immediately shoreward, the landward trench slope is underlain by a core buttress of igneous ocean crust of Cretaceous age that was accreted in Eocene time [Aubouin and von Huene, 1985]. Although underthrusting has occurred beneath this rock framework since at least Eocene time (past 37 m.y.), the net amount of frontal accretion is very small.

Similarly, along virtually the length of the western Pacific, from Kamchatka southward via the Kuril, Japan (excepting the northem Japan Trench), Bonin, Mariana, Yap, Palau, and Tonga trenches to near New Zealand, accretionary prisms of a size to be readily detected (few kilometers wide) are uncommon to rare (Figure 5; Table 2; see, for example, from north to south, Seliverstov [1987] (Kamchatka Trench), Gnibidenko et al. [1980] (Kuril Trench), Fujioka [1985] and von Huene and Culotta [1989] (Japan Trench), Honza and Tamaki [1985] (Bonin Trench), Hussong and Uyeda [1982] and Hussong and Fryer [1985] (Mariana Trench), Kobayashi et al. [1985] (southem Mariana-Yap-Palau Trenches), and Scholl and Vallier [1985], Lonsdale [1986], and Pelletier and Dupont [1990] (Tonga Trench). Western Pacific trenches lack accretionary masses because the supply of terrigenous sediment reaching the trench floor is insufficient to nourish their growth. Nonaccreting margins are thus typically bordered by sediment-starved trenches. As a consequence, 
TABLE 2. Solid Mass of Sediment Subducted at Convergent Ocean Margins

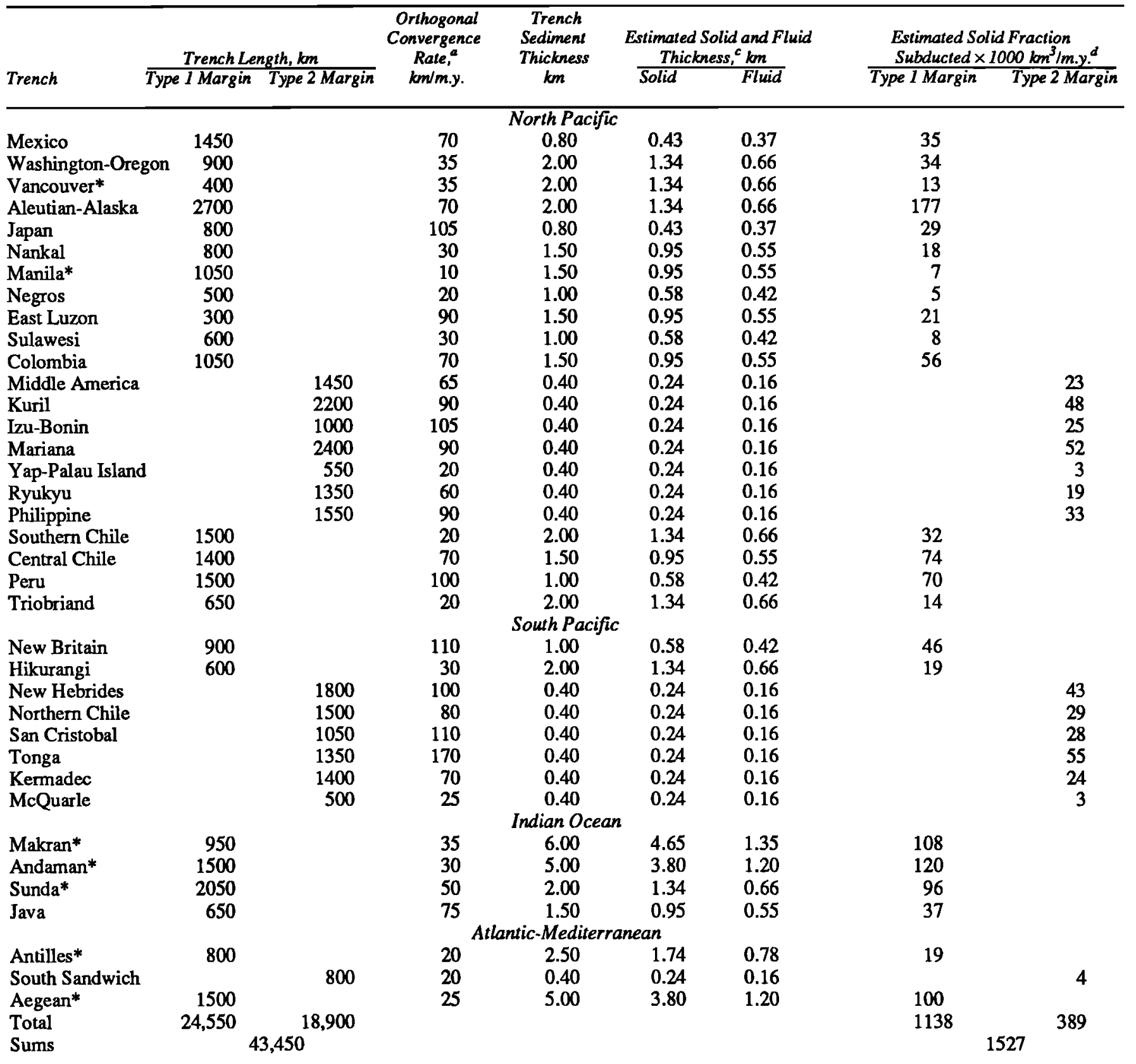

${ }^{a}$ Orthogonal convergence from Minster and Jordan [1978], Jarrard [1986a], J. T. Bruns, M. Fisher, S. Lewis, and E. Silver (personal communication, 1990), and numerous publications for specific sectors of convergent margins. Where appropriate, back arc spreading rates were included in convergence rates listed.

${ }^{b}$ Average thickness estimates based on examined seismic reflection records, for example, those published by Bally [1983] and yon Huene [1986] as well as numerous other authors.

The solid- and fluid-fraction thicknesses for type 1 margins are based on the porosity-depth curve of Figure 6. Thickness for type 2 margins are based on the average porosity of the Pacific Ocean basin section [Howell and Murray, 1986].

${ }^{d}$ For type 2 margins, estimates were based on $100 \%$ of solid-fraction thickness of trench. For type 1 with small- to medium-sized prisms, estimates were based on $\mathbf{8 0 \%}$. For type 1 with large accretionary prisms, estimates were based on $70 \%$. The latter are indicated by asterisks. 
despite tens of millions of years of underthrusting by an ocean plate typically covered with a layer of pelagic oceanic sediment 200-600 m thick, the rock framework of most western Pacific margins are not fronted by accretionary masses but remain exposed at the inner trench wall [Bloomer, 1983; Bloomer and Fisher, 1987, 1988]. On Figure 7 the multichannel seismic profiles that traverse the lower slope of the Tonga Trench are exemplary of nonaccreting margins. On the opposite or eastern side of the Pacific, similar nonaccreting, sediment-starved margins are reported from southem Peru to southcentral Chile $\left(20^{\circ}-33^{\circ} \mathrm{S}\right.$; Hussong et al., 1976; Hussong and Wipperman, 1981; Scholl et al., 1970; von Huene et al., 1985; Thornburg and Kulm, 1987].
In our view the widespread occurrence of both nonaccreting margins and accreting margins that retain in frontal accretionary bodies only a fraction of the oceanic sediment provided documents the workings of efficient sediment subduction processes (Tables 1 and 2; Figure 3)). This conclusion is consistent with the paucity of oceanic pelagic sediment exposed in mountain belts of deformed rocks of ancient accretionary complexes [Spencer, 1974; Scholl et al., 1977].

\section{Mechanisms of Sediment Subduction}

The efficiency of sediment subduction is thought to be affected by a number of physical factors, including the volume and texture of sediment supplied and the surface

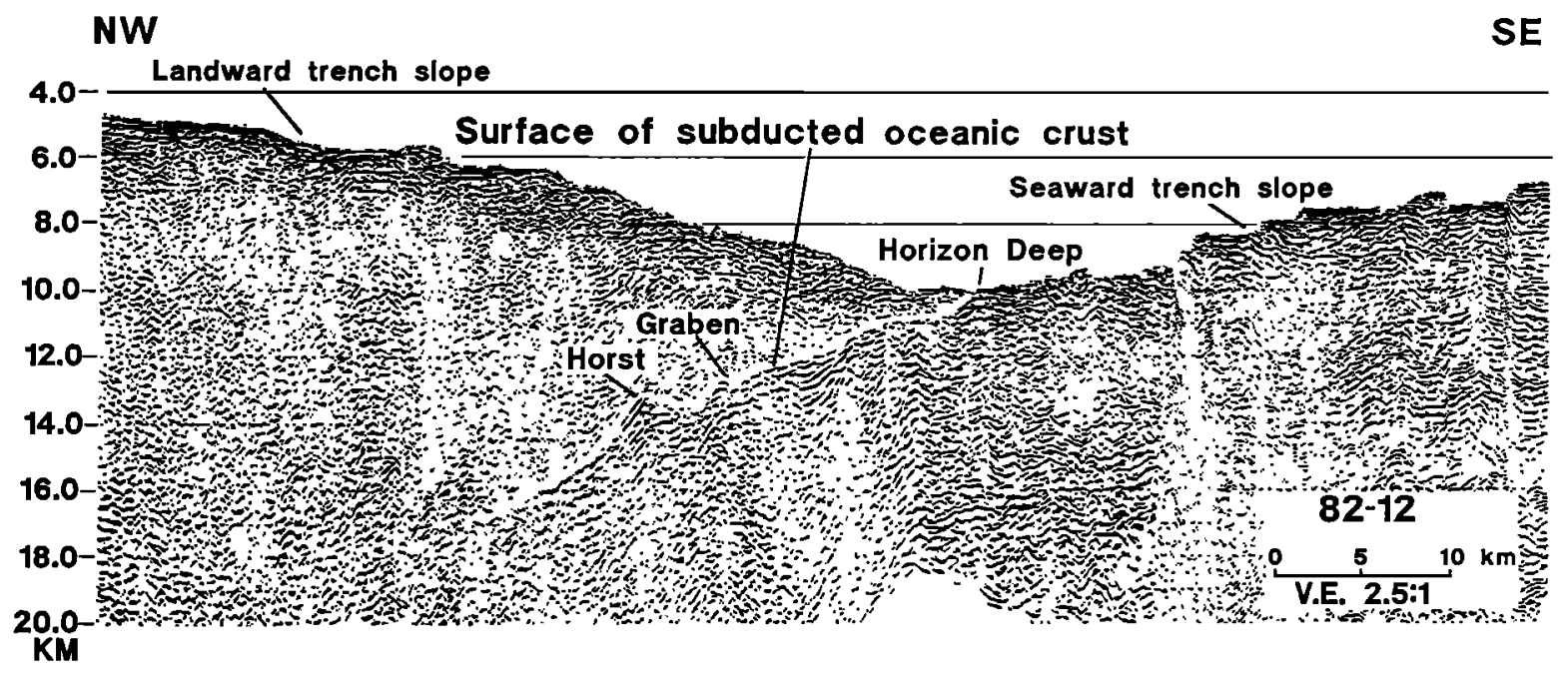

NW

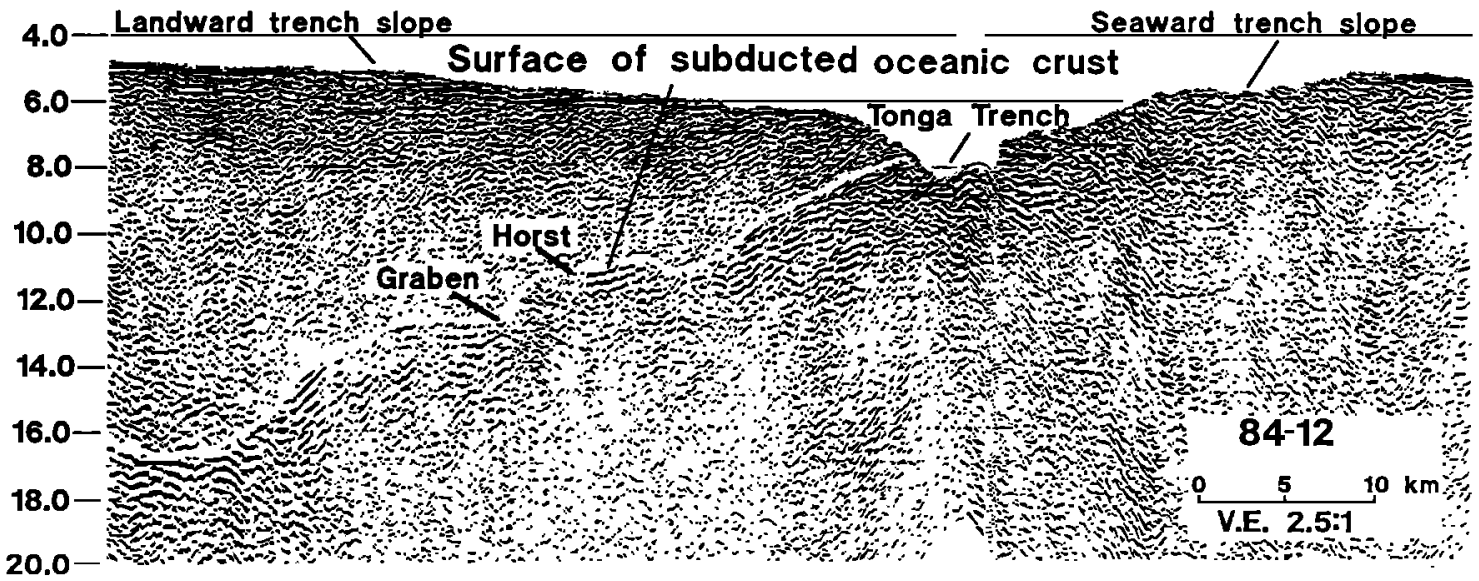

Figure 7. Migrated, depth converted multichannel seismic reflection lines 82-12 and 84-12 that cross the lower landward trench slope of the southern Tonga Trench, a typical example of a type 2 margin at which effectively no accretionary prism forms. Line locations are shown on Figure 17. The underthrusting surface of the oceanic plate (highlighted), which can be traced landward of the trench floor for several tens of kilometers, reveals the undulating profile of subducted troughs (grabens) and ridges (horsts). As they underthrust the inner trench wall, the cavity of the grabens are presumably mostly filled with subducted arc-related sediment and rock framework material. Along the sector of the Tonga Trench crossed by these seismic lines the rate of subduction erosion has been accelerated by its collision with the massif of the Louisville Ridge (see Figure 17). 
relief, descent angle, and orthogonal convergence rate of the underthrusting ocean plate [Cloos and Shreve, 1988a, b]. Two somewhat different tectonic processes are involved in sediment subduction. The first is associated with the underthrusting of ocean floor relief that is not buried by thick depositional sequences; for example, the Tonga Trench (see Figure 7). The second concerns the partial subduction of sedimentary sections that are sufficiently thick to overwhelm ocean floor relief; for example, the eastern Aleutian Trench (Figure 4a).

The seaward slopes of many ocean trenches typically exhibit a surface relief of fault-bordered ridges and valleys, horsts and grabens (Figure 1, also see Figure 15). Horsts and grabens form seaward of trenches in response to bending stresses engendered by the downward flexing of the oceanic plate toward the subduction zone [Jones et al., 1978]. The depth or relief of the grabens is commonly 300-500 m but may reach $1 \mathrm{~km}$ or more [Lonsdale, 1986]. Their width is generally a few kilometers to as much as 10 $\mathrm{km}$.

Seaward of sediment-starved trenches, the faulted oceanic crust is overlain by a mostly prefault-age blanket of ocean basin pelagic sediment typically $200-600 \mathrm{~m}$ thick. Terrigenous debris supplied by mass wasting or collapse of the landward trench slope must fill the void of the grabens as they pass beneath it. Thus at the base of the slope, relatively thick debris piles are stacked atop the blanket of pelagic sediment. The general process of subducting relatively thin sections of ocean floor sediment in grabens has been described by Schweller and Kulm [1978, Schweller et al. [1981], and Hilde [1983]. Key to the subduction process is the establishment of a decollement or master slip surface between the two plates across the tops of the horsts and debris-infilled depressions of the grabens. Subducted basement relief revealing the lows of grabens and the highs of flanking horst blocks are commonly imaged on seismic reflection records, for example, those of Figure 7 and 13.

Where sufficient sediment has accumulated to deeply cover basement relief, the tops of horst blocks are not involved in determining the position of the decollement. Along the Japan and eastern Aleutian margins, seismically imaged basement relief is $500 \mathrm{~m}$ and more beneath the decollement [von Huene and Culotta, 1989]. The subsurface position of the decollement is typically determined at a stratigraphic boundary within the trench floor sedimentary sequence. Commonly, the decollement is established at the contact between the lower unit of ocean basin sediment and the overlying wedge-shaped unit of the axial trench fill [Aoki et al., 1982; Hayes and Lewis, 1984; Moore and Shipley, 1988]. However, where the wedge is thick, the decollement may be established within the axial turbidite fill [McCarthy and Scholl, 1985; Moore et al., 1986]. Or, where the lower ocean basin section is unusually thick, the decollement may form within it [Moore and Biju-Duval, 1983; Westbrook et al., 1988; Brown et al., 1990; Mascle and Moore, 1990].
Although the upper or frontally accreting unit was acoustically imaged in the late 1960 s and early 1970 s (see, for example, Chase and Bunce [1969] and Hilde et al. [1969]), the existence of the partitioning decollement and the lower underthrusting and effectively undeformed sedimentary sequence was first convincingly demonstrated in the early 1980s by Aoki et al. [1982]. Clearly, imaged decollements have since been recorded from many other convergent margins (Figure 4), for example southern Alaska [von Huene et al., 1983; von Huene, 1986], northern Oregon [Snavely et al., 1986; Snavely and Wells, 1991], the Barbados region of the Lesser Antilles [Westbrook and Smith, 1983; Moore et al., 1988], the Aleutian arc [McCarthy and Scholl, 1985], the Middle American Trench segments bordering Costa Rica [Shipley and Moore, 1986] and Mexico [Moore and Shipley, 1988].

It was emphasized earlier that the physical process of underthrusting and potentially subducting a mechanically weak section of sediment requires an environment along the decollement of low stress and thus greatly reduced sliding friction [von Huene and Lee, 1982; Carson et al., 1982; Westbrook and Smith, 1983; von Huene, 1984; Davis and von Huene, 1987; Minshull and White, 1989]. Most authors ascribe stress reduction to elevated (greater than hydrostatic) pore fluid pressures, which Hubbert and Rubey [1959] had decades before proposed was the essential condition explaining the mechanics of thrust faulting. Elevated pore pressures bear much of the weight, or lithostatic load, imposed by the upper plate, which is thereby effectively floated above a low-shear-strength decollement. In effect, lubrication theory can be applied to model the sediment subduction process [Shreve and Cloos, 1986; Cloos and Shreve, 1988 a, b].

Field observations and modeling studies demonstrate that lithostatic loading in the subduction zone causes subsurface fluid pressures to elevate. Numerical studies indicate that where trench axis sedimentation is rapid, overpressured conditions can exist even before the trench section is offscraped and stacked in a frontal accretionary pile [Shi and Wang, 1985, 1986, 1988]. Offscraped deposits are commonly muddy, thus their permeability is low. The rate of deposition along rapidly sedimented trenches is at least an order of magnitude greater than over the adjacent seafloor. Excess fluid pressures arise within these rapidly accumulated sections because depositional loading acts to compact underlying strata and expel their pore fluids at the seafloor. But the low permeability of the compacting section and the steadily lengthening migration path to reach the trench floor hinders fluid expulsion. A large part of the lithostatic load imposed by the thickening trench section is thus transferred to the poorly vented pore fluids. Owing to the rapid loading, the decollement commonly forms near the change in sediment permeability at the surface separating the upper axial wedge from the lower ocean basin section of fine-grained pelagic and hemipelagic beds [Hayes and Lewis, 1985; Moore and Shipley, 1988]. 
Pressures increase landward of the trench axis because of the increasing lithostatic load imposed by the thickening accretionary pile. The tectonic stack of offscraped and underplated trench floor deposits further complicates fluid escape paths. Modeling suggests that more than $90 \%$ of the burden of the accreted wedge can be supported by heightened pore fluid pressures in the subdecollement or underthrusting section [Westbrook and Smith, 1983; Davis et al., 1983; Davis and von Huene, 1987; Borja and Dreiss, 1989]. Seismic images reveal little deformation in subdecollement sediment, thus documenting that weak interplate coupling persists between the underthrusting section and the frontally accreted and underplated masses, as well as some of the margin's rock framework (see, for example, Aoki et al. [1982], Moore and Biju-Duval [1982], von Huene [1986], Brown et al. [1990], Moore et al. [1990], and Shipley et al. [1990]). This observation is consistent with the fact that few major earthquakes occur along the plate boundary underlying the lower slopes of convergent margins [Yoshi, 1979].

Field evidence of elevated subsurface pressures, which are largely summarized by Shouldice [1971]; von Huene and Lee [1982], Carson et al. [1982], Davis and Hyndman [1989], Minshull and White [1989] and the group of papers introduced by Langseth and Moore [1990], has been recognized at many convergent margins. These observations include the low angles of thrust faults and seafloor slopes typical of accretionary wedges, and, within them, the common occurrence of fluid escape structures observed in drill cores. Seismic reflection and seafloor imaging techniques also reveal the abundance of mud volcanoes and mud diapirs, which document the eruption at the seafloor of vertically ascending masses of overpressured, fluid-rich sediment (see, for example, Westbrook and Smith [1983], Breen et al. [1986, 1988], Snavely [1987], Brown and Westbraok [1988], Reed et al. [1990], and Le Pichon et al. [1990]). Direct measurements of fluid pressure near modern accretionary wedges are not numerous, but these measurements confirm modeling studies and the implications of fluid escape structures that overpressured conditions prevail [Hottman et al., 1979; Moore et al., 1983; von Huene, 1985; Minshull and White, 1989].

\section{SUBDUCTION EROSION}

\section{Definitions}

Subduction erosion, a form of tectonic erosion, describes the subduction-caused break up, wearing away, and removal of the rock and sedimentary bodies of an ocean margin. Subduction erosion is not tied to a specific means by which loosened rock masses and debris are transported beneath the margins rock framework. We distinguish the removal processes of subduction erosion from those of sediment subduction by requiring that an eroded rock or sediment mass must have formerly been part of the upper plate. This definition includes material that had been attached to the seaward edge of the upper plate by accretionary processes as well as more landward framework rock and its cover of slope deposits. Von Huene and Lallemand [1990] distinguish between frontal and basal subduction erosion. Processes of frontal erosion loosen and remove rock and sediment masses located at the front or toe of the landward trench slope. Processes of basal erosion subcrustally remove the underside of the upper plate, in particular the margin's rock framework. Both frontal and basal subduction erosion act to reduce the material volume of the margin, thereby causing upper plate thinning and the landward migration of the trench axis. Frontal and basal erosion are the respective converse of frontal accretion and underplating.

\section{Some History and Comments}

Subduction erosion was perhaps first invoked to explain large amounts of missing continental crust along ocean margins. For example, two decades ago Rutland [1971] proposed subduction-linked tectonic erosion as the explanation for the occurrence of a belt of arc igneous rocks of Mesozoic age along the coast of central and northern Chile. Present arc magmatism occurs along the crest of the Andes roughly $220 \mathrm{~km}$ landward of the coastal area and $325 \mathrm{~km}$ inboard of the trench axis. Thus some process of rock removal had placed the Mesozoic arc within $100 \mathrm{~km}$ of the modern Chile Trench.

Reasoning similarly, but independently, Miller [1970a, b] identified subduction-induced tectonic erosion as the process that truncated seaward projecting trends in continental crustal rocks exposed along the coastline of central Chile (Figure $2 b$ ). Along the western side of the Pacific, Murauchi [1971] appealed to tectonic erosion to explain the truncation of well-lithified rocks exhibiting high acoustic transmission velocities, presumably old continental crustal material, off northern Honshu Island, Japan (Figure $2 c$ ). Simplified redrawings of the illustrations Miller and Murauchi used to introduce their concept of subduction erosion are presented, respectively, on Figures $2 b$ and $2 c$. But as Karig [1974] and Karig and Ranken [1983] emphasize, truncation at convergent margins can also be caused by regional strike-slip faulting.

During the $70 \mathrm{~s}$, studies at modern and ancient convergent margins continued to provide evidence of missing material and margin truncation and subsidence (see, for example, Hussong et al. [1976], Scholl et al. [1977], and Ziegler et al. [1981]). But not until the 1980s was the concept of subduction erosion bolstered significantly by the recovery of new offshore evidence, in particular that supplied by deepwater rock dredging, deep-sea drilling, and the acquisition and modern processing of multichannel seismic reflection data. Drill cores and seismic records from the Japan and Peru margins in particular documented deeply buried and subsided erosional surfaces (unconformities) that had been carved near sea level and then buried beneath an advancing shoreline [von Huene et al., 1982, 
1988]. From the coastal region seaward these unconformities tilt downward toward the trench axis and plunge to depths of 4-5 km, which is nearly the depth of the trench floor. Adjacent to the Mariana Trench, although the evidence was less firm for large-scale sinking of the seafloor, DSDP drilling recovered carbonate deposits that suggested at least several kilometers of subsidence [Hussong and Uyeda, 1982]. In all these areas it was argued, subsidence was so substantial that crustal thinning of the upper plate was called for, and most likely by an erosive process linked to the underthrusting action of the lower plate.

Notwithstanding this argument, subsidence of convergent margins of the order of several kilometers and possibly more can involve tectonic processes other than tectonic erosion. The more important of these include (1) depression of the lower oceanic plate and (2) thinning of the upper plate by extension and seaward sliding of the margin's rock framework.

Depression of the lower oceanic plate can be caused by the load imposed by a growing accretionary prism [Karig et al., 1976]. But neither the Japan nor Peru margins, at which subsidence of 4-5 $\mathrm{km}$ was documented [von Huene and Lallemand, 1990], have large accretionary masses of Cenozoic age. The subsided shoreline unconformity also extends many tens of kilometers landward of the accretionary prism where the upper plate is unaffected by accretionary loading. Margin subsidence can also result from an increase in the bulk density of the subducting lower plate, which would cause it to sink deeper into the underlying asthenospheric mantle [Langseth et al., 1981; Hilde and Uyeda, 1982]. The density of oceanic lithosphere is proportional to its age. If increasingly older ocean crust underthrusts a margin, for example as presently happens in the far north Pacific along the Aleutian ridge [Grow and Atwater, 1970; Scholl et al., 1987; Lonsdale, 1988; Atwater, 1989], it can be anticipated that at least the outer margin will progressively subside. But plate reconstruction models show that rapid Neogene subsidence of the Japan and Peru margins was accompanied by little change, or even a decrease, in the absolute age of the underthrusting lithosphere [von Huene and Lallemand, 1990].

Crustal thinning linked to large subsidence occurs where lithospheric slabs are stretched and pulled apart [Wernicke and Burchfiel, 1982], including at continental margins, see, for example, Tankard and Balkwill [1989]. Low-angle detachment faulting, grand-scale sliding, and the unroofing of deep-crustal rock complexes can occur at convergent margins, in particular where massive accretionary piles have formed [Lister et al., 1984; Platt. 1986; Jayko et al., 1987]. Evidence of massive-scale sliding at convergent margins would be regional-scale extension faulting and the translation of rotating blocks of upper plate rock toward the trench. Although extension faults are common on convergent margins, and typical of Japan and Peru, the horizontal and vertical displacements recorded by these fractures are much less than required to explain crustal subsidence of the order of the 4-5 km observed. Also, crustal thinning effected by trenchward extension would increase the width of the margin from trench to arc, whereas observational evidence indicates decrease in width in conjunction with subsidence.

Thinning along the base of the upper plate caused by tectonic erosion of the rock framework can account for any measure of observed subsidence or truncation of ocean margin rocks. Substantially for this reason and the lack of evidence supporting the efficacy of other causes, progressively throughout the 1980 s the process of subduction erosion was accepted by a widening community of Earth scientists [Scholl et al., 1980; Hussong and Uyeda, 1982; Scholl, 1987; Cloos and Shreve, 1988a, b; von Huene and Lallemand, 1990].

\section{Observations}

Unanticipated evidence of subsidence was discovered along the landward slope of the Japan Trench at DSDP site $438 / 439$, located approximately $90 \mathrm{~km}$ landward of the trench in water $1560 \mathrm{~m}$ deep (Figures 8 and 9). At this site an unconformity carved in the early Neogene by subaerial and nearshore erosion was penetrated approximately 2750 m below present sea level (Figure 9) [von Huene et al., 1982]. Drill cores just above the unconformity recovered upper Oligocene conglomerate overlain by sand containing fossils diagnostic of a nearshore or beach environment. The unconformity was cut across a rock framework consisting of a lithified accretionary complex (acoustic velocity $-4.2 \mathrm{~km} / \mathrm{s}$ ) of Late Cretaceous age. Burial of the unconformity by the upper Oligocene beds ended a depositional hiatus of approximately 40 m.y. duration. During the past 22 m.y., younger ocean margin sediment accumulated in increasingly deeper water, thereby documenting the progressive Neogene subsidence of a former subaerial terrane (Figure 9) [von Huene et al., 1982]. Seismic reflection records image the unconformity as a distinctive horizon truncating dipping beds of the underlying Cretaceous accretionary body (Figures $4 a, 9$, and 13). In the reflection data the unconformity can be traced from the lower trench slope, at a depth nearly $7 \mathrm{~km}$ below sea level, to the inner shelf, and these records verify that subsidence affected thousands of square kilometers of the Japan margin (Figures 8 and 9).

Assuming subsidence was caused by subduction erosion, the amount of material eroded from the base of the upper plate to account for the subsidence can be estimated by comparing the margin's present structural dimension with that existing in the early Neogene. Reconstructing the early Neogene margin is explained fully by von Huene and Lallemand [1990], but the procedure basically involves (1) placing the seawardmost point of the unconformity at sea level, (2) dropping a descending slope parallel to the modern one from this point to the early Neogene trench axis, (3) determining the depth of the early Neogene trench axis, and (4) determining the ancient subsurface profile of 


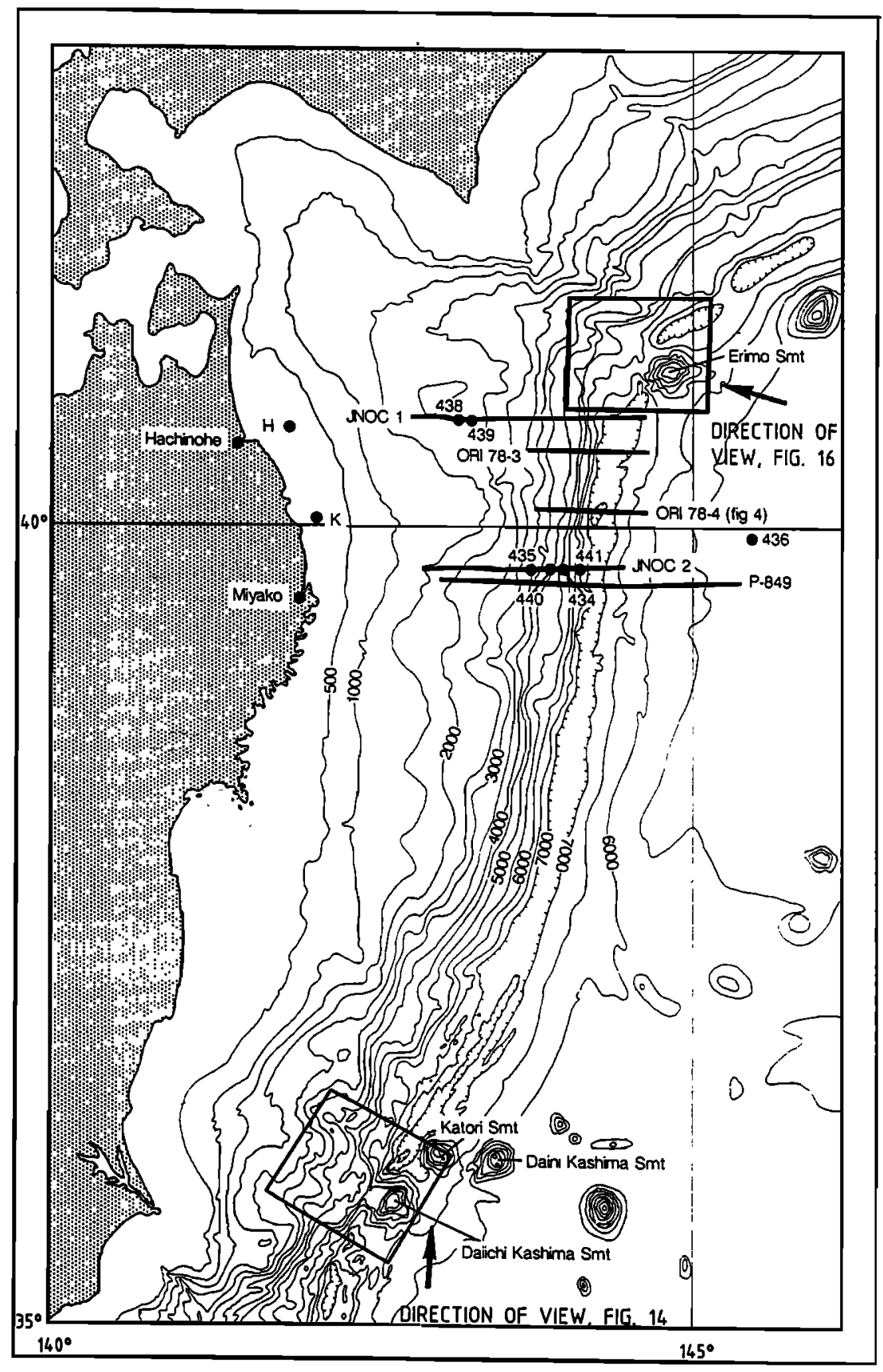

Figure 8. Index map of northem Japan, showing generalized bathymetry and location of multichannel seismic lines in the vicinity of DSDP sites (large dots with numbers) and used to draw Figures 9, 11, and 13. Boxes outlines mesh-net perspective diagrams, and direction of viewing of seamounts illustrated on Figures 14 and 16.

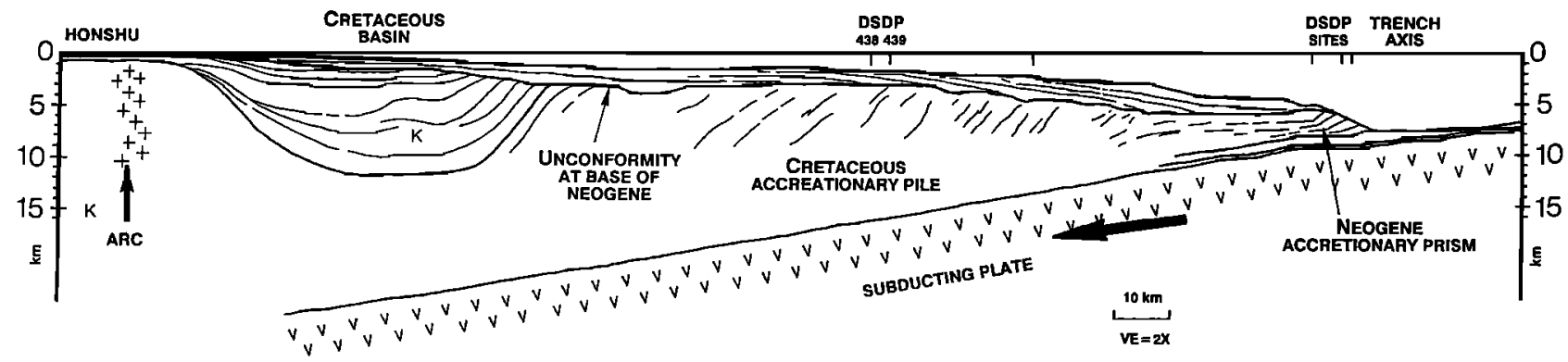

Figure 9. Geologic section across the Japan margin showing general structural relations, including the location of DSDP drill sites, major rock and sedimentary units, the drowned mid-Cenozoic unconformity, and the Neogene accretionary prism. 
the oceanic plate from the paleotrench axis landward beneath the margin (Figure 10). The depth of the early Neogene trench can be fixed by the empirical relation established by Hilde and Uyeda [1982] relating age of subducting crust and trench depth. The plate reconstruction of Sager et al. [1988] indicates that in the early Neogene, 60-m.y.-old crust was at the trench axis, a plate age that corresponds to a paleotrench depth of about $8 \mathrm{~km}$. The profile of the underriding oceanic plate is reconstructed from the paleotrench axis to a location inland where the lower plate reached a depth of about $100 \mathrm{~km}$, the typical depth above which arc volcanism occurs. The $100-\mathrm{km}$ deep tie point, which is located beneath the axis of early Neogene arc volcanism, is essentially coincident with the axis of contemporary arc volcanoes.

In the reconstruction the early Neogene profile of the underthrusting plate must be adjusted downward from the position of the modern one to compensate for the removed lithostatic load of a formerly thicker upper plate (Figure 10). As the mass of the upper plate was progressively lessened by subsurface erosion, the load it imposed on the underthrusting plate steadily lessened, thus causing the plate interface to isostatically rise. Correction for the uplift is estimated by modeling a bending elastic plate subjected to an underlying hydrostatic restoring force [Karig et al., 1976].

By subtracting the volume of the modern Japan margin from the reconstructed early Neogene margin the volume of removed material can be identified (Figure 11) [von Huene and Lallemand, 1990]. Thus during the past $20 \mathrm{~m}$.y. for each linear kilometer of Japan margin, approximately $1110 \mathrm{~km}^{3}$ of upper plate material have been eroded. The volume rate of subduction erosion has averaged approximately $50 \mathrm{~km}^{3} / \mathrm{m} . \mathrm{y}$. per $\mathrm{km}$ of the Japan margin.
Because the rate of orthogonal underthrusting has averaged near $100 \mathrm{~km} / \mathrm{m}$.y., the approximate solid-volume thickness of the layer of eroded material transported landward beneath the upper plate has averaged $0.5 \mathrm{~km}$. This layer is composed of material removed from the base of the upper plate's rock framework and mass-wasting debris that reached the base of the trench slope but that did not accrete there. Subsidence of the margin was attended by the relative landward migration of the trench axis by about $75 \mathrm{~km}$ [von Huene and Lallemand, 1990]. The subcrustal transport of eroded material is in addition to that injected beneath the core buttress by sediment subduction, which presently contributes a roughly equivalent solidvolume mass (Table 2). The calculated solid-volume thickness of subducting material is thus about $1 \mathrm{~km}$, a measure that is in keeping with the 2-km-thick layer of sediment and debris that has been seismically imaged beneath the seawardmost edge of the core buttress [von Huene and Culotta, 1989].

Hussong et al. [1976] were among the first to point out evidence for large-scale subsidence of the central Peru margin, which they ascribed to subduction erosion. Reprocessed seismic reflection data and drilling results along a $600-\mathrm{km}$ stretch of the Peru margin $\left(8^{\circ}\right.$ and $14^{\circ} \mathrm{S}$ latitude) have now documented a subsidence history similar to that of Japan (Figure 12) [von Huene et al., 1988]. Seismic records reveal a regional unconformity extending seaward from the shelf to at least the middle region of the trenchward descending continental slope (Figure 9) [Hussong et al., 1976; Hussong and Wipperman, 1981; von Huene et al., 1985; Ballesteros et al., 1988]. Petroleum exploration drilling and dredging of submarine outcrops have recovered crystalline metamorphic rocks of Paleozoic age from below the unconformity

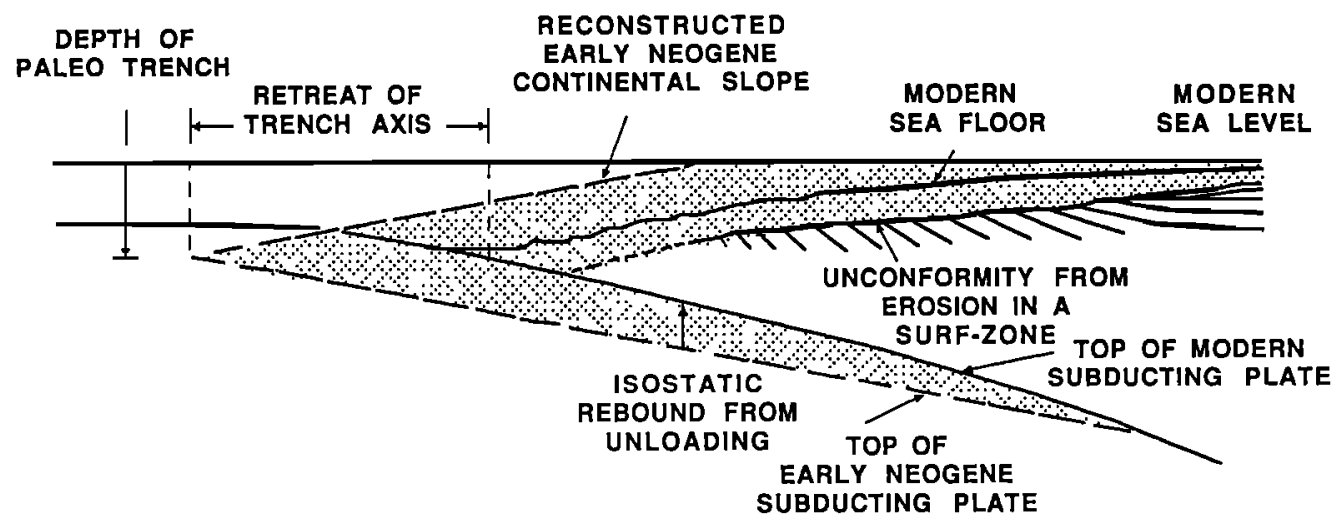

Figure 10. Diagram showing the method of measuring the rock and sediment volume removed by subduction erosion by comparing the contemporary and early Neogene structural configuration of an ocean margin. The area between modern sea level and a wave-base unconformity cut as the margin subsided beneath an ancient sea surface is a measure of the material removed from the margin. The weight of the eroded material was once compensated for by a deeper level to the top of the lower plate, which rose isostatically as the plate was unloaded. Missing material of the early Neogene margin is indicated by the pattemed area. 


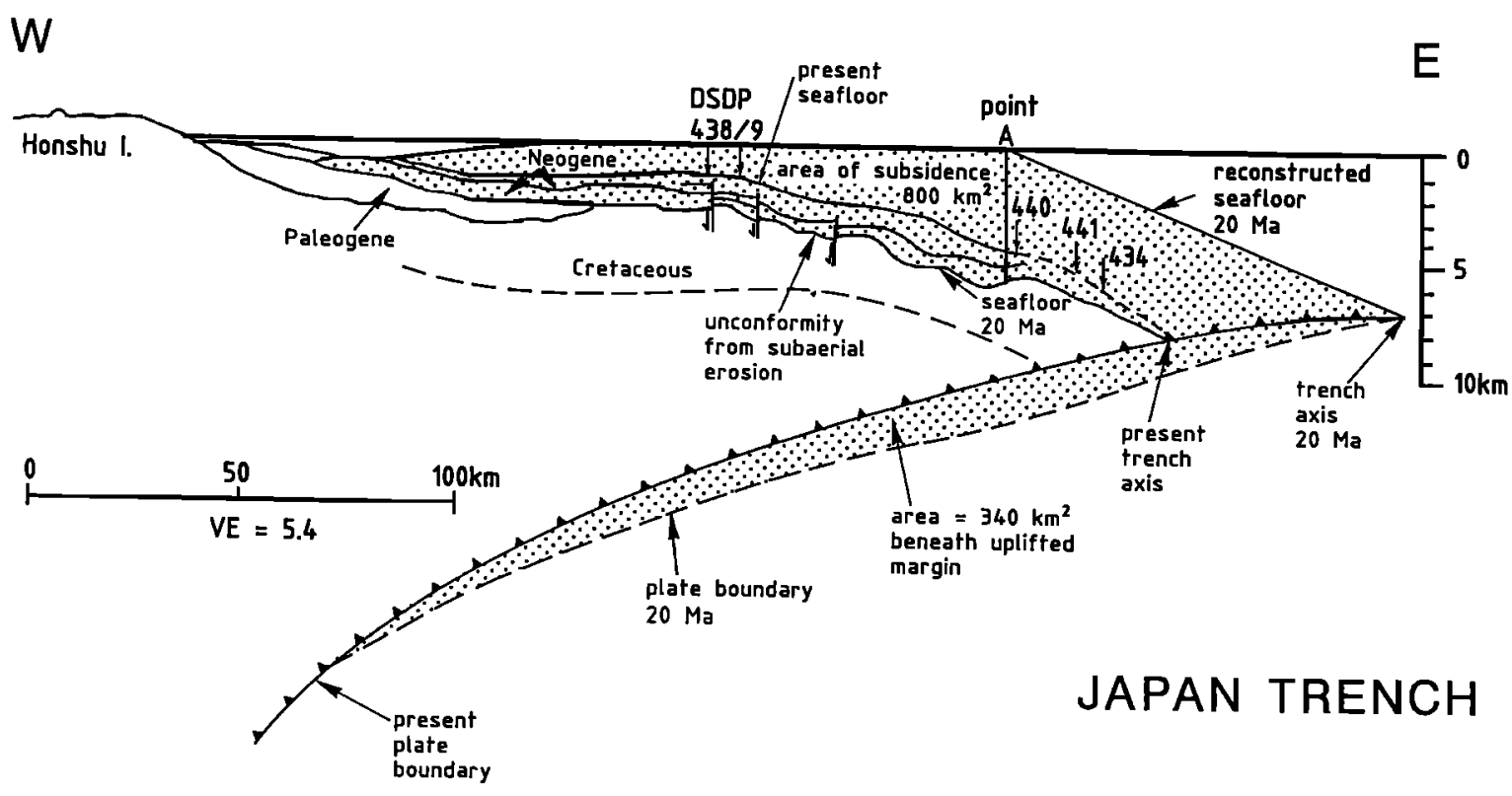

\section{PERU TRENCH Lima Basin area}

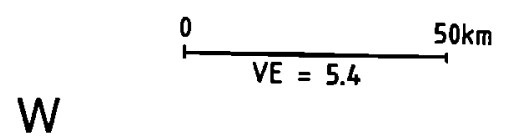

W

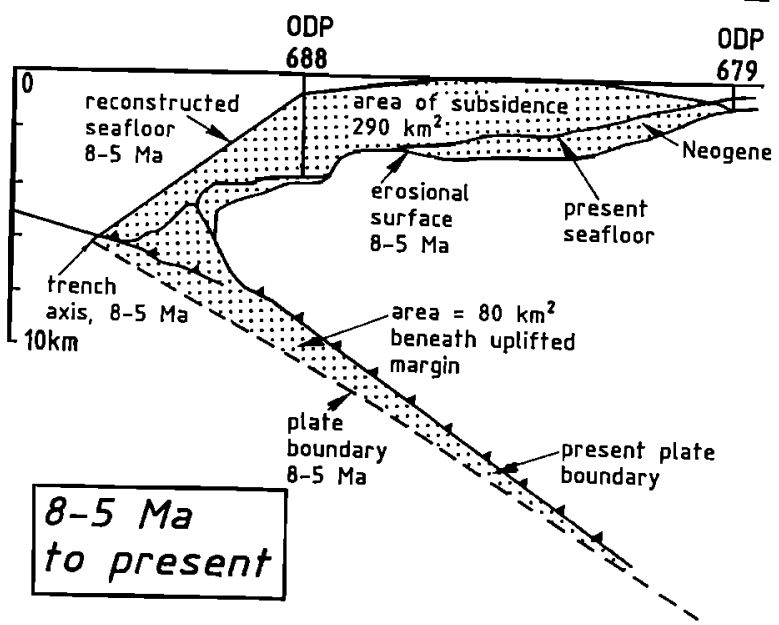

Figure 11. Diagrams showing the reconstructed (top) Japan and (bottom) Peru margins where a comparison of the reconstructed margins with the contemporary profiles was used to calculate the rate of subduction erosion during the past $20 \mathrm{~m}$.y. The amount of subsidence used to constrain the paleobathymetry was obtained from studies of ODP cores and industry drill samples tied to seismic stratigraphy. Quantities of missing material are expressed as $\mathrm{km}^{2}$ but can be read as volume in $\mathrm{km}^{3}$ per kilometer of margin. See Figures 8 and 12 for location of Japan and Peru data, respectively, and text for expanded explanation of methodology; data are from von Huene and Lallemand [1990]. 


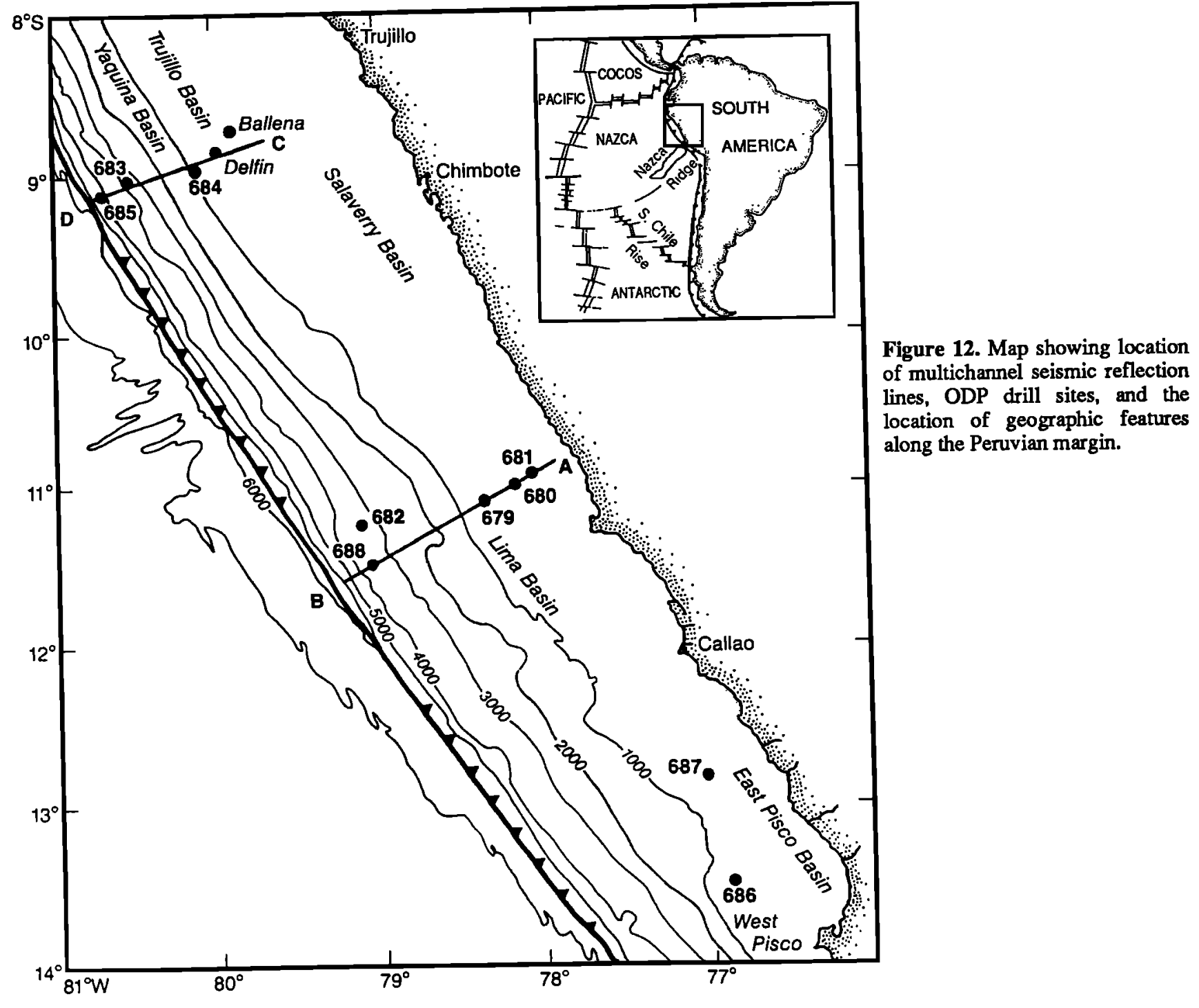

[Kulm et al., 1988]. The characteristic high acoustic velocity of these rocks allows them to be traced seaward beneath much of the margin.

In 1986, scientific drilling by the ODP established that beneath the landward trench slope the unconformity is immediately overlain by sandy, shallow-water deposits of middle Eocene $50 \mathrm{Ma}$ age [Suess et al., 1988]. These basal Paleogene beds are in turn unconformably overlain by a Neogene section of chiefly middle Miocene (15 Ma) and younger strata that accumulated in deeper water, thus testifying to erosion at wave base succeeded by margin submergence beginning about $20 \mathrm{Ma}$. The unconformity separating Neogene and Paleogene units is thus a sea level reference datum for a post-early Miocene marine transgression across much of the Peru margin [Suess et al., 1988; von Huene and Lallemand, 1990]. The transgressive surface can be traced seaward from the shelf edge to within $15 \mathrm{~km}$ of the trench axis. Rocks exposed on the seafloor flanking the Lima basin further document subsidence of the margin during the past $20 \mathrm{~m}$.y. [Kulm et al., 1988]. The subsidence history of the margin has been complicated during the past 10 m.y. by an episode of uplift and subsidence. This cycle of vertical tectonism is roughly concurrent with the time of subduction of the Nazca Ridge, a large submarine mountain range underthrusting the Peruvian margin (Figure 12) [von Huene et al., 1988].

If all the subsidence is ascribed to subduction erosion, the volume of rock and sediment eroded and removed from the Peru margin can be estimated by comparing its former cross-sectional mass with that remaining (Figure 11). The total subsidence, compensated for isostatic unloading, requires the removal of a rock mass along each kilometer of margin equivalent to $610 \mathrm{~km}^{3} / \mathrm{yr}$ during the past $20 \mathrm{~m}$.y. and $370 \mathrm{~km}^{3} / \mathrm{km}$ of margin during the past $8 \mathrm{~m} . \mathrm{y}$., which includes the time of subduction of the Nazca Ridge. The corresponding rates of erosion are respectively 31 $\mathrm{km}^{3} / \mathrm{m}$.y./km and $46 \mathrm{~km}^{3} / \mathrm{m}$.y./km. During subduction of the Nazca Ridge the rate of erosion local to the ridge may have effectively doubled over that of the previous $12 \mathrm{~m} . \mathrm{y}$. (i.e., from 20-8 Ma the rate was only $20 \mathrm{~km}^{3} / \mathrm{m} . \mathrm{y} . / \mathrm{km}$ ). Along the Peru margin at a convergence rate of about 90 $\mathrm{km} / \mathrm{m}$.y. the required average thickness of the subducted 
detritus during the past $8 \mathrm{~m} . \mathrm{y}$. is $0.5 \mathrm{~km}$ [von Huene and Lallemand, 1990]. To the material eroded from the Peru margin, a volume rate of subducted sediment of approximately $50 \mathrm{~km}^{3} / \mathrm{m}$.y. for each kilometer of margin must be added (Table 2). During subduction of the Nazca Ridge the total solid-volume passage of terrigenous material within the subduction channel was thus nearly 100 $\mathrm{km}^{3} / \mathrm{m}$.y., and the corresponding thickness of the subducting layer beneath the margin's core rock framework roughly $1 \mathrm{~km}$.

Farther to the south, in the vicinity of $46^{\circ} \mathrm{S}$ latitude, seismic reflection studies over the landward slope of the Chile Trench reveal a seaward depressed unconformity cut across continental crust of Paleozoic and Mesozoic age rocks (Figure 5) [Bangs et al., 1989; Cande et al., 1988]. The unconformity has been traced seaward from the shelf edge to within a few kilometers of the trench axis. Although not yet confirmed by drilling (but to be carried out in 1992), it is likely that the unconformity records massive thinning of the rock framework of the southern Chile margin by basal erosion, probably at least to the extent documented off Peru, (S. Cande, N. Bangs, and S. Lewis, personal communications, 1990).

\section{Mechanisms of Basal Erosion}

Basal erosion, in some fashion, wears away the base of the upper plate. Acoustic images of the eroded structure are difficult to recognize, but a likely example of a truncated structure was recorded along the Japan margin. Near the front of the upper plate the landward dipping fabric of a paleoaccretionary wedge is truncated at the plate boundary (Figure 13) [von Huene and Culotta, 1989]. Subsidence of the tectonic block containing the fabric has occurred during the past 2 m.y., a time during which basal subduction erosion actively thinned the upper plate.
The process of basal erosion along the Japan margin has been ascribed to the high-stress abrasive or scraping action of the landward moving and rough surface of the subducting plate [Hilde, 1983]. But, as noted, the relief of the underthrusting horst and graben topography is buried at the base of the trench landward slope, and the decollement forms 1-2 km above horst and graben structures, thus making it unlikely that abrasive erosion occurs. Similarly, Shipley and Moore (1986) remark that off Costa Rica basement ridges passing beneath the base of the landward slope of the Middle American Trench are covered by a layer of pelagic and hemipelagic ocean basin deposits sufficiently thick to buffer abrasive contact between the two plates. Beneath the margin's outer rock framework, the absence of large earthquakes [Yoshii, 1979] and the occurrence of little deformed subducting sediment (Figure 13) further imply that basal erosion occurs in an environment of low- rather than high-interplate friction. Thus erosion processes requiring strong coupling and mechanical abrasion are not appealing explanations for basal erosion along the outer part of the Japan and similar margins. Further inboard, however, where interplatecontact earthquakes occur, erosion may take place in high-stress environments.

A low-friction mechanism of basal erosion was proposed by Murauchi and Ludwig [1980]. These authors imagined a piecemeal stoping (an underground mining processes) of material from the underside of the upper plate. Stoping was thought to involve overpressured pore fields released from subducted sediment that migrate upward and disaggregate the base of the upper plate [von Huene and Lee, 1982; Platt, 1989]. Elevated pressures can also cause hydrofracting of rocks in the upper plate [Platt. 1989]. Traction plucking along the low-stress environment of the plate boundary can create a slurry of water and small

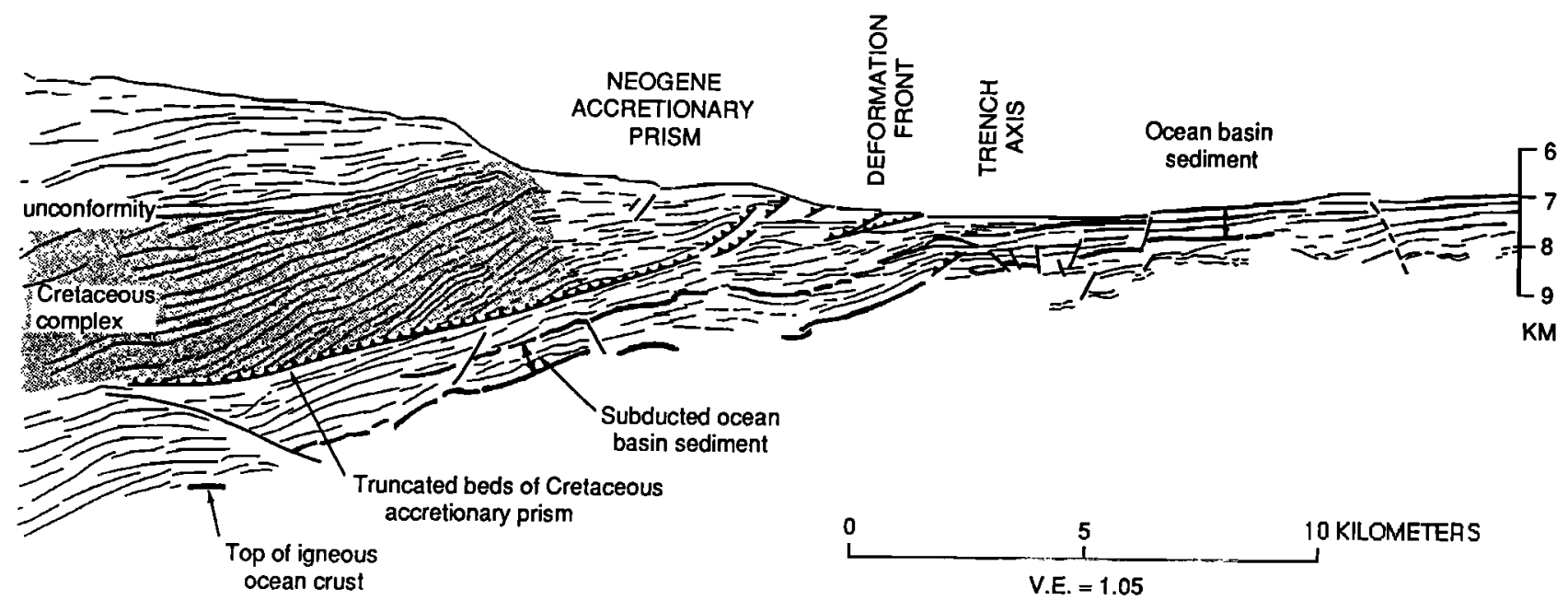

Figure 13. Line drawing of a seismic depth section across the Japan Trench where the structural or depositional fabric of older sedimentary rocks has been truncated above the subducting oceanic plate. Truncation is ascribed to subduction erosion along the base of the upper plate [von Heune and Cullotta, 1989]. Location of section at eastem end of seismic line ORI-78-4, Figure 8. 
rock fragments moving along the subduction channel beneath the buttress [von Huene and Lallemand, 1990]. Individual blocks or fragments that have been loosened by basal erosion or are in the process of being transported landward, are probably too small to be imaged by conventional reflection techniques. The hypothetical subduction slurry would probably appear acoustically similar to a layer of subducted sediment. An overpressured interplate environment can also cause plate boundary shear planes to move upward, thereby attaching slabs of the margin's framework rock to the underthrusting lower plate. Conceivably, these upper plate slabs could be acoustically imaged, but distinguishing them from other "layerlike" rock masses in the shear zone of the plate boundary would be difficult [see Calvert and Clowes, 1990]. Shreve and Cloos [1986] and Cloos and Shreve [1988a, b] more fully discuss the physical environment of the subduction channel that promotes subduction erosion.

\section{Mechanisms of Frontal Erosion}

Deep-sea dredging has established that framework rock is exposed along the landward slopes of nonaccreting trenches, an observation commonly cited as documenting the effects of frontal erosion [Bloomer, 1983; Bloomer and Fisher, 1988]. Initially, processes of frontal erosion, like basal erosion, were visualized as a consequence of the abrasive action of the underthrusting horst and graben topography. Underthrusting ridge crests were thought to cut off the front of the upper plate and deliver the resulting debris into the trench, from which it was removed as part of the material filling the troughs of underthrusting grabens [Schweller and Kulm, 1978; Hilde and Sharman, 1978; Schweller et al., 1981]. However, seismic reflection profiles and bathymetric data show that the relief of underthrusting horsts are not like the sharp teeth of a chainsaw but rather are broad ridges bordered by gentle slope $\left(5^{\circ}\right.$ to $\left.15^{\circ}\right)$ and topped by weakly consolidated oceanic basin sediment [Shipley and Moore, 1986]. As emphasized, where these sedimentary sections enter the subduction zone, overpressured conditions form and frictional coupling between the two plates is greatly reduced.

Along nonaccreting margins and even along some with medium-sized accretionary piles, the passage of ocean floor horsts and grabens beneath the margin cyclically elevates and lowers the base of the trench slope [McCarthy and Scholl, 1985; Moore et al., 1986; Shipley and Moore, 1986]. This process of tectonic rippling is envisioned as fracturing and therefore weakening the rock and sediment sequence of the lower slope. But, more importantly, at poorly sedimented and nonaccreting margins the underthrusting horsts will be bordered by unfilled grabens that should cause gravity failure of the lower landward trench slope as they pass beneath its base [Ballance et al. 1989]. Unfortunately, owing to the limited resolving power of contemporary reflection techniques, this supposition has not been confirmed where ridges and valleys of relatively low relief $(-500 \mathrm{~m})$ underthrust the inner trench wall. Evidence that frontal erosion is caused by the subduction of bathymetric relief has therefore to be sought where seafloor features large enough to be imaged well, for example, major seamounts and oceanic ridges, enter subduction zones.

The tectonic consequence of the collision of a seamount with an inner trench "wall" has long been a fascinating consideration, no doubt because the idea conjures images of a calamitous tectonic event. But, like the chainsaw model of horst and graben subduction, the drama of colliding trench walls and seamounts is much enhanced by the high vertical exaggeration commonly used (typically 5-10:1) to illustrate physiographic features on the ocean floor. A vertically exaggerated seamount appears impossibly high for the continental slope to accommodate, thus conveying the incorrect notion that seamounts are seldom subducted but sheared off, smashed, and accreted to the margin in small bits.

In the late 1970 s, using conventional or ship track sounding profiles, a partially subducted seamount, Daiichi-Kashima, was discovered along the axis of the Japan Trench (Figure 8) [Mogi and Nishizawa, 1980]. Advanced or areal swath mapping techniques were subsequently employed to define the morphology of the seamount in much greater detail (Figure 14) [Oshima et al., 1985; Kobayashi et al., 1987]. Daiichi-Kashima is cut by steeply dipping extension faults that extend toward it from the adjacent oceanic crust. Tension faulting across the seamount and the surrounding ocean floor occurs in response to the downward flexing of the oceanic plate toward the trench axis [Fyrer and Smoot, 1985; Fyrer and Hussong, 1985]. Off Japan, the impacting seamounts elevate and bulge the lower trench slope, disrupting the downslope continuity of a drainage system of small submarine canyons that formally led to the trench floor. Seismic reflection records show that at the impact site, thrust faults and tilted strata have thickened the sediment and rock of the inner trench wall, but the structure of the underriding seamount is basically intact [Lallemand et al., 1989].

Bathymetric swath-mapping farther to the north has revealed other seamounts at various stages of underthrusting (Figure 8). The initial stage is observed at Katori seamount (immediately north of Daiichi-Kashima), whose leading flank has narrowed and elevated the trench floor (Figure 14). Extension faults initially propagated across the seamount where it crossed the zone of maximum crustal flexure just seaward of the trench axis. The initial stage, where the leading flank of the seamounts is beginning to be wedged beneath the base of the trench slope, is illustrated in Figure $15 a$.

From the crest to the base, the overall slope angle of the subducting Japanese seamounts is about $15^{\circ}$. The underthrusting action of these large edifices wedges up, deforms, and therefore presumably fractures the base of the trench slope (Figure 15b) [Lallemand and Le Pichon, 1987]. 

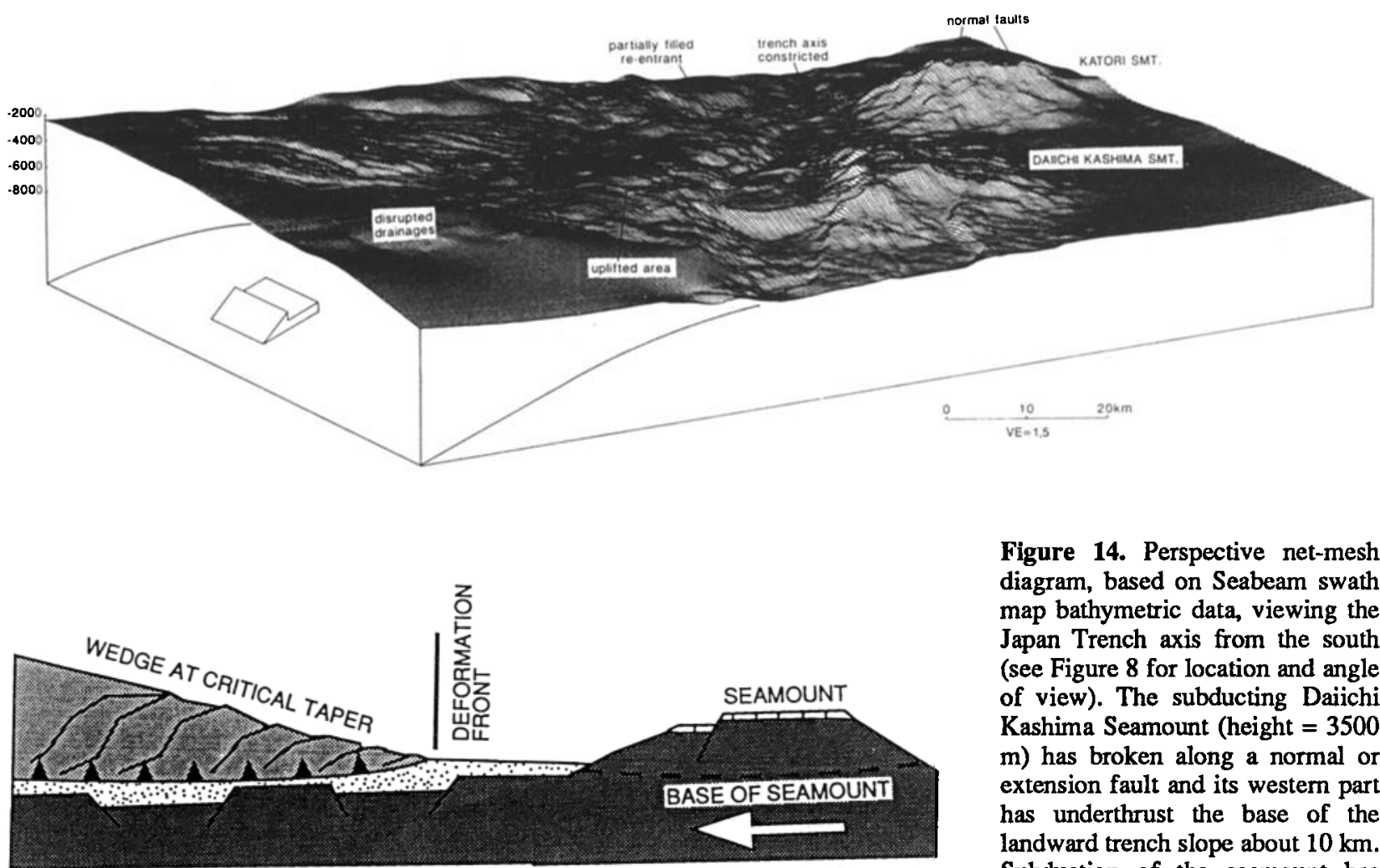

Figure 14. Perspective net-mesh diagram, based on Seabeam swath map bathymetric data, viewing the Japan Trench axis from the south (see Figure 8 for location and angle of view). The subducting Daiichi Kashima Seamount (height $=3500$ $m$ ) has broken along a normal or extension fault and its western part has underthrust the base of the landward trench slope about $10 \mathrm{~km}$. Subduction of the seamount has uplifted and disrupted sediment drainage patterns on the continental slope. The slope has retreated where the seamount is being subducted. A stage prior to initial subduction is seen to the north where Katori Seamount is entering the Japan Trench (Figure 8). Opposite Katori Seamount is a partially filled reentrant that may be the scar of a previously subducted seamount.

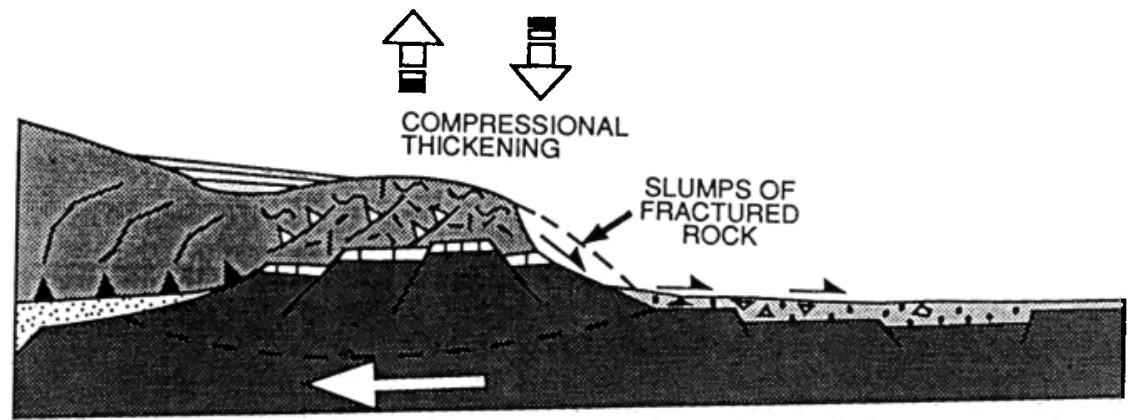

Figure 15. Cross sections illus-

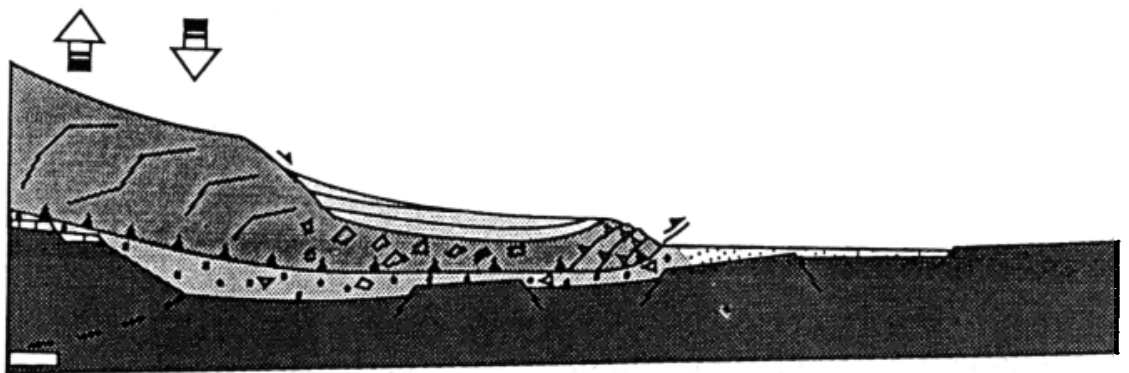

trating the progressive response of the continental slope to the subduction of a seamount. The net result of which is the accelerated subduction erosion of the frontal region of the continental margin. 


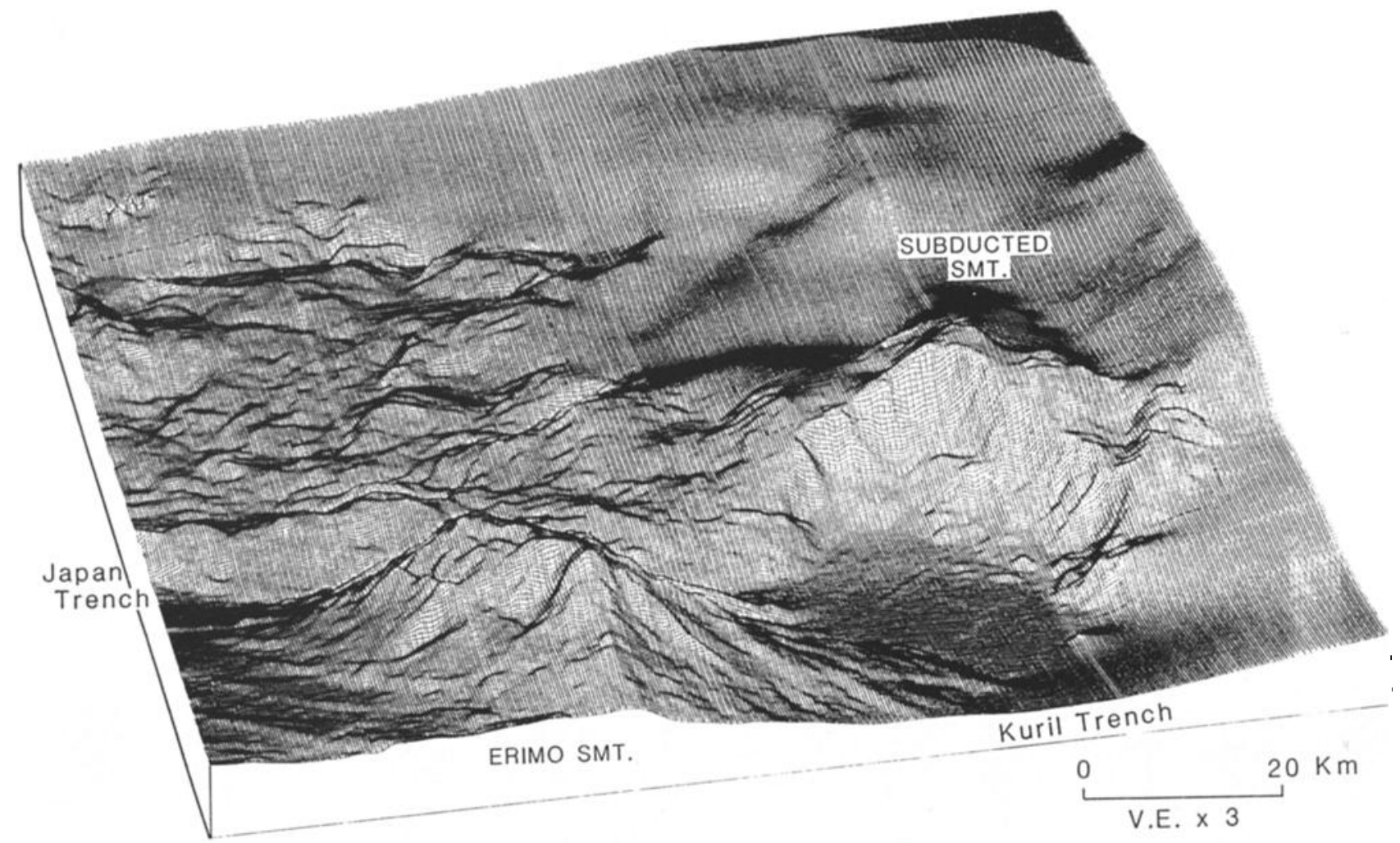

Figure 16. Juncture of the Japan and Kuril Trenches, viewed from the east in a perspective diagram constructed from Seabeam swath mapping over the continental slope and trench region and conventional bathymetric techniques, i.e., data collected only directly beneath the surveying vessel, over the shelf (see Figure 8 for location). The reentrant north of Erimo Seamount is an erosional scar or "cookie bite" in the lower landward trench slope made by the passage of a subducted seamount, which presently underlies the uplifted part of the adjacent slope. Within the reentrant are topographic blocks of slope-failure debris that contrast with areas of flat-lying sea floor underlain by the more fluidized debris of avalanche deposits. Linear extension faults paralleling the Kuril Trench cut across Erimo Seamount and the adjacent sea floor.

Because the slope of the inner trench wall is typically at a critical angle of gravitational stability [Nasu et al., 1980; von Huene and Culotta, 1989], the weakened material underlying the bulge responds to steepening by failing in gravity-driven slides. As the trailing flank of the seamount moves beneath the slope, the thickened welt of fractured and deformed rock piled up over the crest of the seamount collapses down a descending slope toward the trench floor [von Huene and Lallemand, 1990].

Evidence that impacting seamounts accelerate the removal of material from the front of the margin is provided by the existence of reentrants, "cookie bites," or scallops along the base of the inner trench wall (Figure 16) [Lallemand and Le Pichon, 1987; Collot and Fisher, 1989; Ballance et al., 1989]. Reentrants form where seamounts have passed beneath the landward trench slope. For example, a large reentrant at the juncture of the Japan and Kuril trenches marks the point where a large seamount landward of Erimo Seamount has been completely subducted (Figures 8 and 16) [Lallemand and ChamotRooke, 1986, Yamazaki and Okamura, 1989]. Although some of the material of the reentrant is probably shouldered aside and remains on the trench wall, an important fraction is thought to be missing, having collapsed to the trench floor to be either accreted or subducted. The mass-wasting material either forms structureless debris piles or, where sufficiently fluidized, trench axis deposits. The formation of the reentrant in the wake of the underthrusting seamount implies that the bulk of both accumulations are removed by subduction processes.

Because a small accretionary prism underlies the landward slope of the Japan Trench, it seems likely that some of missing material is reaccreted and some is introduced into the sediment subduction process. But the reentrant scars are deep enough to reach the margin's inner or core rock framework. Conceivably, farther landward, the subcrustal passage of a seamount locally elevates the plate boundary (i.e., position of the decollement) and accelerates basal erosion of the margin's core buttress as well [Ballance et al., 1989].

Along nonaccreting margins the existence of seamountimpact scars is strong evidence for the localized accelerated frontal erosion of the margin. For example, seamount 
subduction appears to have removed mostly framework rock and slope deposits from the landward slope of the New Hebrides Trench [Collot and Fisher, 1989]. Also, in the southwestern Pacific the collision of the Louisville Ridge at the nonaccretionary Tonga Trench is associated with a reentrant of large proportions that bites deeply into the arc framework rocks of the Tonga Ridge (Figure 17).

The collision zone of the Louisville Ridge and the Tonga Trench lies at the southern end of one of Earth's greatest depressions, Horizon Deep at $10,800+m$, and a 50-km-wide and 450-km-long landward deflection in the trench axis, Horizon-Deep bight (Figure 17) [Fisher, 1954; Lonsdale, 1986; Ballance et al., 1989; Pelletier, 1989]. Near the trench the ridge is constructed of a northwest trending series of large seamounts and plateaulike edifices that rise $2-3 \mathrm{~km}$ above a broad bathymetric swell. These structures collide with the trench in a direction virtually orthogonal to its northeast strike. Seismic sections appear to document that seamounts of the Louisville chain are subducted virtually in toto [Ballance et al., 1989]. The speed of collision is exceptionally fast, roughly 170 $\mathrm{km} / \mathrm{m}$.y. and because the strike of the ridge is oblique to that of the trench, the collision point moves even more rapidly southward (Figure 17) [Pelletier and Louat, 1989; Pelletier, 1989; Pelletier and Dupont, 1990]. At the impact or collision point, the trench has been shallowed by nearly $4.5 \mathrm{~km}$ [Pointoise et al., 1986], the consequences of which has presumably been rapid uplift, internal deformation and
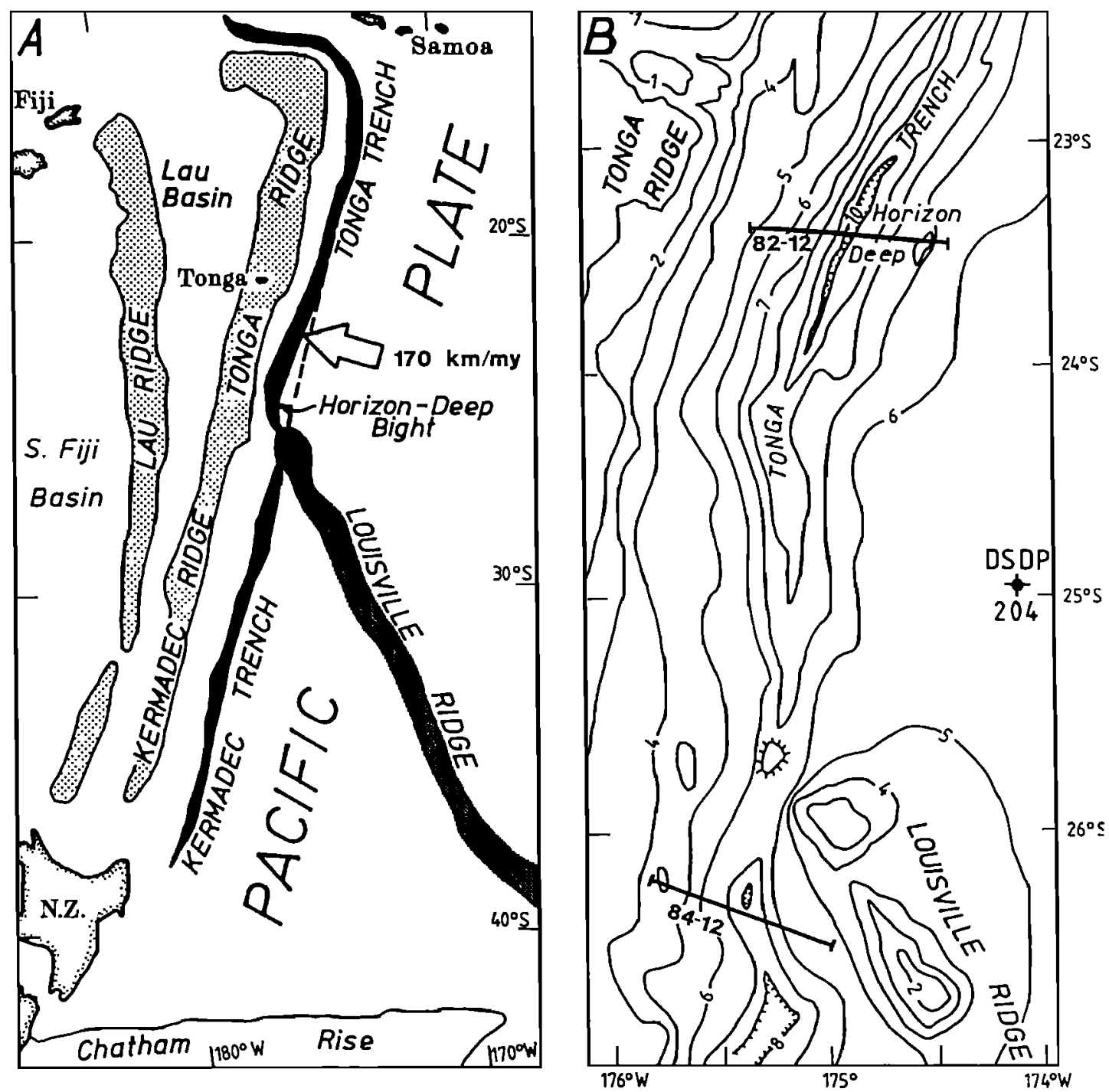

Figure 17. (a) Index chart of the southwestern Pacific, north of New Zealand (NZ), of the Tonga-Kermadec Ridge and trench system, and $(b)$ its collision zone with the Louisville Ridge of the Pacific plate. Because the trend of the rapidly underthrusting Louisville Ridge is oblique to that of the Tonga-Kermadec Ridge, the collision zone along the landward trench slope migrates even more rapidly southward. The Horizon-Deep bight, a tectonic reentrant in the regional trace of the trench axis, is thought to be prima facie evidence for the effects of subduction erosion enhanced by ridge-ridge collision [Ballance et al., 1989]. 
fracturing of the lower landward trench slope, and the sliding of oversteepened material into underthrusting grabens. Adjacent to the Tonga Trench, the dimensions of these depressions are uncommonly large, $3-5 \mathrm{~km}$ wide and 0.5-1.5 km deep [Lonsdale, 1986; Pelletier and Dupont, 1990]. The great size and length of the reentrant of the Horizon-Deep bight record not only accelerated subduction erosion but the effects of the rapid southward movement of the collision zone [Ballance et al., 1989; Pelletier and Dupont, 1990]. The lower landward slope is constructed substantially of basement rock exhibiting high acoustic velocities [Scholl et al., 1985]. Thus subduction erosion primarily removed arc framework rock at a rate at least $40-50 \mathrm{~km}^{3} / \mathrm{km} / \mathrm{m}$.y. above any regional or background rate.

On the eastern side of the South Pacific the Nazca Ridge collides with the Peru margin (Figure 12). As previously noted, subduction of the ridge has accelerated subduction erosion [von Huene et al., 1988; von Huene and Lallemand, 1990]. Although the collision zone migrates slowly southward, it is not trailed by an embayment cut by frontal erosion. Unlike the sediment-starved Tonga Trench, the Peru Trench receives sufficient sediment to support the growth of a moderate-size accretionary prism, which presumably has filled in the lower slope embayment subsequent to ridge subduction.

Farther to the south, at $46^{\circ} \mathrm{S}$, the South Chile Ridge, a spreading center that separates the south and central sectors of the Chile Trench (Figure 12), underthrusts the Chile margin. A major cusp in the regional trend of the trench axis is coincident with the collision zone, which migrates slowly northward [Cande and Leslie. 1986]. The floor of the southern Chile Trench is underlain by a thick wedge of terrigenous sediment, and, except in the vicinity of the collision zone, the lower slope is underlain by an accretionary pile [Cande and Leslie, 1986]. The absence of the pile where the ridge underthrusts the margin is strong evidence attesting to the efficacy of subduction erosion at this collision zone [Bangs et al., 1989]. Because the trench floor is well nourished by terrigenous sediment, rapid growth of the accretionary pile in the wake of the migrating collision zone has in part limited the width and length of its trailing tectonic scar. As previously noted, seismic data imply that basal subduction erosion has greatly thinned the margin's framework of Mesozoic and older igneous and metamorphic rock.

\section{CONTEMPORARY QUANTITIES OF ACCRETED AND SUBDUCTED SEDIMENT AND ASSOCIATED FLUIDS}

\section{Global Mass of Subducted and Accreted Sediment}

The global rate of contemporary sediment subduction can be estimated from the volume of trench floor sediment, that is, both ocean basin and axial trench deposits, that enters subduction zones but is not frontally accreted (Table 2). Present nonaccreting or type 2 trench sectors border roughly 19,000 linear $\mathrm{km}$ of ocean margin (Table 2). For each sector the contemporary or current rate of sediment subduction is the product of the average orthogonal convergence rate, the average solid-volume thickness of the trench floor section, and the length of the sector. At nonaccreting margins we estimate that the global average thickness of the dominantly pelagic and hemipelagic trench floor section is $0.4 \mathrm{~km}$ (range from 0.2 to $0.6 \mathrm{~km}$ ). Using Hamilton's [1976] porosity-versus-depth values for these sediment types and the data of Howell and Murray [1986], we set the equivalent solid-volume thickness of subducted sediment at $0.24 \mathrm{~km}$ (see Tables 2). By summing the volume rates listed on Table 2 (see also Figure 5) we estimate the contemporary global rate of sediment subduction at nonaccreting margins is $389 \times 10^{3}$ $\mathrm{km}^{3} / \mathrm{m}$.y., or $0.4 \mathrm{~km}^{3} / \mathrm{yr}$.

Where accretionary prisms form at type 1 margins, the thickness of the underthrusting or subdecollement section is commonly more than $1.0 \mathrm{~km}$. But seismic data measuring the thickness of the section actually being subducted (i.e., imaged passing beneath the active buttress) are sparse [Bally, 1983; von Huene, 1986]. For all type 1 margins we therefore, use mass balance considerations to estimate the contemporary volume of sediment underthrusting the actively accumulating frontal mass or that has been subducted landward of the active buttress (Figure $3 a$; Table 2). By averaging the data from the four bestcontrolled margin sectors (Japan, Mexico, Peru, and Alaska, includes Aleutians) we estimated earlier that about $20 \%$ of the sediment entering subduction zones fronted by small- to medium-sized prisms is frontally accreted and a minimum of $80 \%$ is subducted. We suppose that these partitioning factors are applicable to similar type 1 margins elsewhere. Over long periods of time the amount of material subducted at all accreting margins must be adjusted for higher Neogene rates of ocean floor sedimentation, a correction that tends to lessen the long-term rate at which sediment is subducted at type 1 margins (see below).

It can be presumed that efficient accretion (both frontal and underplating) takes place where large accretionary prisms have formed [Davis and Hyndman, 1989]. Examples of these prisms are found along the Sunda margin from Burma to Sumatra [Moore et al., 1980], the Makran margin of southern Iran and Pakistan [White, 1982; White and Louden, 1982], the Barbados margin of the Lesser Antilles [Westbrook et al., 1988; Mascle and Moore. 1990], the Manila margin of the Philippines [Lewis and Hayes, 1984; Hayes and Lewis, 1985], and the northern Cascadia margin off Vancouver, British Columbia, and northern Washington [Davis and Hyndman, 1989; Snavely and Wells, 1991] (Figure 5). These large, actively growing accretionary piles are identified on Table 2 as type $1^{*}$ margins.

Although the internal structures of large prism are difficult to image seismically, mass balance calculations require that for many of them volumetric growth is contributed by both frontal and underplating accretion 
[Platt et al., 1985; Platt, 1986, Ladd et al., 1990]. For example, at the Makran prism it can be inferred from mass balance considerations that the relative proportions of frontally accreted to subducted sediment (most of which underplates the prism) is roughly 1:2 [Platt et al., 1985]. At the northern Barbados margin, drilling and seismic information compiled by Brown et al. [1990] and Mascle and Moore [1990] establish that during the past 2 m.y. approximately $30 \%$ of the incoming section was frontally accreted and $70 \%$ is either underthrusting the frontal prism or has been subducted landward of the active buttress. Although we recognize that perhaps little underplating occurs within the large Vancouver prism [Davis and Hyndman, 1989], within-section decollements are prominent structures of most other large accretionary masses. For the large accretionary prisms we adopt a partitioning factor of $30 \%$ frontal accretion versus $70 \%$ sediment subduction.

The combined length of all sectors of accreting or type 1 margins is approximately $24,500 \mathrm{~km}$ (Table 2). The contemporary subduction rate for each sector is the product of the sector's average orthogonal convergent rate, the subduction partitioning factor applied to the thickness of the trench floor section, and the length of the sector. Using the appropriate porosity-depth curve of Figure 6, the measured thickness of the trench floor section is first shrunk to its zero porosity or solid-volume thickness. Summing the rates for each sector gives a contemporary global rate of $1138 \times 10^{3} \mathrm{~km}^{3} / \mathrm{m} . y$., or, in rounded figures, $1.1 \mathrm{~km}^{3} / \mathrm{yr}(0.7$ for type 1 margins with smaller prisms, 0.4 for type $1^{*}$ or large-prism margins; Table 2). Combining this rate with that for the nonaccreting or type 2 margins $(1.1+0.40$; Table 2$)$, provides a contemporary global rate of sediment subduction of $1.5 \mathrm{~km}^{3} / \mathrm{yr}$.

Correspondingly, the total solid-volume mass of sediment frontally accreted at all forms of type 1 margins is $0.4 \mathrm{~km}^{3} / \mathrm{yr}$. We present observations below that the bulk of the subducted sediment is stored as underplated sediment in the part of the accretionary prism lying between its active and core buttresses (Figures $3 a$ and 3c). The estimated mass of the underplated material boosts the total volume of offscraped sediment stored at accreting margins to $0.9 \mathrm{~km}^{3} / \mathrm{yr}$.

\section{Global Volume of Fluids}

Sediment that enters the subduction zone contains a porosity-equivalent volume of interstitial fluids. As the accreted sediment is thickened by thrust faulting and folding, fluids are squeezed from the sediment interstices and returned to the ocean basin. Fluids associated with underthrust sediment have been observed to vent by channelized flow seaward along the decollement [Mascle and Moore, 1990], to discharge a more distributed way via many fractures within overlying rock framework [Carson et al., 1982], discharge with upwelling masses of subduction channel sediment [Cloos and Shreve, 1988a], combine chemically or mineralogically with surrounding material, or be transported on the oceanic plate until they are absorbed into upper mantle rocks (see, for example, Peacock [1990]).

First-order estimates of the volume of fluids expelled from the frontally accreted mass can be based on the data in Table 2 and some simplifying assumptions. Accreted material dewaters as thickening of the accretionary wedge loads the underlying sediment and causes expulsion of its fluids; the resulting porosity profile looks more or less like that shown in Figure 6. As the size of the prism increases, the porosity profile shifts upward through the accreted section proportional to its growth. We assume that in the prism the porosity decreases to $10 \%$ at a depth of $3.5 \mathrm{~km}$, changing little below this level (Figure 6). Once the frontal accretionary body becomes sufficiently large so that its porosity profile extends downward to the $10 \%$ end of the gradient, the position of the gradient shifts upward equivalent to the addition of new trench sediment. Under conditions of a constant gradient shift the addition of sediment and fluid to the prism results in an expulsion of fluid equivalent to the added volume. Thus the rate at which pore fluid is expelled from frontal accretionary masses approximates the rate at which fluid is incorporated, less $10 \%$.

Similar approaches can be taken to estimate the volume of fluids expelled from subducted sediment, which either underplates or bypasses the prism. Subducted sediment and contained fluid travel below the prism from its front to depths exceeding about $10 \mathrm{~km}$ where hydrated metamorphic minerals of the greenschists and in particular the high-pressure blueschists facies form. As sediment and fluids move in a conveyor belt fashion along the subduction channel, a constant amount of fluid will be expelled. For sediment that deeply underplates the prism or the margin's rock framework, the volume expelled will be equal to that associated with this subducted sediment less an estimated $3 \%$ tied up in the growth of metamorphic minerals. But some subducted sediment will underplate the prism at higher structural positions and most likely retain pore fluids at about the $10 \%$ level. Because we cannot easily distinguish the relative quantities of these subducted masses, we assume an average retention of $5 \%$ fluid for the total mass of sediment subducted at all forms of type 1 margins. Similarly, we assign a 5\% retention to the mass of pore fluids subducted at nonaccreting margins or type 2 margins.

On the basis of the data assembled in Table 2 the total volume of fluid entering subduction zones is close to 1.0 $\mathrm{km}^{3} / \mathrm{yr}$. The rate of fluid expulsion is the frontally accreted volume less $10 \%$, or $0.1 \mathrm{~km}^{3} / \mathrm{yr}$, and the volume subducted less $5 \%$, or $0.8 \mathrm{~km}^{3} / \mathrm{yr}$. The combined volumes of expelled fluids is thus $0.9 \mathrm{~km}^{3} / \mathrm{yr}$. This volume is similar to that estimated by Working Group 3 during the Second Conference on Scientific Ocean drilling (COSOD II, 1987). Our simplistic assumption of steady state tectonism and fluid expulsion is in keeping with the difficulty of estimating fluid recycling from other sources, particularly 
from mineral transformation as sediment and igneous ocean crust is metamorphosed and also from fluids in the upper part of the underthrusting igneous slab. Our rough estimate of expelled pore fluids from accreted and subducted sediment is probably significantly supplemented by volumes from these other sources.

\section{LONG-TERM SUBDUCTION RATES OF TERRESTRIAL MATERIAL}

\section{Long-Term Rate of Sediment Subduction}

The contemporary volume of sediment subducted yearly at convergent margins $\left(1.5 \mathrm{~km}^{3} / \mathrm{yr}\right.$, Table 2$)$ is probably higher than that typical of most of Cenozoic time and arguably that typical of the past several hundred m.y. We recognized earlier that the trench sections of many type 1 or accreting margins are probably overly thick because of glacially elevated rates of deep-sea terrigenous sedimentation. Preglacial axial fills have been severely deformed or subducted thus affording little basis for reconstructing their former thicknesses. Referring as a guide to rates of ocean floor terrigenous sedimentation tabulated by Southam and Hay [1981], Sloan [1985], and Hay et al. [1988], we earlier estimated that prior to $2.5 \mathrm{Ma}$ the thickness of the trench section was about one half that of the contemporary or glacial-age thickness (Table 1).

For the purpose of estimating a long-term rate of sediment subduction, applying the $50 \%$ reduction may be an overcorrection. For example, many modern trench sectors are thickly sedimented as much for the reason that they are nourished by rivers draining rapidly elevating mountain ranges, for example, the trenches bordering the Sundra, Makran, Manila, and Alaska-Aleutian regions, as by the effects of glaciation. Elevation of the ranges is in response to convergent margin tectonism, in particular where masses of continental crust are colliding (for example, Himalaya, Taiwan, Gulf of Alaska regions). It is instructive to realize that $70 \%$ of the sediment discharged by rivers to ocean basins is from two regions of intense tectonic uplift linked to the collisions of India and Asia, and more diffusely, of Australia and Indonesia [Milliman and Meade, 1983; Dickinson, 1988; Meade, 1991]. Owing substantially to the India collision event alone, nearly $28 \%$ of all ocean basin terrigenous sediment resides in the Indian Ocean, the smallest of the three major oceans [Howell and Murray, 1986], and the supply of terrestrial debris needed to sustain the growth of the large accretionary prisms of the Makran and Andaman-Sunda trench systems has thus been maintained at high levels since at least the early Neogene [Curray and Moore, 1971; Beaudry and Moore, 1985; Copeland and Harrison, 1990]. Therefore many type 1 trench sectors probably sustained thick axial wedges before the sedimentation enhancing effects of glacially induced oscillating sea levels and heightened continental erosion.

In addition to directly supplying clastic sediment to the trench axis the consequences of both global climatic changes and major convergent margin tectonism have combined during the past $35 \mathrm{~m} . \mathrm{y}$. to irregularly but progressively increase the supply of terrigenous sediment to the ocean basins seaward of trenches [Davies et al., 1977; Worsley and Davies, 1979; Southham and Hay, 1981; Sloan, 1985; Hay et al., 1988]. The magnitude of the change was from an unusual global low of $0.5 \mathrm{~g} / \mathrm{cm}^{2} / 10^{3} \mathrm{yr}$ in the early Oligocene to about $2.5 \mathrm{~g} / \mathrm{cm}^{2} / 10^{3} \mathrm{yr}$ just prior to the onset of late Cenozoic glaciation and thence to nearly $4.0 \mathrm{~g} / \mathrm{cm}^{2} / 10^{3}$ yr [Sloan, $1985 ; W . W$. Hay, personal communication, 1990]. The average Neogene rate is roughly 2 $\mathrm{g} / \mathrm{cm}^{2} / 10^{3} \mathrm{yr}$ [Southham and Hay, 1981; Hay et al., [1988]. Glaciation therefore augmented an established trend of increasing terrigenous deposition that began in the early Oligocene.

Other uncertainties further hinder estimating the average long-term thickness of type 1 trench sections based on existing sections. These include the circumstance that ocean basin terrigenous input is in part regulated by trench axis overflow thereby precluding a direct relation between trench and ocean basin rates of sedimentation. In recognition of the uncertainty involved, and in an attempt to avoid overestimating the long-term rate of sediment subduction at type 1 margins, we halve the thickness of the modern trench section as was done in Table 1 . The long-term rate of sediment subduction at type 1 margins is thus set at 0.55 $\mathrm{km}^{3} / \mathrm{yr}$, which is one half the contemporary rate listed in Table 2.

The long-term subduction rate of the dominantly pelagic sediment at type 2 margins should be little different than the modern rate, $0.4 \mathrm{~km}^{3} / \mathrm{yr}$. Combining this rate with the trench-thickness-corrected rate for type 1 margins yields a global long-term rate of sediment subduction of 1.0 $\mathrm{km}^{3} / \mathrm{yr}$.

\section{How Good Are the Estimates?}

How well are the estimated volumes of subducted sediment constrained? Roughly $40 \%$ of the world's margins are nonaccretionary, and at these margins, sediment subduction is very efficient. Uncertainties of the subducted volume at these margins reflect inaccurate assessments of orthogonal convergence rates, and of the average thickness of the incoming blanket of ocean floor pelagic sediment and sediment deposited along the trench axis. In consideration of these factors our estimate of the contemporary volume of sediment subduction at type 2 margin are probably no better than $\pm 20 \%$ of the total 0.4 $\mathrm{km}^{3} / \mathrm{yr}$ noted.

Data used to estimate the proportions of sediment frontally accreted and subducted at all forms of type 1 margins are beset by the same measurement inaccuracies, and, in particular, by the assumption that during most of Cenozoic time the average thickness of the incoming section was only one half that presently entering these subduction zones. In constructing Table 1 we noted variabilities of $\pm 20 \%$ in calculating proportions of frontally accreted versus subducted sediment that arose from 
structural differences along various parts of the margin. Errors arising from the conversion of time-base seismic reflection data to depth in meters is also in the range of $\pm 10 \%$ at the median depths considered. Although it is difficult to accurately quantify, we feel that an error bar of at least $\pm 25 \%$ is applicable to our long-term rate of sediment subduction $\left(1.0 \mathrm{~km}^{3} / \mathrm{yr}\right)$ that includes calculations for both type 1 and type 2 margins.

Elsewhere below we estimate that the long-term rate at which subducted sediment bypasses the prism-accretionary process is $0.7 \mathrm{~km}^{3} / \mathrm{yr}$. It is instructive to compare this figure with the average one of Hay et al. [1988], 0.4 $\mathrm{km}^{3} / \mathrm{yr}$ (potentially as high as $0.5 \mathrm{~km}^{3} / \mathrm{yr}$ ), based on the mass of sediment in the deep ocean basins that subduction removes from the global store of sediment approximately each 180 m.y. The difference $\left(0.2-0.3 \mathrm{~km}^{3} / \mathrm{yr}\right)$ reflects principally the fact that our higher estimate includes subduction of axial turbidite deposits at both type 1 and type 2 trenches. These rapidly deposited masses are not included in the Hay et al. [1988] figure. At the present global average orthogonal convergence rate of approximately $65 \mathrm{~km} / \mathrm{m} . \mathrm{y}$. (Table 2 ), resolution of the 0.3 $\mathrm{km}^{3} / \mathrm{yr}$ difference requires on average the bypass subduction of a 100-m-thick (solid-volume) section of axial deposits. The thinness of this section supports our conjecture that our long-term rates of sediment subduction and bypassing are conservative or low-end estimates.

\section{Long-Term Rates of Subduction Erosion}

As described, measured subsidence along the Japan and Peru margins requires subduction erosion during the past $20 \mathrm{~m} . y$. at the respective rates of 55 and $30 \mathrm{~km} / \mathrm{m}$.y. per kilometer of trench (Figure 11) [von Huene and Lallemand, 1990]. Accepting that the porosity of the margin's rock framework, which off Japan is known to include sedimentary rocks, is approximately $10 \%$ yields a conservatively estimated solid-fraction volume of eroded rock of 50 and $25 \mathrm{~km}^{3} / \mathrm{km} / \mathrm{m}$.y. per kilometer of trench.

The Andean margin of northem Chile has been a sediment-starved or type 2 margin during much of Cenozoic time. Rutland [1971] notes that since the early Jurassic the axis of arc volcanism in northem Chile has progressively shifted inland more than $200 \mathrm{~km}$ and that this shift most likely records the landward migration of the
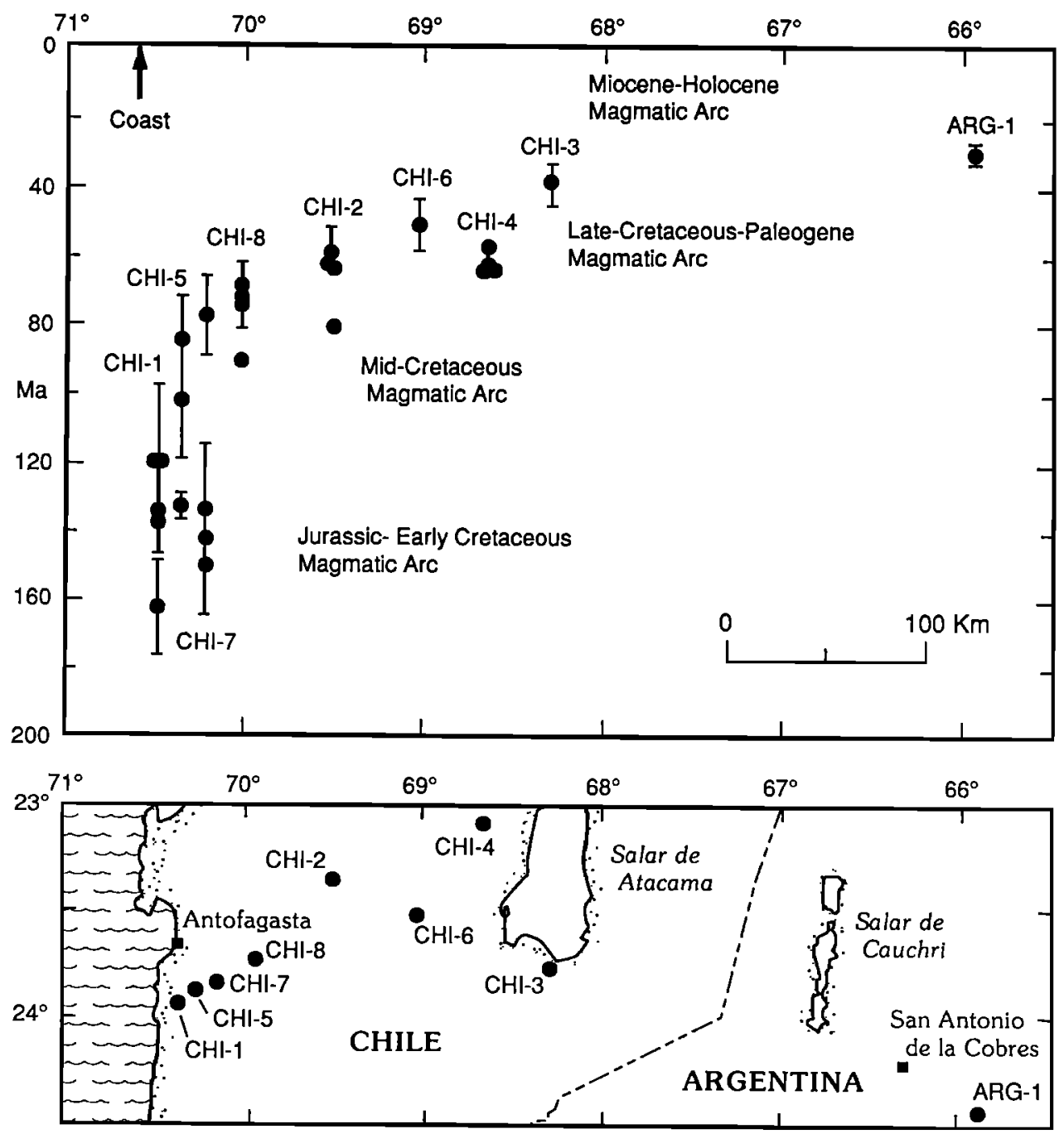

Figure 18. Plot of radiometric ages and sampling localities of arc igneous rocks from coastal ranges of northern Chile eastward to the Cordillera Oriental of the Andes (figure adapted with permission from Andriessen and Reutter, 1991]). Demonstrated eastward shift of the locus of arc magmatism is commonly cited as evidence for the subduction-erosion-caused eastward truncation of the landward slope of the Chile Trench during the past 160-180 m.y. [see Rutland, 1971; Scholl et al., 1977; Mpodozis and Ramos, 1990; Stern, 1991]. 
trench axis in response to subduction erosion. Applying the same reasoning, Mpodozis and Ramos [1990] indicate an eastward retreat of the Mesozoic trench beginning at the latitude of Conception $\left(38^{\circ} \mathrm{S}\right)$ and increasing to $300 \mathrm{~km}$ at the northern Chilean border (Figure 18). An castward shift from the position of the Mesozoic magmatic arc to the late Cenozoic arc is also documented in Peru [McKee and Noble, 1990]. North of the Nazca Ridge the contemporary arc is inactive, but the upper Miocene arc, exposed in the Andes, indicates a similar eastward migration since the Cretaceous. Part of the Cretaceous arc is inferred off the coast of central Peru [Thornburg, 1985] where it projects from onshore exposures to a basement ridge along the edge of the shelf. Although an eastward migration of the continental margin is indicated north of Peru, the lateral migration of large continental blocks since the Mesozoic precludes a simple linkage of eastward migration to subduction erosion.

In northern Chile the early Jurassic arc between $22^{\circ}$ and $27^{\circ} \mathrm{S}$ latitude is approximately $180 \mathrm{Ma}$ old (see, for example, Naranjo et al. [1986], Rogers and Hawkesworth [1989], and Andriessen and Reutter, [1991]. Averaging the width of the wedge shaped area of retreat indicates that an average eastward directed truncation of the margin proceeded at a rate of about $1 \mathrm{~km} / \mathrm{m}$.y. Ascribing eastward trench migration mostly to subduction erosion and presuming that during the past 180 m.y. the crustal geometry of the South American margin has remained much the same, then for each kilometer of margin approximately $7000 \mathrm{~km}^{3}$ of rock have been removed (crustal thickness of $38-\mathrm{km} \times 185-\mathrm{km}$ average distance of retreat). Dewey and Windley [1981] also calculate a mass loss of $7000 \mathrm{~km}^{3} / \mathrm{km}$ for this margin. Assuming a porosity of $10 \%$, the corresponding average rate of subduction erosion during the past $180 \mathrm{~m} . \mathrm{y}$. is $35 \mathrm{~km}^{3} / \mathrm{yr}$. Calculating somewhat differently, but drawing on the same basic observations, Stern [1991] reckons that subduction erosion may have proceeded at more than twice this rate and, periodically, at more than 10 times.

The rate of erosion since Mesozoic time for the Peruvian marginal segment estimated from the eastward shift of the arc (average crustal thickness of $38-\mathrm{km} \times$ $200-\mathrm{km}$ retreat) indicates erosion at a solid-volume rate of $30 \mathrm{~km}^{3} / \mathrm{m}$.y. along each kilometer of the margin. This rate is higher than that estimated for the past 20 m.y. (25 $\mathrm{km}^{3} / \mathrm{m} . \mathrm{y}$. ) by von Huene and Lallemand [1990], which indicates that the minimum estimate from their margin reconstruction is indeed low, or it may indicate more rapid erosion in pre-Neogene time. However, in view of the uncertainties involved in all these estimates, we assume a conservative long-term rate of $30 \mathrm{~km}^{3} / \mathrm{m}$.y. for each kilometer along the Peruvian and northern Chilean margins. The higher rates recorded along the Japan margin, where the Louisville Ridge intersects with the Tonga Trench, and along the Peruvian margin during subduction of the Nazca Ridge, are peak rates more typical of accelerated erosion rates caused by crustal collision. The estimated total net amount of erosion along $4500 \mathrm{~km}$ of Peru and central and northern Chile (Figure 18) contribute $0.13 \mathrm{~km}^{3} / \mathrm{yr}$ alone to the solid volume of terrestrial material that is subcrustally subducted.

Evidence was previously cited that subduction erosion operates at convergent margins other than Japan, Peru and Chile [Hussong and Uyeda, 1982; Bloomer, 1983; Bloomer and Fisher, 1987, 1988; Ballance et al., 1988]. Most are sediment-starved margins with little if any accretion and margins fronted by small-to-medium sized accretionary prisms, many of which are geologically young if not ephemeral bodies [Scholl et al., 1987; Moore et al., 1986]. As true of southern Chile, information from these margins is insufficient to determine long-term rates of subduction erosion (see, for example, Ballance et al. [1989]).

Recognizing the large short-fall in well-constrained erosion rates, we explore the possible global magnitude of subduction erosion applying an assumed average long-term rate of $30 \mathrm{~km}^{3} / \mathrm{km} / \mathrm{m}$.y. For example, if the rate is applied to the length of sediment-starved or type 2 trenches $(\sim 19,000 \mathrm{~km}$; table 2$)$, the global rate of erosion is 0.6 $\mathrm{km}^{3} / \mathrm{yr}$. If subduction erosion also affects the approximately $16,000 \mathrm{~km}$ of margins bordered by prisms of small-to-medium width, then an additional $0.5 \mathrm{~km}^{3} / \mathrm{yr}$ can be added for a global total of $1.1 \mathrm{~km}^{3} / \mathrm{yr}$. Subduction erosion may also have operated intermittently where large accretionary prisms have accumulated, but we have little information bearing on that possibility. The consequences of these various scenarios for the total amount of terrestrial crust eroded by subduction are summarized in Table 3.

TABLE 3. Global Long-Term Rate of Subcrustally Subducted Terrestrial Material

\begin{tabular}{lccc}
\hline & \multicolumn{2}{c}{ Subduction Erosion } & \\
\cline { 2 - 3 } $\begin{array}{l}\text { Subducted } \\
\text { Sediment }\end{array}$ & $\begin{array}{c}\text { At Type 2 or } \\
\text { Moccreting } \\
\text { Margins }\end{array}$ & $\begin{array}{c}\text { Wyph I Margins } \\
\text { Wedium-Sized Prisms }\end{array}$ & Tolal, $\mathrm{km}^{3} / \mathrm{yr}$ \\
\hline 0.7 & 0.6 & $\begin{array}{c}\text { Scenario 1 } \\
0.0\end{array}$ & 1.3 \\
0.7 & 0.6 & $\begin{array}{r}\text { Scenario 2 } \\
0.5\end{array}$ & 1.8 \\
\hline
\end{tabular}

Rate in $\mathrm{km}^{3} / \mathrm{yr}$.

\section{SOME COMMENTS ON SUBCRUSTALLY SUBDUCTED TERRESTRIAL MATERIAL AND THE GROWTH OF CONTINENTAL CRUST}

Although ocean margin tectonism is a highly effective process in laterally moving and assembling existing bodies of crustal material, these terrane-shuffling processes neither add nor subtract from the global mass of terrestrial crust (i.e., continents plus island arcs; see, for example, Coney et al. [1980], Jarrad [1986b], Howell [1989a], and 
Beck $[1983,1986])$. New or juvenile continental crust is formed by mantle-sourced igneous activity. Many authors emphasize that the dominant mechanism supplying juvenile crust is arc magmatism, assisted by lesser contributions from hotspot volcanism, intracontinental volcanism and magmatic underplating, and the accretion of slabs of oceanic crust (see, for example, Kay [1980], Thorpe et al. [1981], Reymer and Schubert [1984, 1986], Arndt and Goldstein [1989], Klemperer [1989], and Rogers and Hawkesworth [1989]). But, as we noted in our introductory comments, terrestrial material can potentially be lost at convergent margins.

Terrestrial material that is removed from the upper plate by subduction erosion, or oceanic sediment that bypasses the prism and underthrusts the margin's rock framework, can be tectonically transported to great depths (>15 km or more). Material transported beneath the margin's rock framework is referred to in this paper as subcrustally subducted matter. At type 2 margins, where long-lasting prisms do not form, virtually all of the volume of subducted sediment is available for transport to deep subcrustal levels. At type 1 margins, however, large masses of subducted sediment underplate the prism between its active and core buttresses. But rough estimates can be made of the portion of the incoming ocean floor section that is retained in the accretionary prism and that which bypasses it to reach subcrustal levels.

For example, where small-to-medium sized prisms front type 1 margins, we estimate from seismic data and the mass balance calculations of Table 1 that roughly $65 \%$ $( \pm 20 \%)$ of the incoming section bypasses these prisms. Because only about $20 \%$ is stored in the frontal accretionary mass, an additional $15 \%$ must nourish the prism's volumetric growth by underplating processes (Figure 3a). Bypassing at large prisms is apparently much less. Mass balance figures provided by Platt et al. [1985] for the Makran prism indicate that during the past $13 \mathrm{~m} . \mathrm{y}$. approximately $30 \%$ of the incoming section was used to build the frontal prism, $60 \%$ underplated the prism, and potentially $10 \%$ bypassed the prism. For the Barbados region of the Lesser Antilles, mass balance calculations based on the seismic sections of Westbrook et al. [1988] and Ladd et al. [1990] and regional information concerning the time-average thickness of the incoming section [Moore et al., 1990] indicate that bypassing of the 50-to 55- $\mathrm{m}$.y.-old accretionary prism ranges from effectively zero to as much as several tens of percent. Similarly, for the Vancouver prism of British Columbia, mass balance numbers support a bypassing figure of virtually nil [Davis and Hyndman, 1989] to as much as 30\% of the incoming section (our calculations). The variability for this prism arises from the range in average porosity that can be assigned to the accretionary prism, different estimates of the average thickness of the incoming section during the 42 m.y. history of prism growth, and differences in interpretation of the seismic records [see also Calvert and Clowes, [1990]).
Although the bypassing figures for the large prisms range widely (nil to perhaps $20 \%$ ), we currently suppose that at least $10 \%( \pm 50 \%)$ of the incoming section bypasses these accretionary bodies. We recognize the large uncertainty associated with this estimate, but trace element and isotopic geochemistry of the arc volcanic rocks of the Lesser Antilles are convincing evidence that sediment bypassing occurs at the massive Barbados Prism [White and Dupre, 1986; Bouysee et al., 1990], and, therefore, possibly at other large accretionary bodies as well. Because large prisms constitute only about $20 \%$ of convergent margins, and convergence rates at them are typically slow $(\sim 30 \mathrm{~km} / \mathrm{m} . y . ;$ Table 2$)$, adopting a $10 \%$ bypass rate adds less than $0.03 \mathrm{~km}^{3} / \mathrm{yr}$ to the global volume of subcrustally subducted sediment, a figure that has little effect on the amount of terrestrial material potentially recycled to the mantle.

By applying the corresponding bypass percentages to the long-term rate at which oceanic sediment enters subduction zones (i.e., $100 \%$ of $0.4 \mathrm{~km}^{3} / \mathrm{yr}$ at nonaccreting margins, and, corrected for high Neogene sedimentation, $65 \%$ of $0.4 \mathrm{~km}^{3} / \mathrm{yr}$ at accreting margins with small-tomedium prisms, and $10 \%$ of $0.3 \mathrm{~km}^{3} / \mathrm{yr}$ at large prisms, Table 2), the global rate at which sediment is subcrustally subducted is $0.7 \mathrm{~km}^{3} / \mathrm{yr}$. To this mass must be added the global volume of material provided by subduction erosion, estimated to range from a minimum of 0.6 to as much as $1.1 \mathrm{~km}^{3} / \mathrm{yr}$. In Table 3 we thus show two scenarios for the volume of subcrustally subducted terrestrial material, 1.3 and $1.8 \mathrm{~km}^{3} / \mathrm{yr}$. The mean of this range, $1.6 \mathrm{~km}^{3} / \mathrm{yr}$, is regraded as a conservative estimate of the long-term rate at which terrestrial matter is subcrustally subducted.

Three fates await subcrustally subducted material it can either (1) underplate the base of continental or island-arc crustal rocks, (2) enter the mantle and recycle to the crust via processes of arc magmatism, or (3) be entrained into mantle circulation. Insofar as the net growth of continental crust is concerned, a critical issue is the amount of subducted terrestrial matter that is not returned to the crust but absorbed into the mantle [Karig and Kay, 1981; Armstrong, 1971, 1981; Thorpe et al., 1981; Reymer and Schubert, 1984; Ashwal, 1989; Warren, 1989; Albarede, 1989].

The occurrence in young volcanic rocks of cosmogenically formed ${ }^{10} \mathrm{Be}$ is "smoking gun" evidence that, as Coats [1962] surmised, oceanic sediment travels at least $200 \mathrm{~km}$ landward of the trench and to depths of $100 \mathrm{~km}$ [Brown et al., 1982; Tera et al., 1986; Morris et al., 1990]. Despite this fact, the trace element and isotopic composition of arc magmatic rocks discloses that their mass is overwhelmingly supplied by the melting of mantle rock and only a few percent is contributed by subducted terrestrial material (see, for example, Kay [1980], Gill [1981], and Stern, [1991].

Evidence has also been recognized that some subducted terrestrial material is reattached to continental and island-arc crust by underplating processes. For example, 
seamounts underplated at a depth of $20 \mathrm{~km}$ have been identified in field exposures [Maruyama and Liou, 1989], and acoustic imaging has debatably located underplated masses of oceanic crust and sediment at depths of 15-30 km [Yorath et al., 1985; Yorath, 1987; Green et al., 1986; Clowes et al., 1987; Mooney and Brocher, 1987; Trehu and Wheeler, 1987; Hyndman, 1988; Fisher et al., 1989; Klemperer, 1989; Plafker et al., 1989; Wolf and Levander, 1989]. Relatively large masses of subcrustally underplated material are associated, in particular, with continental collision zones [Le Pichon, 1982; Platt, 1986]. But, to gain a global perspective, consider the consequences of underplating much of the deeply subducted material. At a potential subcrustal transport rate of $1.6 \mathrm{~km}^{3} / \mathrm{yr}$ the flow of terrestrial matter landward of that part of the buttress thinned by basal erosion is approximately $35 \mathrm{~km}^{3} / \mathrm{m}$.y. for each kilometer of trench (presently $-43,500 \mathrm{~km}$ ). At this rate, a new 200-km-wide, 40-km-thick sector of crust of metamorphic rock with a high-pressure formative history would be built in less than $200 \mathrm{~m} . y$. Because surface exposures of these rocks are globally small, seemingly only a relatively small fraction of subcrustally subducted terrestrial matter deeply underplates continental and island-arc crust [Irwin and Coleman, 1972; Ernst, 1988; Peacock, 1990]. Conversely, the lower crustal depth of underplating tends to minimize surface exposures of these rocks.

If much of the terrestrial material is accordingly not returned to the crust as arc igneous or subcrustally underplated metamorphic rock, then a main repository for deeply subducted material must be the mantle. Reymer and Schubert [1984] estimate that during the past 600 m.y. or so the addition of juvenile igneous rocks to the terrestrial crust has averaged about $1.65 \mathrm{~km}^{3} / \mathrm{yr}$. In comparison to the potential rates of subcrustal subduction listed in Table 3 (1.3-1.8 $\left.\mathrm{km}^{3} / \mathrm{yr}\right)$ it can be argued that little net continental growth has occurred during at least the past 100-200 million years. This conclusion comforts models calling for an effective crust mantle exchange of trace element and isotopic material (see, for example, DePaolo [1983, 1988] and Veizer and Jansen [1985], and in particular those requiring litile or no net growth of the terrestrial mass during the latter part of Earth's history as proposed by Armstrong [1981] and Allegre [1982]. Alternatively, during this time the rate of addition of juvenile crust may have been higher than commonly estimated, as considered likely by Albarede [1989] and hinted at by studies of older crustal masses [Reymer and Schubert, 1986].

\section{SUMMING REMARKS}

Geological and geophysical information reviewed in this paper support the notion that about half of ocean floor sediment arriving at convergent ocean margins is subducted and does not contribute to the volumetric growth of an accretionary prism through either frontal or subsurface underplating processes. Also removed to subcrustal depths is material tectonically eroded from the upper plate. Noted below are estimated volumetric rates of the companion processes of sediment subduction and subduction erosion and some considerations of their geologic implications.

1 . We estimate that the total solid-volume mass of ocean floor sediment (ocean basin and trench axis deposits) presently entering the approximately $43,500 \mathrm{~km}$ of convergent margins subduction zones is $1.9 \mathrm{~km}^{3} / \mathrm{yr}$. Of this volume, $0.9 \mathrm{~km}^{3} / \mathrm{yr}(\sim 50 \%)$ is retained and tectonically piled into an accretionary prism by frontal and underplating mechanisms, and $1.0 \mathrm{~km}^{3} / \mathrm{yr}(-50 \%)$ bypasses the entire prism-forming process.

2. Processes of subduction accretion form small-tomedium-sized (5-40 km in width) accretionary prisms at approximately $16,300 \mathrm{~km}$ of accreting or type 1 ocean margins. We estimated that about $20 \%$ of the incoming sediment is offscraped above a detachment or decollement surface to form a frontal accretionary mass, and the remaining $80 \%$ is subducted below and landward of the margin's active buttress, which is the leading edge of structurally consolidated older accretionary material. The total solid-volume mass of sediment subducted at the active buttress is $0.7 \mathrm{~km}^{3} / \mathrm{yr}$.

3. Large accretionary masses border about $8200 \mathrm{~km}$ of accreting margins, at which we infer that 70 percent, or 0.4 $\mathrm{km}^{3} / \mathrm{yr}$, is subducted landward of the active buttress. Thus the total amount of sediment subducted at type 1 margins (both at small and large prism) is at least $1.1 \mathrm{~km}^{3} / \mathrm{yr}$.

4. Over several million years, little net accretion of ocean floor sediment occurs along nonaccreting or type 2 margins, which sum about $19,000 \mathrm{~km}$ in length. At these margins an average solid-volume layer of ocean basin deposits $0.24 \mathrm{~km}$ thick is subducted at the leading edge of the framework of basement-type rocks constructing the landward trench slope. The global sediment subduction rate is thus equal to the incoming rate, which is 0.40 $\mathrm{km}^{3} / \mathrm{yr}$. Combined with sediment subduction at type 1 margins, the contemporary global rate of sediment subduction at the seaward position of the buttress is therefore $1.5 \mathrm{~km}^{3} / \mathrm{yr}$.

5. Because ocean margin tectonism and cycles of continental glaciation have more-or-less steadily increased rates of terrigenous ocean floor sedimentation during the past 30 m.y., the contemporary thickness of the dominantly terrigenous sediment entering the subduction zones of type 1 margins is perhaps twice that typical of the Cenozoic. Applying this correction to the contemporary thickness of incoming sediments to accretionary prisms, the long-term rate of sediment subduction at type 1 margins falls from 1.1 to $0.55 \mathrm{~km}^{3} / \mathrm{yr}$. The long-term rate of global sediment subduction at all margins is thus estimated to be 1.0 $\mathrm{km}^{3} / \mathrm{yr}$.

6. Of particular interest is the long-term rate at which incoming sediment is deeply subducted and does not contribute to the volumetric growth of an accretionary prism. Mass balance calculations allow us to estimate that 
$100 \%$ of the incoming section is subcrustally subducted at type 2 margins, $65 \%$ at type 1 margins with small to medium prisms, and possibly as little as $10 \%$ where large prisms have formed. The corresponding long-term rate of bypass or subcrustally subducted ocean sediment is 0.7 $\mathrm{km}^{3} / \mathrm{yr}$.

7. Much of the bypass sediment subducted at type 1 margins is silty and sandy clastic deposits of terrigenous origin, and bypass sediment subducted at type 2 margins is predominantly fine grained and clayey pelagic and hemipelagic sediment. Therefore about $40 \%$ pelagic and $60 \%$ clastic deposits are subcrustally subducted at modern convergent margins, but the long-term proportions are, respectively, 56 and $44 \%$.

8. The pore-fluid volume squeezed from frontally accreted sediment and returned to the oceans is estimated at $0.1 \mathrm{~km}^{3} / \mathrm{yr}$. Pore fluids squeezed from subducted sediment, whether underplated or subcrustally subducted, amount to $0.8 \mathrm{~km}^{3} / \mathrm{yr}$ for a total return flux to the ocean basins of $-0.9 \mathrm{~km}^{3} / \mathrm{yr}$.

9. Subduction erosion removes and subducts material from the upper plate, in particular, the rock framework landward of the core buttress. Estimates of long-term rates of erosion have only been well constrained off northern Japan and central Peru. These rates are, respectively, 50 and $25 \mathrm{~km}^{3} / \mathrm{m}$.y. for each kilometer of margin. A long-term rate of erosion of $30 \mathrm{~km}^{3} / \mathrm{m} . \mathrm{y} . / \mathrm{km}$, which is considered applicable to many margins, is estimated from these values. Although processes of subduction erosion may remove older parts of actively growing accretionary wedges, these volume losses are included in estimates of the subducted sediment that bypasses the accretionary prism.

10. If the long-term rate of subduction erosion is applied to the length of type 2 or nonaccretionary margins, then the global rate of upper plate erosion is $0.6 \mathrm{~km}^{3} / \mathrm{yr}$. If the length of type 1 margins fronted by small-to-medium-sized accretionary prisms, for example, Peru and Japan, is factored in, then the global rate could increase by as much as $0.5 \mathrm{~km}^{3} / \mathrm{yr}$ for a yearly total of $1.1 \mathrm{~km}^{3} / \mathrm{yr}$. Subduction erosion of the rock framework backing margins with large prisms cannot be estimated.

11. Subducted sediment and eroded upper plate material is dominantly composed of terrestrial matter (continental and island arc material). Thus by combining the long-term rate of subcrustally subducted sediment $\left(0.7 \mathrm{~km}^{3} / \mathrm{yr}\right)$ with the most likely range of material removed by subduction erosion, the estimated rate of subcrustally subducted terrestrial matter is $1.6 \mathrm{~km}^{3} / \mathrm{yr}$ (range of 1.3 to $1.8 \mathrm{~km}^{3} / \mathrm{yr}$, Table 3).

12. During the latter part of Earth's history, the commonly accepted addition rate of juvenile igneous rock to the store of terrestrial crust is $1.65 \mathrm{~km}^{3} / \mathrm{yr}$. If subcrustally subducted material is substantially recycled to the mantle, which seems likely, then the global volume of terrestrial crust may not have greatly changed during the past several hundred million years.
ACKNOWLEDGMENTS. The authors wish to thank additional readers of the original manuscript who provided welcomed guidance concerning the scientific content and relevance of its message were David Howell and Steven Lewis.

M. Neugebauer was the editor responsible for this paper. She thanks Mark Cloos and Robert Kay for their assistance in evaluating its technical content and an anonymous referee for assistance in evaluation of its readability across disciplines.

\section{REFERENCES}

Albarede, F., Sm/Nd constraints on the growth rate of continental crust, Tectonophysics, 161, 299-305, 1989.

Allegre, C. J., Chemical geodynamics, Tectonophysics, 81, 109-132, 1982.

Andriessen, P. A. M., and K. J. Reutter, K-Ar and fission track mineral age determinations of igneous rocks related to multiple magmatic arc systems along the $23^{\circ} \mathrm{S}$ latitude of Chile and NW Argentina, in Tectonics of the Southern Central Andes, edited by K. J. Reutter, E. Scheubes, and P. J. Wigges, Springer-Verlag, New York, in press, 1991.

Aoki, Y., T. Tamano, and S. Kato, Detailed structure of the Nankai Trough from migrated seismic sections, Studies in Continental Margin Geology, edited by J. S. Watkins and C. L. Drake, AAPG Mem., 30, 309-322, 1982.

Armstrong, R. L., Isotopic and chemical constraints on models of magma genesis in volcanic arcs, Earth Planet. Sci. Lett., 12, 137-142, 1971.

Armstrong, R. L., Radiogenic isotopes: The case for crustal recycling on a near-steady-state no continental-growth Earth, Philos. Trans. R. Soc. London, Ser. A, 301, 443-472, 1981.

Amdt, N. T., and S. L. Goldstein, An open boundary between lower continental crust and mantle: Its role in crust formation and crustal recycling, Tectonophysics, 161, 201-212, 1989.

Ashwal, L. D., Introduction, Tectonophysics, 161, 143-145, 1989.

Atwater, T., Plate tectonic history of the northeast Pacific and western North America, in The Eastern Pacific Ocean and Hawaii, The Geology of North America, N, edited by E. L. Winterer, D. M. Hussong, and R. W. Decker, pp. 21-72, Geological Society of America, Boulder, Colo., 1989.

Aubouin, J., and R. von Huene, Summary: Leg 84, Middle America Trench transect off Guatemala and Costa Rica, Initial Rep. Deep Sea Drill. Proj., 84, 939-957, 1985.

Ballance, P. F., D. W. Scholl, T. L. Vallier, A. J. Stevenson, H. Ryan, and R. H. Herzer, Subduction of a Late Cretaceous seamount of the Louisville Ridge at the Tonga Trench: A model of normal and accelerated tectonic erosion, Tectonics, 8, 95-962, 1989.

Ballesteros, M. W., G. F. Moore, B. Taylor, and S. Ruppert, Seismic stratigraphic framework of the Lima and Yaquina forearc basins, Peru, Deep Sea Drilling Project, Proc. Ocean Drill. Prog. Initial Rep., 112, 77-90, 1988.

Bally, A. W., Seismic expression of structural styles, AAPG Stud. Geol. 3, 1983.

Bangs, N., S. C. Cande, S. D. Lewis, and S. Tebbens, Seismic evidence for tectonic erosion at the Chile margin-Chile ridge collision zone (abstract), Eos Trans. AGU, 70, 1314, 1989.

Beaudry, D., and G. F. Moore, Seismic stratigraphy and Cenozoic evolution of west Sumatra forearc basin, $A A P G$ Bull., 69, 742-759, 1985.

Beck, M. E., Jr., On the mechanism of tectonic transport in zones of oblique subduction, Tectonophysics, 93, 1-11, 1983.

Beck, M. E., Jr., Model for late Mesozoic-early Tertiary tectonics of coastal Califomia and western Mexico and speculations on the origin of the San Andreas fault, Tectonics, 5, 49-64, 1986. 
Bickford, M. E., The formation of continental crust: Part 1. A review of some principles, Part 2, An application to the Proterozoic evolution of southern North America, Geol. Soc. Am. Bull., 100, 1375-1391, 1988.

Biju-Duval, B., P. Le Quellec, A. Mascle, V. Renard, and P. Valery, Multibeam bathymetric survey and high resolution seismic investigations on the Barbados ridge complex (eastem Caribbean): A key to the knowledge and interpretation of an accretionary wedge, Tectonophysics, 86, 275-304, 1982.

Bloomer, S. H., Distribution and origin of igneous rocks from the landward slopes of the Marian Trench: Implications for its structure and evolution, J. Geophys. Res., 88, 7411-7428, 1983.

Bloomer, S. H., and R. L. Fisher, Petrology and geochemistry of igneous rocks from the Tonga Trench-A non-accreting plate boundary, J. Geol., 95, 469-495, 1987.

Bloomer, S. H., and R. L. Fisher, Arc volcanic rocks characterize the landward slope of the Philippine trench off northwestem Mindanao, J. Geophys. Res., 93, 11,961-11,973, 1988.

Borja, R. I., and S. J. Dreiss, Numerical modeling of accretionary wedge mechanics: Application to the Barbados subduction problem, J. Geophys. Res., 94, 9323-9339, 1989.

Bouysse, P. D., D. Westercamp, and P. Andreieft, The Lesser Antilles Island arc, Proc. Ocean Drill. Prog. Sci. Results, 110, 29-43, 1990.

Bray, C. J., and D. E. Karig, Porosity of sediments in accretionary prisms, and some implications for dewatering processes, $J$. Geophys. Res., 90, 768-778, 1985.

Breen, N. A., E. A. Silver, and D. M. Hussong, Structural styles of an accretionary wedge south of the island of Sumba, Indonesia, revelaed by Sea MARCII side scan sonar, Geol. Soc. Am. Bull, 97, 1250-1261, 1986.

Breen, N. A., J. E. Tagudin, D. L. Reed, and E. A. Silver, Mud-cored parallel folds and possible melange development in the north Panama thrust belt, Geology, 16, 207-210, 1988.

Brown, K., and G. K. Westbrook, Mud diapirism and subcretion in the Barbados Ridge accretionary complex: The role of fluids in accretionary processes, Tectonics, 7, 613-640, 1988.

Brown, K. M., A. Mascle, and J. H. Behrmann, Mechanisms of accretion and subsequent thickening in the Barbados Ridge accretionary complex: Balance cross sections across the wedge toe, Proc. Ocean Drill. Prog. Sci Results, 110, 209-227, 1990.

Brown, L., J. Klein, R. Middleton, I. S. Sacks, and F. Tera, ${ }^{10} \mathrm{Be}$ in island-arc volcanoes and implications for subduction, Nature, 299, 718-720, 1982.

Calvert, A. J., and R. M. Clowes, Deep, high-amplitude reflections from a major shear zone above the subducting Juan de Fuca plate, Geology, 18, 1091-1094, 1990.

Cande, S. C., and R. B. Leslie, Late Cenozoic tectonics of the southem Chile Trench, J. Geophys. Res., 91, 471-496, 1986.

Cande, S. C., S. D. Lewis, N. Bangs, S. Tebbens, and R. Forman, Interaction of the Chile ridge and Chile trench: Preliminary results from a SEABEAM and MCS survey (abstract) Eos Trans. $A G U, 69,1407,1988$.

Carson, B., R. von Huene, and M. Arthur, Small-scale deformation structures and physical properties related to convergence in Japan trench slope sediments, Tectonics, 1, 277-302, 1982.

Charlton, T. R., Tectonic erosion and accretion in steady-state trenches, Tectonophysics, 149, 233-23, 1988.

Chase, R. L., and E. T. Bunce, Underthrusting of the eastern margin of the Antilles by the floor of the western North Atlantic Ocean, and origin of the Barbados ridge, J. Geophys. Res., 74, 11,413, 1969.

Cloos, M., and R. L. Shreve, Subduction-channel model of prism accretion, melange formation, sediment subduction, and subduction erosion at convergent plate margins, 1, Background and description, Pure Appl. Geophys., 128, 456-500, $1988 a$.
Cloos, M., and R. L. Shreve, Subduction-channel model of prism accretion, melange formation, sediment subduction, and subduction erosion at convergent plate margins, 2, Implications and discussion, Pure Appl. Geophys., 128, 501-505. $1988 b$.

Clowes, R. M., M. T. Brandon, A. G. Green, C. L. Yorath, A. S. Brown, E. R. Kanasewich, and C. Spencer, LITHOPROBE-Southem Vancouver Island: Cenozoic subduction complex imaged by deep seismic reflections, Can J. Earth Sci., 24, 31-51, 1987.

Coats, R. R., Magma type and crustal structure in the Aleutian Arc, in Crust of the Pacific Basin, Geophys. Monogr. Ser., vol. 6, edited by G. A. McDonald and H. Kuno, pp. 92-109, AGU, Washington, D. C., 1962.

Collot, J. Y., and M. A. Fisher, Formation of forearc basins by collision between seamounts and accretionary wedges: An example from New Hebrides subduction zone, Geology, 17, 930-933, 1989.

Coney, P. J., D. L. Jones, and J. W. H. Monger, Cordilleran suspect terranes, Nature, 239, 329-333, 1980.

Copeland, P., and T. M. Harrison, Episodic rapid uplift in the Himalaya revealed by ${ }^{40} \mathrm{Ar}{ }^{39} / \mathrm{Ar}$ analysis of detrital $\mathrm{K}$-feldspar and muscovite, Bengal fan, Geology, 18, 354-357, 1990.

Curray, J. R., and D. G. Moore, Growth of the Bengal deep-sea fan and denudation in the Himalayas, Geol. Soc. Am. Bull., 82, 563-572, 1971.

Davies, T. A., W. W. Hay, J. R. Southam, and T. R. Worsely, Estimates of Cenozoic ocean sedimentation rates, Science, 197, 53-55, 1977.

Davis, D., J. Suppe, and F. A. Dahlen, Mechanics of fold- and thrust-belts and accretionary wedges, J. Geophys. Res., 88, 1153-1172, 1983.

Davis, D. M., and R. von Huene, Inferences on sediment strength and fault friction from structures at the Aleutian Trench, Geology, 15, 517-522, 1987.

Davis, E. E., and R. D. Hyndman, Accretion and recent deformation of sediment along the northern Cascadia subduction zone, Geol. Soc. Am. Bull., 101, 1465-1480, 1989.

DePaolo, D. J., The mean life of continents: Estimates of continent recycling rates from Nd and Hf isotopic data and implications for mantle structure, Geophys. Res. Lett., 10, 705-708, 1983.

DePaolo, D. J., Neodymium Isotope Geochemistry-An Introduction, 187 pp., Springer-Verlag, New York, 1988.

Dewey, J. F., and B. F. Windley, Growth and differentiation of the continental crust, Philos. Trans. R. Soc. London, Ser. A, 301, 189-206, 1981.

Dickinson, W. R., Provenance and sediment dispersal in relation to paleotectonics and paleogeography of sedimentary basins, in Frontiers in Sedimentary Geology, edited by K. L. Kleinspehn and C. Paolo, pp. 3-24, Springer-Verlag, New York, 1988.

Engebretson, D. C., A. Cox, and R. G. Gordon, Relative motions between oceanic and continental plates in the Pacific Basin, Geol. Soc. Am. Spec. Pap., 206, 59 pp., 1985.

Emst, W. G., Tectonic contact between the Franciscan melange and the Great Valley Sequence-Crustal expression of a late Mesozoic Benioff zone, J. Geophys. Res., 75, 886-901, 1970.

Emst, W. G., Metamorphic terranes, isotopic provinces, and implications for crustal growth of the western United States, $J$. Geophys. Res., 93, 7634-7642, 1988.

Fisher, M. A., T. M. Brocher, W. J. Nokleberg, G. Plafker, and G. L. Smith, Seismic reflection images of the crust of the northern part of the Chugach terrane, Alaska: Results of a survey for the Trans-Alaska Crustal Transect (TACT), $J$. Geophys. Res., 94, 4424-4440, 1989.

Fisher, R. L., On the sounding of trenches, Deep Sea Res., 2, 48-58, 1954. 
Fryer, P., and D. M. Hussong, SEAMARC II studies of subducting seamounts, in Formation of Active Ocean Margins, edited by N. Nasu et al., pp. 291-306, Terra Scientific, Tokyo, 1985.

Fryer, P., and N. C. Smoot, Processes of seamount subduction in the Mariana and Izu-Bonin trenches, Marine Geol., 64, 77-90, 1985.

Fujioka, K., Geology of volcanogenic sediments of the Japan area and Tertiary explosive volcanism of the NE Japan area, Bull. Ocean Res. Inst., Univ. Tokyo, 18, 276 pp., 1985.

Gill, J. B., Orogenic Andesites and Plate Tectonics, 390 pp., Springer-Verlag, 1981.

Gilluly, J., Tectonic evolution of the westem United States, Geol. Soc. London Quat. J., 119, 133-174, 1963.

Gnibidenko, G. S., T. G. Bykova, O. V. Veselov, V. M. Vorob'yev, U. C. Kim, and T.Z. Tarakanov, Tectonics of the Kurile-Kamchatka Deep-Sea Trench, Moscow (in Russian), Nauka Publishing, 179 pp., 1980.

Gordon, G. G., and D. M. Jurdy, Cenozoic global plate motions, J. Geophys. Res., 91, 12,389-12,406, 1986.

Green, A. G., R. M. Clowes, C. J. Yorath, C. Spencer, E. R. Kanasewich, M. T. Brandon, and A. Sutherland Brown, Seismic reflection imaging of the subducting Juan de Fuca plate, Nature, 319, 210-213, 1986.

Grow, J. A., and T. Atwater, Mid-Tertiary tectonic transition in the Aleutian Arc, Geol. Soc. Am. Bull., 81, 3715-3722, 1970.

Hamilton, E. L., Variations of density and porosity with depth in deep-sea sediments, J. Sediment. Petrol., 46, 280-300, 1976.

Hamilton, E. L., Sound velocity-density relations in sea-floor sediments and rocks, J. Acoust. Soc. Am., 63, 366-377, 1978.

Hamilton, W. B., Mesozoic California and the underflow of the mantle, Geol. Soc. Am. Bull., 80, 2409-2430, 1969.

Hamilton, W. B., Plate tectonics and island arcs, Geol. Soc. Am. Bull., 100, 1503-1527, 1988.

Hay, W. W., J. L. Sloan II, and C. N. Wold, Mass/age distribution and composition of sediments on the ocean floor and the global rate of sediment subduction, J. Geophys. Res., 93, 14,933-14,940, 1988.

Hayes, D. E., and S. D. Lewis, A geophysical study of the Manila trench, Luzon, Philippines, 1, Crustal structure, gravity, and regional tectonic evolution, J. Geophys. Res., 89, 9171-9195, 1984.

Hayes, D. E., and S. D. Lewis, Structure and tectonics of the Manila trench system, Westem Luzon, Philippines, Energy, 10, 263-279, 1985.

Helwig, J., Eugeosynclinal basement and a collage concept of orogenic belts, in Modern and Ancient Geosynclinal Sedimentation, Soc. Econ. Paleontol., Min. Spec. Publ., vol. 19, edited by R. H. Dott and R. H. Shaver, pp. 359-376, Society of Economic Paleontologists and Mineralogists, Tulsa, Okla., 1974.

Helwig, J., and G. A. Hall, Steady-state trenches?, Geology, 2, 309-316, 1974.

Hilde, T. W. C., Sediment subduction vs accretion around the Pacific, Tectonophysics, 99, 381-397, 1983.

Hilde, T. W. C., and G. F. Sharman, Fault structure of the descending plate and its influence on the subduction process (abstract), Eos Trans. AGU, 59, 1182, 1978.

Hilde, T. W. C., and S. Uyeda, Trench depth variation and significance, in Geodynamics of Western Pacific-Indonesian Region, Geodyn. Ser., vol. 11, edited by T. W. C. Hilde, and S. Uyeda, pp. 75-89, AGU, Washington, D. C., 1982.

Hilde, T. W. C., J. M. Wageman, and W. T. Hammond, The structure of Tosa Terrace and Nankai Trough off southwestern Japan, Deep Sea Res., 16, 67-75, 1969.

Honza, E., and K. Tamaki, The Bonin Arc, in The Ocean Basins and Margins, vol. 7A, The Pacific Ocean, edited by A. E. M. Nairn, F. G. Stehli, and S. Uyeda, pp. 459-502, Plenum, New York, 1985.
Hottman, C. E., J. F. Smith, and W. P. Purcell, Relationship among earth stresses, pore pressure and drilling problems, offshore Gulf of Alaska, J. Pet. Technol., 31, 1477-1484, 1979.

Howell, D. G., Tectonics of Suspect Terranes, Mountain Building and Continental Growth, 232 pp., Chapman and Hall, London, 1989a.

Howell, D. G., How the growth and freeboard of continents may relate to geometric and kinematic parameters of mid-ocean spreading ridges, Tectonophysics, 161, 343-349, 1989 b.

Howell, D. G., and R. W. Murray, A budget for continental growth and denudation, Science, 233, 446-449, 1986.

Hubbert, M. K., and W. W. Rubey, Role of fluid pressure in mechanics of overthrust faulting, Geol. Soc. Am. Bull., 70, 115-206, 1959.

Hussong, D. M., and P. Fryer, Fore-arc tectonics in the northem mariana arc, in Formation of Active Ocean Margins, edited by N. Nasu et al., pp. 273-290, Terra Scientific, Tokyo, 1985.

Hussong, D. M., and S. Uyeda, Tectonic processes and the history of the Mariana Arc: A synthesis of the results of Deep Sea Drilling Project, leg 60, Initial Rep. Deep Sea Drill. Proj., 60, 909-929, 1982.

Hussong, D. M., and L. K. Wipperman, Vertical movement and tectonic erosion of the continental wall of the Peru-Chile trench near $11^{\circ} 30^{\prime} \mathrm{S}$ latitude, in Nazca Plate: Crustal Formation and Andean Convergence, edited by L. D. Kulm, J. Dymond, E. J. Dasch, and D. M. Hussong, Mem. Geo. Soc. Am., 154, pp. 509-524, 1981.

Hussong, D. M., P. B. Edwards, S. H. Johnson, J. F. Campbell, and G. H. Sutton, Crustal structure of the Peru-Chile trench: $8^{\circ}-12^{\circ} \mathrm{S}$ latitude, in The Geophysics of the Pacific Ocean Basin and its Margin, Geophys. Monogr. Ser., vol. 19, edited by G. H. Sutton, M. H. Manghani, and R. Moberly, pp. 71-85, AGU, Washington, D. C., 1976.

Hyndman, R. D., Dipping seismic reflectors, electrically conductive zones, and trapped water in the coast over a subducting plate, J. Geophys. Res., 93, 13,391-13,405, 1988.

Irwin, W. P., and R. G. Coleman, Preliminary map showing global distribution of alpine-type ultramafic rocks and blieschists, U.S. Geol. Surv. Misc. Field Stud. Map. MF, 340, 1972.

Jarrard, R. D., Relations among subduction parameters, Rev. Geophys., 24, 217-284, 1986a.

Jarrard, R. D., Terrane motion by strike-slip faulting of forearc slivers, Geology, 14, 780-783, $1986 b$.

Jayko, A. S., M. C. Blake, Jr., and T. Harms, Attenuation of the coast range ophiolite by extensional faulting, and nature of the coast range "Thrust," California, Tectonics, 6, 475-488, 1987.

Jones, G. M., T. W. C. Hilde, G. F. Sharman, and D. C. Agnew, Fault patterns in outer trench walls and their tectonic significance, J. Phys. Earth, 26, 85-101, 1978.

Karig, D. E., and G. F. Sharman III, Subduction and accretion in trenches, Earth Planet Sci. Lett., 86, 377-389, 1975.

Karig, D. E., Tectonic erosion at trenches, Earth Planet. Sci. Lett., 21, 209-212, 1974.

Karig, D. E., and R. W. Kay, Fate of sediments on the descending plate at convergent margins, Philos. Trans. R. Soc. London, Ser. A, 301, 233-251, 1981.

Karig, D. E., and B. Ranken, Marine geology of the forearc region, southem Mariana Island arc, in The Tectonic and Geologic Evolution of Southeast Asian Seas and Islands, Geophys. Monogr. Ser., vol. 27, edited by D. E. Hayes, pp. 266-280, AGU, Washington, D. C., 1983.

Karig, D. E., J. G. Caldwell, and E. M. Parmentier, Effects of accretion on the geometry of the descending lithosphere, $J$. Geophys. Res., 81, 6281-6291, 1976.

Kay, R. W., Volcanic arc magmas: Implications of a meltingmixing model for element recycling in the crust-upper mantle system, J. Geol., 88, 497-522, 1980. 
Klemperer, S. L., Deep seismic reflection profiling and the growth of the continental crust, Tectonophysics, 161, 233-244, 1989.

Kobayashi, K., Preliminary report of the Hakuho Maru cruise KH 84-1, April 16-May 30, 1984, Geological and geophysical investigation of seafloor east of Ogasawara (Bonin) islands, northem Mariana trough, southem Mariana, Yap and Palau trench and arcs, Ocean Res. Inst., Univ. Tokyo, 305 pp., 1985.

Kobayashi, K., et al., Normal faulting of Daiichi Kashima seamount in the Japan trench revealed by the Kaiko 1 cruise, leg 3, Earth Planet. Sci. Lett., 83, 257-266, 1987.

Kulm, L. D., et al., Initial Reports of the Deep Sea Drilling Projects, vol. 18, 1077 pp., Washington, D. C., 1973.

Kulm, L. D., T. M. Thomburg, E. Suess, J. Resig, and P. Fryer, Clastic diagentic, and metamorphic lithologies of a subsiding continental block: Central Peru forearc, Proc. Ocean Drill. Prog. Initial Rep., 112, 91-107, 1988.

Ladd, J. W., G. K. Westbrook, P. Buhl, and N. Bangs, Wideaperture seismic reflection profiles across the Barbados Ridge complex, Proc. Ocean Drill. Prog. Sci. Results, 110 3-6, 1990.

Lallemand, S., and N. Chamot-Rooke, Sur la cause du décrochement senestre entre les fosses du Japon et des Kouriles: Subduction-collision d'un ancien volcan sous-marin, $C$. $R$. Acad. Sci. Paris, Ser. 2, 303, 1443-1448, 1986.

Lallemand, S., and X. Le Pinchon, Coulomb wedge model applied to subduction of seamounts in the Japan Trench, Geology, 15, 1065-1069, 1987.

Lallemand, S., R. Culotta, and R. von Huene, Subduction of the Daiichi Kashima seamount in the Japan Trench, Tectonophysics, 160, 231-247, 1989.

Langseth, M. G., and J. C. Moore, Introduction to special section on the role of fluids in sediment accretion, deformation, diagenesis, and metamoprhism in subduction zones, $J$. Geophys. Res., 95, 8737-8741, 1990.

Langseth, M. G., R. von Huene, N. Nasu, and H. Okada, Subsidence of the Japan Trench forearc region off northern Honshu, Oceanol. Acta, 4, supplement, 173-179, 1981.

Le Pichon, X., Land-locked oceanic basins and continental collision: The eastem Mediterranean as a case example, in Mountain Building Processes, edited by K. J. Hsu, pp. 201-211, Academic, Troy, Mo., 1982.

Le Pichon, X., J. P. Foucher, J. Boulègue, P. Henry, S. Lallemant, M. Benedetti, F. Avedik, and A. Mariotti, Mud volcano field seaward of the Barbados accretionary complex: A submersible survey, J. Geophys. Res., 95, 8931-8943, 1990.

Lewis, S. D., and D. E. Hayes, A geophysical study of the Manilla Trench, Luzon, Philippines, 2, Fore-arc basin structural and stratigraphic evolution, J. Geophys. Res., 89, 9196-9214, 1984.

Lister, G. S., B. Greetje, and A. Feenstra, Metamorphic core complexes of cordilleran type in the Cyclades, Aegean Sea, Greece, Geology, 12, 221-225, 1984.

Lonsdale, P. F., A multibeam reconnaissance of the Tonga Trench axis and its intersection with the Louisville guyot chain, Mar. Geophys. Res., 8, 295-327, 1986.

Lonsdale, P. F., Paleogene history of the Kula plate: Offshore evidence and onshore implications, Geol. Soc. Am. Bull., 93, 13551-13574, 1988.

MacKay, M., G. Cochrane, G. F. Moore, J. C. Moore, and L. D. Kulm, High resolution seismic study of the Oregon accretionary prism (abstract) Eos Trans. AGU, 70, 1345, 1989.

Maruyama, S., and J. G. Liou, Possible depth limit for underplating by a seamount, Tectnophysics, 160, 327-337, 1989.

Mascle, A., and J. C. Moore, ODP leg 110: Tectonic and hydrologic synthesis, Proc. Ocean Drill. Prog. Sci. Results, 110, 409-425, 1990.
McCarthy, J., and D. W. Scholl, Mechanism of subduction accretion along the central Aleutian Trench, Geol. Soc. Am. Bull., 96, 691-701, 1985.

McKee, E. H., and D. C. Noble, Cenozoic tectonic events, magmatic pulses, and base- and precious-metal mineralization in the central Andes, in Geology of the Andes and Its Relation to Hydrocarbon and Mineral Resources, Earth Sci. Ser., vol. 11, edited by G. E. Ericksen, M.-T. C. Pinochet, and J. A. Reinemund, pp. 189-194, in Circum-Pacific Council for Energy and Mineral Resources, Houston, Tex., 1990.

Meade, R. H., Movement and storage of sediment in river systems, in Physical and Chemical Weathering in Geochemical Cycles, edited by A. Lerman and M. Meybeck, pp. 165-179, Kluwer, Dordrecht, Holland, 1988.

Meade, R. H., River-sediment inputs to major deltas, in Sea-Level Rise and Coastal Subsidence, Problems and Strategies, edited by J. D. Milliman and S. Sabhasri, Wiley, Scope Series, in press, 1991.

Miller, H., Das Problem des hypothetischen "Pazifischen Kontinentes" gesehen von der chilenischen Pazifikkuste, Geol. Rundsch., 59, 927-938, 1970a.

Miller, H., Vergleichende Studies an pramesozoischen Gesteinen Chiles unter besonderer Berucksichtigung ihrer Kleintektonik, Geotek. Forsch., 36, 1-64, $1970 b$.

Milliman, J. D., and R. H. Meade, World-wide delivery of river sediment to the oceans, J. Geology, 91, 1-21, 1983.

Minshull, T., and R. White, Sediment compaction and fluid migration in the Makran accretionary prism, J. Geophys. Res., 94, 7387-7402, 1989.

Minster, J. B., and T. H. Jordan, Present-day plate motions, $J$ Geophys. Res., 83, 5331-5354, 1978.

Mogi, A., and K. Nishizawa, Breakdown of a seamount on the slope of the Japan trench, Proc. Jpn. Acad. Sci., 56, 257-259, 1980.

Mooney, W. D., and T. M. Brocher, Coincident seismic reflection/refraction studies of the continental lithosphere: A global review, Rev. Geophys., 25, 723-742, 1987.

Moore, G. F., and T. H. Shipley, Mechanisms of sediment accretion in the Middle America Trench off Mexico, $J$. Geophys. Res., 93, 8911-8927, 1988.

Moore, G. F., P. Lonsdale, and R. von Huene, Near-bottom observations of the Middle America Trench off Guatemala Initial Rep. Deep Sea Drill. Proj., 67, 707-718. 1982.

Moore, G. F., T. H. Shipley, and P. F. Lonsdale, Subduction erosion versus sediment offscraping at the toe of the middle America trench off Guatemala, Tectonics, 5, 513-523, 1986.

Moore, G. F., J. R. Curray, D. G. Moore, and D. E. Karig, Variations in geologic structure along the Sunda fore arc, northeastern Indian Ocean, in The Tectonic and Geologic Evolution of Southeast Asian Seas and Islands, Geophys. Monogr. Ser., vol. 23, edited by D. E. Hayes, pp. 145-160, AGU, Washington, D. C., 1980.

Moore, G. F., T. H. Shipley, P. L. Stoffa, D. E. Karig, A. Taira, S. Kuramoto, H. Tokuyama, and K. Suyehiro, Structure of the Nakai trough accretionary zone from multichannel seismic reflection data, J. Geophys. Res., 95, 8743-8752, 1990.

Moore, J. C., and B. Biju-Duval, Tectonic synthesis, Deep Sea Drilling Project leg 78A: Structural evolution of offscraped and underthrust sediment, Northem Barbados Ridge Complex, Initial Rep. Deep Sea Drill. Proj., 78A, 601-621, 1983.

Moore, J. C., J. S. Watkins, and T. S. Shipley, Summary of accretionary processes, DSDP leg 66: Offscraping, underplating, and deformation of the slope apron, Initial Rep. Deep Sea Drill. Proj., 66, 825-836, 1982.

Moore, J. C., T. Byrne, P. W. Plumley, M. Reid, H. Gibbons, and R. S. Coe, Paleogene evolution of the Kodiak Islands, Alaska: Consequences of ridge-trench interaction in a more southerly latitude, Tectonics, 2, 265-293, 1983. 
Moore, J. C., et al., Tectonics and hydrogeology of the northem Barbados Ridge. Results from Ocean Drilling Program leg 110, Geol. Soc. Am. Bull., 100, 1578-1593, 1988.

Moore, J. C., et al., Proceedings of the Ocean Drilling Program: Scientific Results, vol. 110, 445 pp., College Station, Tex., 1990.

Morris, J. D., W. P. Leeman, and F. Tera, The subducted component in island arc lavas: constraints from $\mathrm{Be}$ isotopes and B-Be systematics, Nature, 344, 31-36, 1990.

Morris, J. D., F. Tera, W. P. Leeman, and R. S. Harmon, Beryllium-Boron systematics in island arc lavas: constraints on sediment mixing, Eos Trans. Amer. Geophys. Union, 69, 1509, 1988.

Mpodozis, G., and V. Ramos, The Andes of Chile and Argentina, in Geology of the Andes and Its Relation to Hydrocarbon and Mineral Resources, Earth Sci. Ser., vol. 11, edited by G. E. Ericksen, M.-T. C. Pinochet, and J. A. Reinemund, pp. 59-90, Circum-Pacific Council for Energy and Mineral Resources, Houston, Tex., 1990.

Murauchi, J., The renewal of island arcs and the tectonics of marginal seas, The Ocean World, edited by M. Uda, Proc. Joint Oceanogr. Assembly, Tokyo, 303-305, 1971.

Murauchi, S., and W. J. Ludwig, Crustal structure of the Japan Trench: The effect of subduction of ocean crust, Initial Rep. Deep Sea Drill Proj., 56157, 463-470, 1980.

Naranjo, J. A., A. Puig, and M. Suárez, A note on Lower Jurassic magmatism in the coastal Cordillera of Atacama, Chile, Geol. Mag., 123, 699-702, 1986.

Nasu, N., R. von Huene, Y. Ishiwada, M. Langseth, T. Bruns, and E. Honza, Interpretation of multichannel seismic reflection data, legs 56 and 57, Japan Trench transect, Deep Sea Drilling Project, Initial Rep. Deep Sea Drill. Proj., 56/57, 408-504, 1980.

Oshima, S., T. Ogino, T. Katsura, K. Ikeda, M. Uchida, M. Nagano, M. Hayashida, K. Muneda, S. Kasuga, and S. Tani, Subduction of Daiiti-Kasima seamount into the landward slope of the Japan trench, (in Japanese with English abstract), Rep. Hydrogr. Res., 20, 25-46, 1985.

Peacock, S. M., Fluid processes in subduction zones, Science, 248, 329-337, 1990.

Pelletier, B., Tectonic erosion and consequent retreats of trench and active volcanic arc due to Louisville Ridge subduction in Tonga-Kermadec Trench, Int. Geol. Congr. Abstr., Washington, D. C., 2-591, 1989.

Pelletier, B., and R. Louat, Seismotectonics and present-day relative plate motions in the Tonga-Lau and Kermadec-Havre region, Tectonophysics, 165, 237-250, 1989.

Pelletier, B., and J. Dupont, Effects de la subduction de la ridge de Louisville sur l'arc des Tonga-Kermadec, Oceanol. Acta, 10, 57-76, 1990.

Plafker, G., W. J. Nokleberg and J. S. Lull, Bedrock geology and tectonic evolution of the Wrangellia, Peninsular, and Chugach terranes along the Trans-Alaska crustal transect in the Chugach Mountains and southem Copper River Basin, Alaska, J. Geophys. Res., 94, 4255-4295, 1989.

Platt, J. P., Dynamics of orogenic wedges and the uplift of high-pressure metamorphic rocks, Geol. Soc. Am. Bull., 97, 1037-1057, 1986.

Platt, J. P., The mechanics of frontal imbrication: A first-order analysis, Geol. Rundsch., 77, 577-589, 1989.

Platt, J. P., et al., Large-scale sediment underplating in the Makran accretionary prism, southwest Pakistan, Geology, 13, 507-511, 1985.

Pontoise, B., et al., Océanographie dynamique, C. R. Acad. Sci. Paris, Ser. 2, 303, 911-918, 1986.

Reed, D. L., et al., Relations between mud volcanoes, thrust deformation, slope sedimentation, and gas hydrate, offshore north Panama, Mar. Petrol. Geol., 7, 44-54, 1990.
Reymer, A., and G. Schubert, Phanerozoic addition rates to the continental crust and crustal growth, Tectonics, 3, 63-77, 1984.

Reymer, A., and G. Schubert, Rapid growth of some major segments of continental crust, Geology, 14, 299-302, 1986.

Rogers, G., and C. J. Hawkesworth, A geochemical traverse actoss the north Chilean Andes: Evidence for crust generation from the mantle wedge, Earth Planet. Sci. Lett., 91, 271-285, 1989.

Rutland, R. W. R., Andean orogeny and ocean floor spreading, Nature, 233, 252-255, 1971.

Ryan, H. F., and D. W. Scholl, The evolution of forearc structures along an oblique convergent margin, central Aleutian arc, Tectonics, 8, 497-516, 1989.

Sager, W. W., D. W. Handschumacher, T. W. Hilde, and D. R. Bracey, Tectonic evolution of the northem Pacific plate and Pacific-Farallon-Izanagi triple junction in the Late Jurassic and Early Cretaceous (M21-M10), Tectonophysics, 155, 354-356, 1988.

Sample, J. C., and D. M. Fisher, Duplex accretion and underplating in an ancient accretionary complex, Kodiak Island, Alaska, Geology, 14, 160-163, 1986.

Sarnthein, M., and R. Thiedemann, Toward a high resolution stable isotope stratigraphy of the last million years, OPP sites 658 and 659, off northwest Africa, Proc. Ocean Drill Prog. Sci. Results, 108, 167-186, 1989.

Scholl, D. W., Sedimentary sequences in the North Pacific trenches, in The Geology of Continental Margins, edited by C. A. Burk and C. L. Drake, pp. 493-504, Springer-Verlag, New York, 1974.

Scholl, D. W., Plate tectonics the predictor: The history of wonderments about subduction erosion and sediment subduction-A search for the missing, in Silver Anniversary Celebration of Plate Tectonics, edited by T. W. C. Hilde and R. H. Carlson, pp. 54-56, Geodynamics Research Institute, Texas A\&M University, College Station, 1987.

Scholl, D. W., and T. L. Vallier, Subduction and the rock record of Pacific margins, in Expanding Earth Symposium, edited by S. W. Carey, pp. 235-245, University of Tasmania, Hobart, Tasmania, Australia, 1981.

Scholl, D. W., and T. L. Vallier (Eds.), Geology and Offshore Resources of Pacific Island Arcs-Tonga Region, Earth Science Ser., vol. 2, 488 pp., Circum-Pacific Conference for Energy and Mineral Resources, Houston, Tex., 1985.

Scholl, D. W., M. S. Marlow, and A. K. Cooper, Sediment subduction and offscraping at Pacific margins, in Island Arcs Deep Sea Trenches and Back-Arc Basins, Maurice Ewing Ser., vol. 1, edited by M. Talwani and W. C. Pitman III, pp. 199-210, AGU, Washington, D. C., 1977

Scholl, D. W., T. L. Vallier, and G. Packham, Framework geology and resource potential of southern Tonga platform and adjacent terranes-A synthesis, in Geology and Offshore Resources of Pacific Island Arc-Tonga Region, Earth Sci Ser., vol. 2, edited by D. W. Scholl and T. L. Vallier, pp. 457-486, Circum-Pacific Council for Energy and Mineral Resources, Houston, Tex., 1985.

Scholl, D. W., T. L. Vallier, and A. J. Stevenson, Geologic evolution and petroleum geology of the Aleutian Ridge, in Geology and Resource Potential of the Continental Margin of Western North America and Adjacent Ocean Basins, Beaufort Sea to Baja, California, Earth Sci. Ser., vol. 6, edited by D. W. Scholl, A. Grantz, and J. G. Vedder, pp. 123-155, Circum-Pacific Council for Energy and Mineral Resources, Houston, Tex., 1987.

Scholl, D. W., M. N. Christensen, R. von Huene, and M. S. Marlow, Peru-Chile trench sediments and sea-floor spreading, Geol. Soc. Am. Bull., 81, 1339-1360, 1970.

Scholl, D. W., R. von Huene, T. L. Vallier, and D. G. Howell, Sedimentary masses and concepts about tectonic processes at underthrust ocean margins, Geology, 8, 564-568, 1980. 
Schweller, W. J., and L. D. Kulm, Extensional rupture of oceanic crust in the Chile Trench, Mar. Geol., 28, 271-291, 1978.

Schweller, W. J., L. D. Kulm, and R. A. Prince, Tectonics, structure, and sedimentary framework of the Peru-Chile trench, in Nazca Plate: Crustal Formation and Andean Convergence, edited by L. D. Kulm, J. Dymond, E. J. Dasch, D. M. Hussong, and R. Roderick, 349, Mem. Geol. Soc. Am., 154, 232-349, 1981.

Seely, D. R., P. R. Vail, and G. G. Walton, Trench slope model, in The Geology of Continental Margins, edited by C. A. Burk and C. L. Drake, pp. 249-260, Springer-Verlag, New York, 1974.

Seliverstov, N. I., Seismic Acoustic Studies in the Transition Zone (in Russian), 112 pp., Akad. Nauk CCCP, 1987.

Shi, Y., and C. Y. Wang, Pore pressure generation in front of the Barbados Ridge Complex, Geophys. Res. Lett., 12, 773-776, 1985.

Shi, Y., and C. Y. Wang, Pore pressure generation in sedimentary basins: Overloading versus aquathermal, J. Geophys. Res., 91, 2153-2162, 1986.

Shi, Y., and C. Y. Wang, Generation of high pore pressures in accretionary prisms: Inferences from the Barbados subduction complex, J. Geophys. Res., 93, 8893-8910, 1988.

Shipley, T. H., and G. F. Moore, Sediment accretion, subduction and dewatering at the base of the trench slope off Costa Rica: A seismic reflection view of the decollement, J. Geophys. Res., 91, 2019-2028, 1986.

Shipley, T. H., P. L. Stoffa, and D. F. Dean, Underthrust sediment, fluid migration paths, and mud volcanoes associated with the accretionary wedge off Costa Rica: Middle America trench, J. Geophys. Res., 95, 8743-8752, 1990.

Shouldice, D. H., Geology of the western Canadian continental shelf, Bull. Can. Petrol. Geol., 19, 405-436, 1971.

Shreve, R. L., and M. Cloos, Dynamics of sediment subduction, melange formation, and prism accretion, J. Geophys. Res., 91, $10,229-10,245,1986$.

Sloan, J. L., II, Cenozoic organic carbon distribution in the deep sea, M.S. thesis, 197 pp., Univ. of Miami, Miami, Fla., 1985.

Snavely, P. D., Jr., Tertiary geologic framework, neotectonics, and petroleum potential of the Oregon-Washington continental margin, in Geology and Resource Potential of Western North America and Adjacent Ocean Basins-Beaufort Sea to Baja, California, Earth Sci. Ser., vol. 6, edited by D. W. Scholl, A. Grantz, and J. G. Vedder, pp. 305-335, Circum-Pacific Council for Energy and Mineral Resources, Houston, Tex., 1987.

Snavely, P. D., Jr., and R. E. Wells, Cenozoic evolution of the continental margin of Oregon and Washington, U.S. Geol. Surv. Open File Rep., in press, 1991.

Snavely, P. D., Jr., R. von Huene, D. M. Mann, and J. Miller, The central Oregon margin, line WO76-4, seismic images of modern convergent margin tectonic structure, Am. Assoc. Petrol. Geol. Stud. Geol., 26, 26-27, 1986.

Southam, J. R., and W. W. Hay, Global sedimentary mass balance and sea level changes in The Sea, the Oceanic Lithosphere, vol. 7, edited by C. Emiliani, pp. 1617-1684, Wiley-Interscience, New York, 1981.

Spencer, A. M. (Ed.), Mesozoic-Cenozoic orogenic belts, Spec. Publ., Geol. Soc. London, 4, 809 pp., 1974.

Stem, C. R., Role of subduction erosion in the generation of Andean magmas, Geology, 19, 78-81, 1991.

Suess, E., et al., Ocean Drilling Program leg 112, Peru continental margin, Part 2, Sedimentary history and diagenesis in a coastal upwelling environment, Geology, 16, 939-943, 1988.

Tankard, A. J., and H. R. Balkwill (Eds.), Extensional tectonics and stratigraphy of the north Atlantic margins, Mem. Am. Assoc. Petrol. Geol., 46, 641 pp., 1989.

Taylor, S. R., and S. M. McLennan, The Continental Crust: Its Composition and Evolution, 312 pp., Blackwell, Oxford, 1985.
Tera, F., L. Brown, J. Morris, and I. S. Sacks, Sediment incorporation in island-arc magmas: Inferences from ${ }^{10} \mathrm{Be}$ Geochim. Cosmochim. Acta, 50, 535-550, 1986.

Thomburg, T. M., Seismic stratigraphy of Peru forearc basin, in Atlas of the Ocean Margin Drilling Program, Peru Continental Margin, Region VI, Mar. Sci. Int., vol. 9, edited by D. M. Hussong et al,, p 8, Woods Hole, Mass., 1985.

Thornburg, T. M., and D. L. Kulm, Sedimentation in the Chile trench: Depositional morphologies, lithofacies, and stratigraphy, Geol. Soc. Am. Bull., 98, 33-52, 1987.

Thorpe, R. S., P. W. Francis, and R. S. Harmon, Andean andesites and crustal growth, Philos. Trans. R. Soc. London, Ser A, 305-320, 1981.

Trehu, A. M., and W. H. Wheeler IV, Possible evidence for subducted sedimentary materials beneath central Califomia, Geology, 15, 254-258, 1987.

Veizer, J., and S. L. Jansen, Basement and sedimentary recycling-time dimension to global tectonics, J. Geol., 93, $625-643,1985$.

von Huene, R., Structural diversity along modem convergent margins and the role of overpressured pore fluids in subduction zones, Bull. Soc. Geol. France, 7, 207-219, 1984.

von Huene, R., Direct measurement of pore fluid pressure, leg 84; Guatemala and Costa Rica, Initial Rep. Deep Sea Drill. Proj., 84, 767-772, 1985.

von Huene, R., Seismic images of modern convergent margin tectonic structure, Am. Assoc. Petrol. Geol. Stud. Geol., 26, 60 pp., 1986.

von Huene, R., and R. Cullotta, Tectonic erosion at the front of the Japan convergent margin, Tectonophysics, 160, 75-90, 1989.

von Huene, R., and L. D. Kulm, Tectonic Summary of Leg 18 Initial Rep. Deep Sea Drill. Proj., 18, 961-976, 1973.

von Huene, R., and S. Lallemand, Tectonic erosion along the Japan and Peru convergent margins, Geol. Soc. Am. Bull., 102, 704-720, 1990.

von Huene, R., and $H$. Lee, The possible significance of pore fluid pressures in subduction zones, in Studies in Continental Margin Geology, edited by J. S. Watkins and C. L. Drake, Mem. Am. Assoc. Petrol. Geol., 34, 781-791, 1982.

von Huene, R. and J. Miller, Migrated multichannel seismic reflection records across the Penu continental margin, Proc. Ocean Drill. Prog. Initial Rep., 112, 109-124, 1988.

von Huene, R., and G. G. Shor, Jr., The structure and tectonic history of the eastem Aleutian Trench, Geol. Soc. Am. Bull., 80, 1889-1902, 1969.

von Huene, R., L. D. Kulm, and J. Miller, Structure of the frontal part of the Andean margin, J. Geophys. Res., 90, 5429-5442, 1985.

von Huene, R., J. Miller, M. Fisher, and G. Smith, An Eastern Aleutian trench seismic record, in Seismic Expression of Structural Styles, A Picture and Work Atlas, edited by A. W. Bally, Am. Assoc. Petrol. Geol. Stud. Geol., 3, 135-137, 1983.

von Huene, R., M. Langseth, N. Nasu, and H. Okada, A summary of Cenozoic tectonic history along the IPOD Japan trench transect, Geol. Soc. Am. Bull., 93, 829-846, 1982.

von Huene, R., et al., Ocean Drilling Program Leg 112, Peru Continental Margin, Part 1, Tectonic history, Geology, 16, 934-938, 1988.

Warren, P. H., Growth of the continental crust: A planetarymantle perspective, Tectonophysics, 161, 165-199, 1989.

Watkins, J. S., K. J. McMillen, B. S. Bachman, T. H. Shipley, J. C. Moore, and C. Augevine, Tectonic synthesis, Leg 66: Transect and vicinity. Initial Rep. Deep Sea Drill. Proj., 66, 837-864, 1982.

Wernicke, B., and B. C. Burchfiel, Modes of extensional tectonics, J. Struct. Geol., 4, 105-115, 1982. 
Westbrook, G. K., and M. J. Smith, Long decollements and mud volcanoes: Evidence from the Barbados Ridge complex for the role of high pore-fluid pressure in the development of an accretionary complex, Geology, 11, 279-283, 1983.

Westbrook, G. K., J. W. Ladd, P. Bruhl, N. Bangs, and G. J. Tiley, Cross section of an accretionary wedge: Barbados Ridge complex, Geology, 16, 631-635, 1988.

White, R. S., Deformation of the Makran accretionary sediment prism in the Gulf of Oman (north-west Indian Ocean), in Trench-Forearc Geology: Sedimentation and Tectonics on Modern and Ancient Active Plate Margins, edited by J. K. Leggett, pp. 357-373, Scientific, Boston, Mass., 1982.

White, R. S., and K. E. Louden, The Makran continental margin: Structure of a thickly sedimented convergent plate boundary, in Studies in Continental Margin Geology, edited by J. S. Watkins and C. L. Drake, Mem. Am. Assoc. Pet. Geol., 34, pp. 499-518, 1982.

White, W. M., and B. Dupré, Sediment subduction and magma genesis in the Lesser Antilles: Isotopic and trace element constraints, J. Geophys. Res., 91, 5927-5941, 1986.

Wolf, L. W., and A. R. Levander, Upper crustal structure of the accreted Chugach Terrane, Alaska, J. Geophys. Res., 94, 4457-4466, 1989.

Worsley, T. R., and T. A. Davies, Sea-level fluctuations and deep-sea sedimentation rates, Science, 203, 455-456, 1979.

Yamazaki, T., and Y. Okamura, Subducting seamounts and deformation of overriding forearc wedges around Japan, Tectonophysics, 160, 207-229, 1989.
Yorath, C. J., Petroleum potential of the Canadian Pacific continental margin, in Geology and Resource Potential of the Continental Margin of Western North America and Adjacent Ocean Basins-Beaufort Sea to Baja, California, Earth Sci. Ser., vol. 6, edited by D. W. Scholl, A. Grantz, and J. G. Vedder, pp. 283-304, Circum-Pacific Council for Energy and Mineral Resources, Houston, Tex., 1987.

Yorath, C. L., A. G. Green, R. M. Clowes, A. S. Brown, M. T. Brandon, E. R. Kanasewich, R. D. Hyndman, and C. Spencer, LITHOPROBE, southern Vancouver Island: Seismic reflection sees through Wrangellia to the Juan de Fuca plate, Geology, 13, 759-762, 1985.

Yoshii, T., A detailed cross-section of the deep seismic zone beneath north-eastern Honshu, Japan, Tectonophysics, 55, 349-360, 1979.

Ziegler, A. M., S. F. Barrett, and C. R. Scotese, Palaeoclimate, sedimentation and continental accretion, Philos. Trans. $R$. Soc. London, Ser. A, 301, 253-264, 1981.

D. W. Scholl, U. S. Geological Survey, Menlo Park, CA 94025.

R. von Huene, GEOMAR, Kiel, D-2300 Kiel 14, Germany. 